Florida International University FIU Digital Commons

$3-5-2013$

\title{
Empire's Children: Soviet Childhood in the Age of Revolution
}

Loraine de la Fe

Florida International University, 1de1002@fiu.edu

DOI: $10.25148 /$ etd.FI13040301

Follow this and additional works at: https://digitalcommons.fiu.edu/etd

\section{Recommended Citation}

de la Fe, Loraine, "Empire's Children: Soviet Childhood in the Age of Revolution" (2013). FIU Electronic Theses and Dissertations. 812. https://digitalcommons.fiu.edu/etd/812

This work is brought to you for free and open access by the University Graduate School at FIU Digital Commons. It has been accepted for inclusion in FIU Electronic Theses and Dissertations by an authorized administrator of FIU Digital Commons. For more information, please contact dcc@fiu.edu. 


\title{
FLORIDA INTERNATIONAL UNIVERSITY
}

Miami, Florida

\section{EMPIRE'S CHILDREN: SOVIET CHILDHOOD IN THE AGE OF REVOLUTION}

\author{
A dissertation submitted in partial fulfillment of \\ the requirements for the degree of \\ DOCTOR OF PHILOSOPHY \\ in \\ HISTORY \\ by
}

Loraine de la Fe

2013 
To: Dean Kenneth G. Furton

College of Arts and Sciences

This dissertation, written by Loraine de la Fe , and entitled Empire's Children: Soviet Childhood in the Age of Revolution, having been approved in respect to style and intellectual content, is referred to you for judgment.

We have read this dissertation and recommend that it be approved.

Tom Ewing

Aurora Morcillo

Bianca Premo

Patricia Price

Rebecca Friedman, Major Professor

Date of Defense: March 5, 2013

The dissertation of Loraine de la Fe is approved.

Dean Kenneth G. Furton

College of Arts and Sciences

Dean Lakshmi N. Reddi

University Graduate School

Florida International University, 2013 


\section{ACKNOWLEDGMENTS}

This project has undergone several phases paralleled to Soviet History. It began with a revolutionary fervor and zeal followed by an arduous period of stagnation. After a few perestroikas, it ended with an opening or glasnost. The long journey was supported over many years by various institutions, colleagues, friends, and family.

The research for this dissertation was conducted with the support of U.S. Department of State, Title VIII Research Grant, Florida International University Dissertation Evidence Acquisition Fellowship and Dissertation Year Fellowship, various institutions at the University of Illinois, Champaign-Urbana, Russian, East European and Eurasian Center, the University of Pittsburgh Slavic Language and Literatures, and the Wolfsonian-FIU Museum.

The idea of writing on the history of Soviet Childhood sparked during a conversation with my then Russian teacher and now sister, Zayana Dzhimbinova, who in addition to teaching the language, taught me about a hidden world within Russia's borders.

In Russia, I was grateful to receive much support and guidance from the scholars and staffs of many archives and libraries, including Natsional'nii Arkhiv Respubliki Kalmykiia (NARK), Natsional'nii Musei Respubliki Kalmykiia (NMRK), Tsentral'nii Arkhiv Goroda Moskvii (TsAGM), Tsentral'nii Arkhiv Moskovskoi Oblasti (TsAMO). I am indebted to $m y$ families: Dzhimbinov- Alexey, Ludmilla, Viktoria-- and Merkulov-Delya, Marina, Vladimir-- for opening their hearts and homes to me in Kalmykia and Moscow. I would also like to thank Olga Vainshtein for her generous time 
and support in this project. In Spain, I would like to thank the archivists in the Archivos de la Guerra Civil in Salamanca for their warm hospitality and guidance.

My dissertation would not be what it is today without the friendship, support and guidance of so many individuals, including my incredibly patient dissertation committee, Tom Ewing, Bianca Premo, Aurora Morcillo, and Patricia Price. I am also thankful for the individuals, friends, and mentors who gave so much of their time to make this project successful: Kenneth Lipartito, Gwyn Davies, Sherry Johnson, Nikolai Harsanyi, Lara Kriegel, Mark D. Szuchman, Noble David Cook, Victor Uribe, Amanda J. Snyder, Carolina Zumliaglini, Paula de la Cruz-Fernandez, Erika D. Edwards for your amazing guidance, Olga Klimova of University of Pittsburgh for accompanying me on my first Russian Archival visit, Joseph Lenkart for all your help at the Slavic Library at University of Illinois, and Andrew R. Lazo for your willingness to become an honorary historian and read my work with a critical eye for so many years, and the Department of History at Florida International University.

Finally, I would like to thank my family Aida, Ernesto, David and Elvis de la Fe, Pilar Ros, Carmen Vallejo-Ros and Nona Williams Lazo who have always unconditionally supported me in my crazy adventures. Last but not least, I would especially like to thank my confidant, advisor, and mentor, Rebecca Friedman, not only for her time, but her generous spirit and soul that inspired me to become what I am today.

In transliterating Russian texts, I have used the Library of Congress system, except in commonly known spellings of names. 
(C) Copyright 2013 by Loraine de la Fe

All rights reserved. 


\section{ABSTRACT OF THE DISSERTATION \\ EMPIRE'S CHILDREN: SOVIET CHILDHOOD IN THE AGE OF REVOLUTION \\ by}

Loraine de la Fe

Florida International University, 2013

Miami, Florida

Professor Rebecca Friedman, Major Professor

Ideas of childhood and citizenship stood at the center of the Soviet Union's empire-building project during the 1920s and 1930s. After the 1917 Revolution the Bolsheviks were faced with the challenge of establishing a new state structure and governing a vast territory inherited from its tsarist predecessor. In the early years of the Soviet project, new leaders enlisted a cadre of professionals tasked with not only creating the norms of childhood and the everyday, but also implementing policies to modernize habits and values of the empire's younger citizens.

To understand how children became a prime focus of Soviet imperial and ethnocultural politics, my dissertation employs discourse analysis and compares the ways in which Soviet imperial policies were implemented in two ethnically different regions: the Buddhist Republic of Kalmykia as the colonial case study and Moscow as the Metropole. The current project examines newspapers, treatises, and inspectors' reports over the span of twenty years. It finds that the Bolsheviks' initial values and discourses in the realm of children's education, health, leisure and nutrition, all which were scientifically designed to transform children into ideal Soviet and modern citizens, changed over time as a result 
of the competing ideologies among local elites and the challenges they faced while intervening in children's everyday lives.

The most significant conclusion in this dissertation reveals that, contrary to previous scholarly arguments, the modernization projects that took place in Moscow and Kalmykia were more similar in the challenges and outcomes that local officials faced when implementing state policies. 


\section{TABLE OF CONTENTS}

CHAPTER

PAGE

I. INTRODUCTION: IMAGINING THE EVERYDAY SOVIET CHILD ........1

II. THE CHILD COMPASS: SPACE AND PLACE IN THE SOVIET IMAGINATION .34

III. A CHILD'S HEALTH IS DEPENDENT ON DISTORTIONS OF THE BYT: THE CHILD'S BODY AND HYGIENE IN EARLY SOVIET RUSSIA ......69

IV. SOCIALIZATION IN THE LUNCHROOM: CHILDREN'S FOOD CONSUMPTION IN EARLY SOVIET RUSSIA.........................................103

V. INTO THE LIGHT: LANGUAGE AND CULTURAL ENLIGHTENMENT

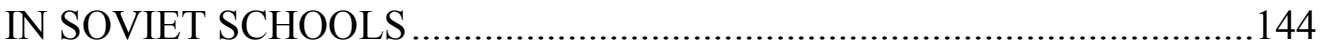

VI. CONCLUSION: BORDERLESS EMPIRE: SOVIET CHILDHOOD AND THE EVERYDAY IN THE GLOBAL CONTEXT .....................................186

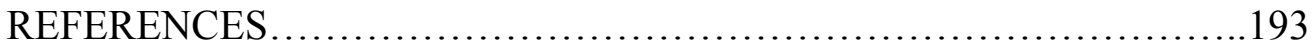

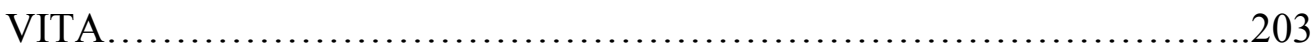




\section{LIST OF FIGURES}

\section{FIGURE}

PAGE

1. Map of Russia..................................................... 23

2. Girl Playing Instrument Wearing Traditional Kalmyk Clothing .........................82

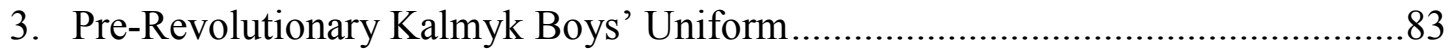

4. Early Soviet Kalmyk Boys'

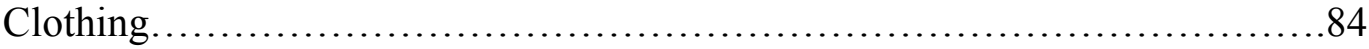

5. Example of Kalmyk and Russian Children in Pioneer Uniform ..........................86

6. Illustration of Men and Women Working .................................................. 103

7. Example of Outdoor Stolovaia in Kalmyk Children's Institution ......................141

8. Example of Outdoor Stolovaia in Moscow Kindergarten.................................141

9. Example of Kalmyk Language Geography Textbook in Latin Characters..........160

10. Example of Kalmyk Language Literary Textbook Printed in Cyrillic ...............161 


\section{LIST OF TABLES}

TABLE

PAGE

1. Average Daily Food Intake in Kindergartens/ Per child ............................................................... 116

2. Food Distribution in Kalmyk Children's Homes 130

3. Food Distribution in Moscow Children's Institutions According to Age Group 137

4. Average Number of Hours Departmentalizing Kalmyk Education, 1923 _..........166

5. Average Scores According to Age Group in Privolga School, 1931-1932 .........172 


\section{CHAPTER I: IMAGINING THE EVERYDAY SOVIET CHILD}

The August 231929 edition of the youth journal Komsomol'skaia Pravda declared that the Soviet government was on the brink of developing "a Five-Year Plan of Childhood." Like its official counterpart which was designed to revamp and modernize the economy and social conditions throughout the Soviet Union, the particular plan was designed to strengthen "comrade children's discipline, strive for knowledge" and provide Soviet children opportunities to experience a common privileged childhood unlike anywhere else in the world. These promises were proclaimed in Stalin's happy childhood campaign, in which the State took responsibility for the welfare of children and professed to them that only in the Soviet Union could they experience a happy childhood, free from the burdens of life under capitalist countries, including child labor. The happy childhood declaration accompanied what was the first All-Union Pioneer conference held in Moscow that same week. During the conference, children-- or delegates, as they were referred to in the article — traveled to Moscow from all over the Soviet Union, including: Leningrad, the North Caucasus, Tartar Republic, Urals, Lower Volga, the Republic of Germans around the Volga, Kalmykia, Siberia, and Belorussia, to congregate in the Kremlin. Children from various parts of the Soviet Union were interviewed after their attendance to the first international children's conference boasting about Moscow's hospitality and their "gratitude towards Moscow Pioneer children and their parents."1

Against the backdrop of the Kremlin-- a place imbued with an icon of great imperial power-- children from all over the Soviet Union, from various ethnic backgrounds gathered to celebrate this one victory towards the revolutionary

\footnotetext{
1 “Razrabotaem detskuiu piatletku," Komsomomskaia Pravda, August 23, 1929, p. 2.
} 
march forward. Although this conference was not established until over a decade after the revolution, as early as 1918 Soviet pedagogues and pediatricians undertook immediate measures in developing new programs and routines that would transform the everyday lives of the young inhabitants of the new empire and usher them into a Soviet, more 'modern' age.

My dissertation examines the ways in which Soviet officials used children and discourses about childhood — through myths and polices - to foster the construction of the newly gained Imperial Russian territory after the Revolution in 1917. It focuses on the state-led children's institutions from children's homes, schools, kindergartens, and recreational camps as the backdrop to explore how both children from different ethnic backgrounds, including ethnic Russians and non-Russians (or those of non-Slavic origin) encountered and experienced these changes in their everyday lives through manipulation of their spaces, their bodies, their eating habits, and their education as well as language acquisition. Each of these facets of children's everyday lives was mandated by official state treatises, and was overseen by national, regional, and local inspectors throughout the Soviet empire.

To understand how and why children became a prime focus of Soviet imperial and ethno-cultural political projects, my study compares two distinctive regions of the Soviet Union: Moscow and Kalmykia. The first case study is the Republic of Kalmykia, a politically autonomous region bordering the North Caucuses. Kalmykia is a particularly useful case study because of its long history of confrontation with Russian Tsarist politics and its unique Mongolian-ethnic and Buddhist religious demographic. Anglo scholars have considered this interaction between ethnic Russians and Kalmyks in the eighteenth 
or nineteenth-century context, but not in the Soviet period. ${ }^{2}$ In order to compare the revolutionary progress made in children's lives, the city of Moscow serves as a comparative focus to measure the consistencies, contradictions and challenges faced when implementing official strategies (ones that claimed to would transform the individual child from a 'backwards' creature to a 'modern' subject), common Soviet identities - as official culture mandated all children were entitled—and expected— to do. WHY CHILDHOOD AND EMPIRE IN THE SOVIET CONTEXT?

My dissertation contributes to the scholarship on the Soviet social experiment history by examining the early Bolshevik project of transforming the individual through the prisms of empire, the everyday, childhood, and the striving towards modernity. By using the lens of childhood to compare imperial processes in the metropole and periphery, a new narrative of Soviet imperialism emerges. ${ }^{3}$ Many scholars, who focus on factors of revolutionary transformations in various contexts of space, education, and especially hygiene, argue that these processes of modernization were only experienced in the Soviet imperial capital, Moscow. My dissertation highlights that this was not necessarily the case. In fact, the experiences of children's everyday lives in Kalmykia and Moscow suggest that children both on the margins and in the center had common, rather than disparate, interactions with state officials and their policies. Therefore, these factors such as implementation of policies, material shortages and everyday challenges from the local population, expose a more unified history than a skewed one that

\footnotetext{
${ }^{2}$ Michael Khodarkovsky, Where Two Worlds Met: The Russian State and the Kalmyk Nomads, 1600-1771 (Ithaca: Cornell University Press, 1992).

${ }^{3}$ Here, I use the term metropole to connote the imperial seat of governance, as historians of other imperial systems employ in their studies.
} 
overemphasizes how the revolutionary drive forward was mostly a Moscow (or Leningrad) phenomenon. In other words, Soviet officials' attempts in implementing state or government-led programs for children were equally challenging and successful, and were not a matter of "Sovietized vs. Backwater" outcomes in terms of the capital's relationship with the periphery.

\section{EMPIRE}

During the initial days of the Bolshevik's ascendency to power, Vladimir Lenin referred to the Tsarist Empire as the 'Prison of the Peoples. ${ }^{4}$ His metaphor served as the basis for the Soviet Party-State's imperial propaganda campaign. In fact, by portraying itself as the liberator of formerly oppressed peoples, the Soviet Party-State declared itself as anti-imperialist. ${ }^{5}$ The Soviet Union's initial 'anti-imperial' projects would involve what revisionist historians identify as the 'nationalities campaign'—a pseudo-Federalist polity that allowed the various cultures and ethnicities across Soviet territory the right to national self-determination, with the term 'nationalities' equating to the concept of 'ethnicity'. ${ }^{6}$ However, in practice, the Soviet Union was in essence an empire, with Moscow as the central location of governance, which imposed its projects and policies in non-ethnically Russian regions. Yet, by allowing the various ethnic groups to gain ethnic awareness, over time, it also produced a sense of national consciousness, which was a

\footnotetext{
${ }^{4}$ Helene Carrere d'Encausse, Decline of an Empire: The Soviet Socialist Republics in Revolt trans. Martin Sokolinsky (New York: Newsweek Books, 1980), 36.

${ }^{5}$ Yuri Sezkline, Arctic Mirrors: Russia and the Small Peoples of the North (Ithaca: Cornell University Press, 1994.

${ }^{6}$ Terry Dean Martin, Affirmative Action Empire: Nations and Nationalism in the Soviet Union, 1923-1938 (Ithaca: Cornell University Press, 2001).
} 
major factor in the dissolution of the Soviet Union, as the various ethnic territories cried out in support of national and political autonomy.

The Bolsheviks' "new" Soviet imperialism distinguished itself from its (Russian) predecessor and Western European models of imperial rule by allowing the newlycreated nations under the Soviet Union some political autonomy, and a right to practice its governance, including its own publications in its native language. Lenin and his cohort stipulated that a sense of ethnic autonomy could flourish as long as it did not interfere politically with the Bolshevik-Party rule and its orders from Moscow.

Even though the rhetoric was distinct from Western models of colonization, the strategies were not. In fact, Bolsheviks drew inspiration from Western colonial projects, particularly in the social sciences, using ethnography and statistics —including census records-- to draw the USSRs internal borders. ${ }^{7}$ Another notable distinction of Soviet imperialism is its peculiar periodization: while the early to mid-twentieth century witnessed the decline of Western imperialist systems, the Soviet Union was revamping its own in full force.

These tactics have led more scholars since the fall of the Berlin Wall to challenge Cold War studies on the Soviet Union as a totalitarian and coercive force and argue that it was a rather 'benign empire. ${ }^{8}$ Yet, even these more recent scholars cannot ignore the

\footnotetext{
${ }^{7}$ Francine Hirsch, Empire of Nations: Ethnographic Knowledge and the Making of the Soviet Union (Ithaca: Cornell University Press, 2005). Another influential study that reveals the fluctuations in drawing Soviet borders is Kate Brown's, A Biography of No Place: From Ethnic Borderland to Soviet Heartland. (Cambridge: Harvard University Press, 2004). In her study, Brown explores the resistance of the powerless peoples in the borderlands of Soviet Poland and Ukraine, how they manipulated Soviet policy and taxonomy of nationalities to shift 'identity' to work in their favor during the period of re-defining borders and "acceptable" nationalities.

${ }^{8}$ Richard Pipes, Russia Under the Old regime (New York: Charles Scribner \& Sons, 1974). Richard Pipes The Formation of the Soviet Union: Communism and Nationalism 1917-1923 (Cambridge: Harvard
} 
fact that the 1930s, however, saw a break with the Bolsheviks' initial toleration policies of the nationalities campaign. In 1934, Party-leader Joseph Stalin initiated imperial policies, that in some ways resembled the tsarist era. For example, although the tsarist regime was relatively tolerant of its ethnically diverse subjects, it still promoted Russian Orthodoxy and increasingly over the course of the $19^{\text {th }}$ century, with the influence of Darwinism, Russians saw themselves as racially superior. ${ }^{9}$ Stalin's policies of intense Russification in schools and particularly in the growth of Russian- nationalist patriotism immediately before the Second World War, (or as older Bolshevik leaders referred to Russian chauvinist ) became increasingly synonymous with Soviet identity. In addition to rehabilitating Russian national figures such as the legendary hero Alexander Nevskii and Peter the Great, Stalin, in 1938, mandated that all schools in the Soviet empire and government apparati must be held in the Russian language. Although native language continued to be taught at schools, Russian did become the most prominent language of

University Press, 1970). In his study, The Formation of the Soviet Union: Communism and Nationalism 1917-1923, Richard Pipes argues that the Soviet government was even worse than its imperial predecessor in granting minority rights, by destroying independent parties and tribal rights. Recent studies have challenged this view of the Soviet government as a 'breaker of nations. Another influential and important study on pre-Revolutionary imperialism is Wayne Dowler, Classroom and Empire: The Politics of Schooling Russia's Eastern Nationalities, 1860-1917 (Montreal: Mc Gill-Queen's University Press, 2001). In his study, Dowler looks at the relationship between ethnic identity and modernization. He states that before the serf emancipation of 1861 the bureaucratic Imperial government only focused on elite children's schooling, preparing them for careers in government. He adds that it was not until the early twentieth century that the ministries devised plans of universal compulsory education across the empire, and thus continued with its literacy campaign to assimilate and nationalize the ethnic minorities. Yet, Dowler argues that national self-consciousness was unevenly developed throughout the empire, as many ethnic minorities resisted the intrusion of Russian bureaucratic education. In addition, Russian pedagogues faced increased competition with the rise of Islam and Arabic literacy throughout the empire. Adrienne Lynn Edgar, Tribal Nation: The Making of Soviet Turkmenistan (Princeton: Princeton University Press, 2004). Edgar's Tribal Nation is a revisionist study arguing that the Soviet Union, in promoting cultural identity and nationalist values was actually a maker of nations. She illustrates the way in which the Soviet government both succeeded in garnering support from local urban elites, who had their own visions of Turkmen nationalism and yet failed to radicalize primarily Muslim peasants into communist ideology.

${ }^{9}$ Wayne Dowler, Classroom and Empire: The Politics of Schooling of Russia's Eastern Nationalities, 1860-1917 (Montreal: McGill-McQueen's University Press, 2001), 10. 
the Soviet system. Whether the Soviet Empire was 'coercive,' as claimed by Cold War historians, or 'benign,' as described by revisionists, the Soviet colonial officials still met significant resistance from ethnic minorities on the ground. However, not all national minorities resisted the Russification policies as they saw the acquisition of Russian language as a way to escape the 'ghetto of nationality.' ${ }^{10}$ While this study uses the term 'Russification' to describe the increasing cultural dominance of Russian language in nonRussian regions, it understands 'Sovietization' as a different cultural phenomenon that encompasses Leninist-Marxist notions of collectivity, love of work, and atheism.

In his study on the Soviet campaign against the seclusion of women in Stalinist Central Asia, Douglas Northrop challenges the revisionist version of Soviet selfperception as anti-colonial. Indeed, the Soviets perceived themselves as well as Slavic peasants as racially and morally superior to their Asiatic counterparts. Because of the lack of class differences, Northrop argues, Soviet authorities substituted gender for class inequality in this region in order to promote their ideologies and campaigns. Yet, their campaigns for women's liberation were not widely accepted and were resisted by local populations. These events reveal how the Soviet state and its political culture, was not fixed or all-powerful, but its ideas rather were constantly contested, changed, and redefined. $^{11}$

\footnotetext{
${ }^{10}$ Richard Grigor Suny, The Soviet Experiment: Russia, the USSR and the Successor States (Oxford: Oxford University Press, 2011).

${ }^{11}$ Douglas Northrop, Veiled Empire: Gender and Power in Stalinist Central Asia (Ithaca: Cornell University Press, 2004). Northrop's study examines how the Uzbek population in general and how women in particular resisted state policies. While the veil signified oppression for the Soviet state, Uzbek women saw it as a way to resist their colonial oppressors. In the end, Northrop finds that the Soviet state failed in transforming the region in the 1930s, at the height of Soviet power, and it was not until after WWII that significant cultural changes took place, including the assimilation of Uzbek women into Soviet culture and political practices.
} 


\section{POST-SOVIET SCHOLARSHIP ON KALMYKIA AND NATIONALITIES STUDIES}

Studies on nationalities and ethnic minorities in the late Soviet period were dominated by the mono-ideological Marxist theory, since it was the only one accepted by the Communist Party. With the fall of the Soviet Union, national minorities studies, especially those in Kalmykia, became more nationalist (in the nineteenth-century statebuilding sense) in their orientation and openly defiant towards the Soviet regime. PostSoviet scholarship served a political purpose, especially those in Kalmykia creating movements such as "My Oirati" ("we are Oirats") to assert their cultural and traditional independence from Russian hegemony — all of these of course were in the broader postSoviet phenomenon of kul'turnoe stroitel 'stvo (literally culture building). ${ }^{12}$

Following the nationalist discourse of the post-Soviet era, scholars began to narrow their focus from a general study of Kalmyk history and culture towards education, particularly in the late 1990s. Late twentieth-century scholars examine the origins of the Kalmyk educational system in connection with the historical development of the Kalmyk peoples. For scholars such as A.B. Pan'kin, the purpose of studying nationalities schools is to "fulfill the needs of the current educational system," which at the time was still in transition from the fall of the Soviet Union. ${ }^{13}$ According to Pan'kin, the Kalmyk integration educational system serves as the model for all nationality schools in the Russian Federation. Current Kalmyk scholars have revised their view of the

\footnotetext{
${ }^{12}$ U.E. Erdiniev and K.N. Maksimov, Kalmyki:Istoriko-etnografichesckie ocherki (Elista: Kalmytskoe Knizhnoe Izdatel'stvo, 2007), 3. Oirat is the Mongolian term for Kalmyks, while the term Kalmyk itself derives of Turkish origin.

${ }^{13}$ A. B. Pan'kin, Obrazovanie dlia Kalmykov: Istoki, realti, perspektivy (Elista: Kalmytski Gosudarstvenny Universitet, 1997), 8-9. Also see E.V. Sartikova, Obrazovanie Kalmykii istoki i stanovlenie (Elista: Dzhangar, 2000).
} 
developments of the Soviet educational system in Revolutionary Kalmykia without the constraints of Soviet censorship, and have focused on the repressive nature of the Soviet schools and their impact on the destruction of Kalmyk language and culture. In her study, E.V. Sartikova divides the history of the Soviet Kalmyk school system into three phases, in which she classifies the most devastating period under Lenin - because of the destruction of Kalmyk culture. ${ }^{14}$ She compares the destruction of Kalmyk culture to the similarities of the Cultural Revolutions in other nations, including Ukraine and Armenia. Yet, Sartikova identifies the Stalinist period as catastrophic, in particular because of the forced assimilation into Russian culture to remedy cultural backwardness and modernize the region, as well as the deportation of the Kalmyk peoples to Siberia in the 1940s. My work, building on the findings of scholars such as Sartikova, demonstrates not only the impacts of state polices but also how indigenous populations had a profound impact on colonial practices.

\section{THE EVERYDAY}

Taking my queues, in part, from Northrop, the current dissertation focuses on children in Kalmykia and Moscow. The study highlights the importance of the everyday — or the practices and rituals of daily life-- which is the most useful category of analysis in understanding the transformation of children's lives from the tsarist regime to the Soviet in the context of empire building. Since the policy makers are the ones who reached decisions, wrote tracts, laws, and mandates, children's voices are oft times out of reach when examining norms and experiences of childhood, especially those in nonethnically Russian territories. The vantage point of the mundane and daily life will not

${ }^{14}$ E.V. Sartikova, Razvitie shkol'nogo obrazovaniia v Kalmykii v XX veke (Elista: Kalmytskogo Instituta Gumanitarykh Issledovanyi, 2008), 10. 
only illuminate the actions of Bolsheviks and professionals (child care specialists), but also provide a deeper sense of how their decisions and policies affected children on the ground level.

The history of the everyday or Alltagsgeschichte aids historians in going beyond the grand narrative of political history by looking at how both politics and culture mutually shaped and influenced each other. The result is often a more dynamic picture of interaction among official and unofficial forces in society, rather than a top-bottom approach. ${ }^{15}$ The study of the everyday (alltageschichte) emerged from post-War West German scholarship, notably by the work of Alf Ludtke who developed and refined the sociological concept of everyday life as a way to understand how the 'silent actors or kleine leute - little people' were agents in larger socio-political projects, especially in Nazi-era Germany. ${ }^{16}$ Closely following Ludtke, Michel de Certeau's L'invention $d u$ quotidian, The Practice of everyday life explores people's logic in their everyday practices, especially in consumption, and their passivity. ${ }^{17}$

Post-Soviet historians also have adopted the concept of the everyday in order to understand the relationship between the state and society through daily practices and

\footnotetext{
${ }^{15}$ Geoff Ely, "Forward", The History of Everyday Life: Reconstructing Historical Experiences and Ways of Life, ed. Alf Ludtke Trans. William Templer (Princeton: Princeton University Press, 1995).

${ }^{16}$ Alf Ludtke, "Introduction: What is the History of Everyday Life and Who are its Practitioners?" The History of Everyday Life: Reconstructing Historical Experiences and Ways of Life, ed. Alf Ludtke Trans. William Templer (Princeton: Princeton University Press, 1995).

${ }^{17}$ Michel de Certeau, The Practice of Everyday Life, trans. Steven F. Rendall (Berkeley: University of California Press, 1984), 213-14. One example of De Certeau's methods is to interpret an individual's act of choice as an active and not passive action He argues the same when an individual is engaged the act of reading by stating, that "to read is to wander through an imposed system," which makes an individual a producer by transforming texts. For more on how the everyday influences culture in an interdisciplinary approach please see Markus Thiel and Rebecca Friedman, "Introduction: Culture and Narratives of Transnational Belonging," European Identity and Culture: Narratives of Transnational Belonging, eds. Rebecca Friedman and Markus Thiel (Burlington: Ashgate Publishing, 2012), 1-16.
} 
habits of ordinary citizens. However, in the Soviet-Russian context, everyday life, also known as the untranslatable term byt, takes on a distinctive cultural characteristic, that also infers the mundane, routinization of life and pragmatism in terms of 'getting by' the system through the black market—particularly under the Stalin-era. Svetlana Boym's work Common Places remains until today the most influential work on the everyday in Soviet and even post Soviet scholarship. ${ }^{18}$ In the Soviet case, these concepts are pervasive, particularly with the official discourses of collective work and the practicality or policies of shared or collective housing, laboring, and farming. Boym adds another layer to the notion of byt - that of bytie which is understood as the more spiritual being, a thought prominent among Russian intellectuals. Bytie combines the binary notion of the "real life" and "everyday life" in which the former is the spiritual, and the latter connotes the existence or mundane life. ${ }^{19}$ While the concept of byt is understood and used throughout this dissertation, primarily because Bolshevik officials and pedagogues identify this term in the sources, this dissertation does not use the term bytie itself. Inspectors' reports and treatises for instructors promote child purity in terms of discipline, thought, and hygiene, but the term bytie is absent in the sources. I hypothesize this is the case since bytie holds a rather supernatural connotation that would conflict with Soviet ideologies of materialism and structure.

My study of the everyday in two Russian communities, from 1917 to 1939, is profoundly impacted by the series of perpetual crises that marked the age: starting with

\footnotetext{
${ }^{18}$ Svetlana Boym, Common Places: Mythologies of Everyday Life in Russia (Cambridge: Harvard University Press, 1994), 35-40.

${ }^{19}$ Boym, Common Places, 29.
} 
the Revolution, Civil War, Collectivization (forced acquisition of peasant grain), constant food and material shortages, as well as the Terror or purges of party members, school, teachers and anyone associated with 'class enemies,' and the coming of war. Since it can be argued that the early revolutionary period was a stage of constant crisis in Soviet history, it is difficult to separate the everyday from crisis, which allows us to view how the Bolsheviks, through official discourse and in propaganda, and intervention in the population's everyday life, created a semblance of stability in the routine of learning, hygienic habits and eating, especially for children during a volatile period. ${ }^{20}$

A discursive analysis on Soviet official rhetoric helps us see the ordinary within the extraordinary. Several Soviet historians have examined the ways in which official discourses have been interpreted, practiced, and manipulated by ordinary people as a form of pragmatism. One example of this is Sheila Fitzpatrick's notion of the Homo Sovieticus, or self- fashioning as ideal Soviet citizen, as a method of survival, access to goods, and gain opportunities offered by the state. ${ }^{21}$ These concepts of the official culture of self-fashioning were-- in a sense-- combined with Michel Foucault's analysis of the self in the modern world, where the state's power takes a different form by using scientific, modern methods including surveillance and categorizations, as a way to keep its population in order and disciplined. ${ }^{22}$

By no means does this study suggest that the State is all-powerful and that the population was crippled under the watchful eye of the CHEKA or NKVD ( Soviet secret

\footnotetext{
${ }^{20}$ For more on everyday and crisis see: Olga Shevchenko, Crisis and the everyday in Postsocialist Moscow (Bloomington and Indianapolis: Indiana University Press, 2009).

${ }^{21}$ Fitzpatrick, Everyday Stalinism, 1999.

${ }^{22}$ Michel Foucault, Discipline and Punish: The Birth of the Modern Prison trans. Alan Sheridan (New York: Vintage Books, 1997).
} 
police organizations). My study of official discourse combined with the vantage point of the everyday in the imperial context illuminates the ways in which the actions of everyday actors, agents, and children were in many ways beyond the Communist Party's control or reach, whether in Moscow itself, or in the periphery, as the subsequent chapters will show.

The combination of empire and microhistorical case studies of children's lives provides a deeper understanding of the workings of Soviet imperial educational and child care policies, and the ways in which they were instrumental into constructing the ideal socialist state. The official discourses of Bolshevism, such as work, collectivity, and modernity also included praises of youth that were synonymous with the new state. Soviet scholars argue that both the state and the population had an impetus to recreate or transform themselves into new citizens, and as we shall see, the same citizenship-building projects applied to children. Looking at the everyday sheds light to a group of people who are normally left unheard. While there is little access to children's contemporary diaries or writing (though historians have acquired retrospective accounts), by looking at official discourses on childhood and reading inspectors' notes and their actions, we can glean a sense of children's experiences, lives, and motivations or even rejections of becoming Soviet citizens.

\section{CHILDREN AND CHILDHOOD}

The construction of a 'new childhood' in the Soviet Union and the changes in children's everyday lives was possible through the creation of schools, parks, and material goods made specifically for children's consumption. My dissertation distinguishes between childhood, as a set of normative discourses and practices, and 
children, as historical actors in their own right. By examining Soviet official propaganda, journals, children's books, textbooks and other ephemera, this dissertation finds the ways in which Bolshevik child specialists devised and created an imagined distinctively Soviet childhood. Inspectors' reports, children's diaries and memoirs provide insight to the ways in which children acted within these established or imagined set of practices.

The Revolutions in the early decades of the twentieth century brought significant changes in both narratives of childhood and children's lives. The 1917 Revolution caused a shift in child care from the private organizations that existed in the tsarist regime, to the state institutions. During this era of transformation, the Soviet propaganda, state officials and school inspectors claimed that it was the only nation in the world to achieve ideal conditions for children. The aim was to convince children of their 'Happy Childhood' in the Soviet Union by producing various forms of literature, fiction, nonfiction, children's journals and school curricula and activities. ${ }^{23}$ These materials aimed to teach children how to become an ideal Soviet citizen and reminded them that they were future builders of the Soviet state and communism, thus combining notions of modernization and childhood. With the creation of new institutions and other modernizing projects, in official discourses, the Bolsheviks often boasted to children about the new modern era that the Soviet Union was entering. The creation of childhood per se is not particular to the Russian or Soviet case but was concurrent to pre-World War I and interwar trends of child care. ${ }^{24}$

\footnotetext{
${ }^{23}$ Lisa Kirschenbaum, Small Comrades: Revolutionizing Childhood in Soviet Russia, 1917-1932 (New York: Routledge, 2001).

${ }^{24}$ Evgeny Steiner, Stories for Little Comrades: Revolutionary Artists and the making of Early Soviet Children's Books. Trans. Jane Ann Miller (Seattle: University of Washington Press), 1999; Marina Balina, "Creativity Through Restraint: The Beginnings of Soviet Children's Literature" In Russian Children's
} 
In probably the most influential and seminal work on childhood in European history-- Centuries of Childhood--Philippe Ariès traces the emergence of the categorical life stage childhood as a transition between medieval France towards the ancièn regime (in the seventeenth century). Through his work, the understanding of childhood becomes a separate set of discourse that evolves from cultural and social changes rather than as a biological category. ${ }^{25}$ The examination of official discourse directed towards children in the context of Soviet history provides another example of how the notion of age and childhood are culturally constructed categories that emerge in various historical texts across time and space. ${ }^{26}$

The notion of rescuing children was not solely a Soviet phenomenon, but a type of project initiated in Western countries including France Germany, and the United States with the implementation of youth groups and children's camps. ${ }^{27}$ These state-initiated child care projects were faced with instilling nationalist and cultural values for young children, especially those from working-class backgrounds.

Soviet schools and children's colonies also underwent similar challenges in their attempts to implement state policies. Whereas during the formative years of the

Literature and Culture, edited by Marina Balina and Larissa Rudova, 3-18. (New York: Routledge, 2008). Jacqueline Marie Olich, Competing Ideologies and Children's Books: The Making of a Soviet Children's Literature, 1918-1935 (Saarbrucken: Verlag, 2009).

${ }^{25}$ Philippe Ariès, Centuries of Childhood: A Social History of Family Life trans. Robert Baldick (New York: Random House, 1962).

${ }^{26}$ David Hamlin, "The Structures of Toy Consumption: Bourgeois Domesticity and Demand for Toys in Nineteenth -Century Germany," Journal of Social History 36 (2003): 857-69.

${ }^{27}$ Laura Lee Downs, Childhood in the Promised Land: Working-Class Movements and the Colonies de Vacances in France, 1880-1960 (Durham: Duke University Press, 2002). In Childhood in the Promised Land, Laura Lee Downs examines the origins and the organization of children's leisure colonies (colonies des vacances) in France during the nineteenth through twentieth centuries. Downs explains how at first, these colonies began as philanthropic ventures that cared for children, but over time were appropriated by municipal authorities to promote hygiene and political agendas. 
Revolution Bolsheviks believed in experimental childhoods as well as egalitarian relations between adults and children, officials in the Stalinist period, dubbed the Great Retreat (from radical ideology) called for the child to be obedient. Until recently Russian-Soviet scholarship on children and childhood was dominated by studies on education and children's literature. Studies on education during the Cold War era characteristically portray Soviet education as totalitarian in nature; banned humanities in favor of technological and practical education. ${ }^{28}$ With the opening of state archives, postSoviet scholars revised the totalitarian perspective on educational establishments, including primary and secondary schools by focusing more on educators' struggles and resistance in teaching state-produced curricula. ${ }^{29}$

It is not until the turn of the century (2000), that historians began to focus more on Soviet childhood in terms of literature, politics, and indirectly empire. ${ }^{30}$ Today, Russian scholarship is undergoing a significant rise on interdisciplinary studies on childhood. Post-Soviet scholarship on childhood tend to be mostly current cultural,

\footnotetext{
${ }^{28}$ H.G. Friese, "Student Life in a Soviet University" in Soviet Education, ed. George Kline, (New York: Columbia University Press, 1957, 57-78.; Jon Lauglo, "Soviet Education Policy, 1917-1935: From Ideology to Bureaucratic Control" Oxford Review of Education 14 (1988), 285-99. Larry E. Holmes, The Kremlin and the Schoolhouse; Reforming Education in Soviet Russia, 1917-1931 (Bloomington: Indiana University Press, 1991). Thomas Ewing, "Ethnicity at School: Educating the 'Non-Russian' Children of the Soviet Union, 1928-1939” History of Education (UK) 35 ( 2006): 499-519.

${ }^{29}$ Thomas Ewing, "Restoring Teachers to Their Rights: Soviet Education and the 1936 Denunciation of Pedagogy," History of Education Quarterly 41 (2001), 471-93. Larry E. Holmes, The Kremlin and the Schoolhouse; Reforming Education in Soviet Russia, 1917-1931 (Bloomington: Indiana University Press, 1991). Thomas Ewing, "Ethnicity at School: Educating the 'Non-Russian' Children of the Soviet Union, 1928-1939" History of Education (UK) 35 ( 2006): 499-519.

${ }^{30}$ Catriona Kelly, Children's World: Growing Up in Russia, 1890-1991 (New Haven: Yale University Press, 2007).
} 
sociological, anthropological or psychological in focus rather than historical. ${ }^{31}$ There are, however, a few notable works on Soviet childhood that look at the creation of a Soviet childhood in the context of the New Soviet Person. ${ }^{32}$ As seen in English scholarship on Soviet childhood, post- Soviet Russian scholarship overwhelmingly concentrate on children's literature whether current or historical context. ${ }^{33}$ One such notable work that looks at the role of early Soviet children's literature in constructing the New Soviet Child is Evgeny Steiner's Stories for Little Comrades. ${ }^{34}$ According to Steiner, the images and messages in children's literature reinforced state ideology and ideas of the new society, and building socialism and taught children how to adapt to these new conditions. In English scholarship, however, it is Catriona Kelly's monumental monograph, Children 's World, which is the first in-depth study of the ways in which childhood was created and transformed over the course of the Soviet period by concentrating on the capital cities.

In order to look at these questions of building a common identity among children both ethnically Russian and non-Russian populations, this project continues the trend of colonial history in Soviet studies by examining the korenizatsiia (nativization) campaign in the day-to-day interactions between indigenous populations and the organs of imperial

\footnotetext{
${ }^{31}$ A.K. Baiburin, Obriadove formy polovoi identifikatsii detei: Etnicheskie stereotypy muzhskogo $i$ zhenskogo povedeniia, ed. A.K. Baiburin, and I.S. Kon (St. Petersburg, 1991). T.D. Butueva, "Fenomen detsvo v traditsionnoy kul'ture mongol'skikh narodov" (PhD diss., Chita State University, 2004).

${ }^{32}$ E.M. Balashov, "Kontury budushchego grazhdanina: Novye i traditsionnye element $\mathrm{v}$ iavleniiakh detskogo soznaniia, 1917-1920-e gody," Nestor 1 (2001): 150-193. E.M. Balashov, Shkola v rossiiskom obshchestve 1917-1927, Stanovlenie Novogo cheloveka (St. Petersburg: Dmitrii Bulanin, 2006). V.T. Kudriavtsev, Smysl cheloveskogo detsva i psikhicheskoe razvitie rebenka (Moscow: URAO, 1997). S.V. Sokolov, "Schastlivoe detsvo" in Sotsial'naia istoriia (Ezhegodink: ROSSPEN, 1997), 159-202.

${ }^{33}$ E.V. Kuleshov, I.A. Antopova eds., Detskii sbornik: stat'i po detskoi literature i antropologii detsva (Moscow, 2003). ; S.M. Loiter, "Detskii fol'klor v istorii russkoi kul'tury" (paper presented at the Obrazy Rossii v nauchnom, khudozhestvennom i politicheskom diskursakh- nauchnoi konf. Conference, Petrozvodsk, Russia, September 4-7, 1995).

${ }^{34}$ Steiner, Stories for Little Comrades, 1999.
} 
powers (be it colonial officials, teachers, local party members or representatives Sovietlead institutions such as Narkompros (the Commissariat of Enlightenment), the ONO (People's Department of Education in both Moscow and Kalmykia) invested so many resources and spent so much effort on literature and education for children not only in the metropole, but in its peripheries. Therefore, my dissertation brings together three bodies of scholarship — empire, the everyday, and childhood — which have yet to be examined together for the revolutionary period. Discourse analysis allows for an understanding of how the Soviet educational and child welfare agencies conceptualized, strategized, and debated these cultural weapons of ideological colonization — through everyday practices of space, the body, eating, and language. In practice, these discourses were themselves contradictory, problematic, or void of historical realities. My dissertation also explores how the Soviet imperial debates and strategies changed over time, as colonial officials' ideologies were confronted with local-ground realities, when state officials and teachers attempted to intervene in children's everyday lives.

By comparing Moscow with a peripheral case study, Empire's Children shows how Soviet children's institutions relied on a variety of media to create an "imagined community" or empire of children. ${ }^{35}$ These same institutions, through propaganda, tried to instill the belief in a common set of experiences in the everyday lives of all children across the empire, regardless of their ethnic background and vast differences that marked their everyday routines. Employing this version of Benedict Anderson's 'simultaneous happening,' in which a common nation is constructed through shared experiences and proliferation of a common press, provides a way to understand how through literature

${ }^{35}$ Benedict Anderson, Imagined Communities: Reflections on the Origins and Spread of Nationalism (London: Verso, 2006). 
and education, as well as the building of children's spaces and material goods, official ideology proclaimed to children how only in a communist society they can be rescued from the backwardness of the Tsarist government and the superstitions from religion, attend school, enjoy work, and love their country.

Beyond creating the illusion of a common Soviet childhood, Soviet pedagogues, literary authors, school directors, inspectors (and other historical agents), devised a binary model -the vnutrennie (the internal) and vneshnee (external)-- of that is found common in various sources, documents and treatises when relating to child care in its various formats (feeding, sheltering, clothing, educating). These two concepts of internal and external elements carried both literal and abstract connotations in that they could refer to the material — actual spaces - internal (i.e., school buildings, homes), as opposed to external (i.e., summer camps, excursions). In regards to the child's body, for example, children's clothing could represent the literal external while eating represented the internal practice of soviet socialization. Yet, these concepts were not strictly limited to biological transformations, but would change the child's mentality and habits from within or internally. Thus, the external/internal dichotomy - loaded in childhood discourse in the sources became a substantial foundation on which to build a common Soviet identity for children, which is explored further within each chapter.

\section{MODERNITY AND MODERNIZATION}

For decades Soviet scholars regarded Russia and the Soviet Union as characteristically backwards, lagging behind the West, especially in its economic and political arenas. ${ }^{36}$ My project positions itself within recent scholarly trends that revise

\footnotetext{
${ }^{36}$ Pipes, Russia Under the Old Regime, 1974.
} 
Russia and the Soviet Union within the framework of modernity. ${ }^{37}$ While the use of modernity as a category of analysis is problematic in its reinforcement of the binary model of Modern v. non-Modern countries that tend to place Soviet Union as 'behind' the West, historical developments and Soviet leaders themselves have understood the Soviet period as modern. ${ }^{38}$

Indeed, the Soviet Union underwent significant measurable and concrete modernization factors that reinforced the Bolsheviks' claims to modernity. These were sentiments which also emerged in the case of children's institutions. ${ }^{39}$ Furthermore, the Bolsheviks revolutionized the political, economic (with Lenin's New Economic Policy in the 1920s, and Stalin's First Five Year Plan in the late 1920s and early 1930s), and technological spheres. Alongside these political, economic and technological developments, the Bolsheviks combined these projects to transform and fit the needs of children entering this new era of what was believed to be Soviet modernity. New children's institutions were erected while pedagogical institutes revamped their education

\footnotetext{
${ }^{37}$ Russian Modernity: Politics, Knowledge, Practices, eds. David L. Hoffman and Yanni Kotsonis (New York: St. Martin's Press, 2000). Laura Engelstein, The Keys to Happiness: Sex and the Search for Modernity in Fin de Siècle Russia (Ithaca: Cornell University Press, 1992).

38 "Introduction: AHA Roundtable: Historians and the Question of 'Modernity'," American Historical Review 116, no. 3 (2011): 631. For more on the debate on the use of modernity as a category of historical analysis, please see more from the AHA forum: Zvi Ben-Dor Benite, "Modernity: The Sphinx and the Historian", 638-652; Gurminder K. Bhambra, "Historical Sociology, Modernity, and Postcolonial Critique" 653-662; Dipesh Chakrabarty "The Muddle of Modernity" 663-675. While this study follows the Russian historiographical and Eurocentric approach, I am aware of the debates and arguments against this method. According to Benite, the problem with 'modernity' is that it is Janus-faced because it reinforces the binary model of those who are modern (Europe" while the rest of the world is regressive or stagnant. Other historians, including Benite have proposed a global modernity method, that is more inclusive and acknowledges that the modernity process was not so isolated in time in space. However, Chakrabarty cautions scholars that this democratization of history is more of a reflection of current historians ' way of thinking than the actual past. The sources in this dissertation support that Russia gazed to the West and employed very similar tactics and saw itself indeed a part of the larger pan-European trajectory of modernity and modernization.

${ }^{39}$ David L. Hoffman and Yanni Kotsonis, "Introduction: A Modern Paradox" in Russian Modernity, 2-3.
} 
to follow scientific and rational criteria that followed Marxist-Leninist ideology. Social scientists, historians, and Bolsheviks themselves self-consciously identified the Revolutionary period as a modern era. Justifying their argument with the physical elements of modernization, it was the discursive or the attitude of modernity that defined the Soviet Union's historical place in the modern world. As Foucault defines in his study, modernity is characterized as the "consciousness of the discontinuity of time." ${ }^{40}$ The Bolsheviks' entire framework for their political drives in official culture was based on this notion of the rupture between the archaic, elitist, old regime, towards the new, egalitarian system. Indeed, the Bolsheviks 'heroized' the present, moment claiming triumph over the 'backwards' forces while rescuing the population from backwardness and repression. ${ }^{41}$ Soviet representatives, including inspectors and pedagogues, were preoccupied with the changing of time in their efforts to implement state-based policies in children's schools and other venues and the establishment of the welfare system, yet another modernization factor. Just as the First-Five Year Plan was seen as a modernizing drive for the economy and industry that required workers reach an unrealistically high output of technological (or in the case of collectivization, agricultural) products, school inspectors met with pressure from above to ensure their students produce an enormous amount of work while "earning" otlichni (outstanding) academic status.

The notion of the individual, a factor in the discourse of modernity, is complex in the Soviet context, since its parameters did not neatly fit in with the Western

\footnotetext{
${ }^{40}$ Michel Foucault, "What is Enlightenment?" in The Foucault Reader, ed. Paul Rabinow (New York: Pantheon Books, 1984), 2.

${ }^{41}$ Foucault noted another marker of how historical actors conceptualize their era as modern, being able to "grasp the heroic aspect of the present moment," Foucault, "What is Enlightenment?",3.
} 
Enlightenment model. In the Soviet case, Bolsheviks often referred to a 'self' rather than the term individual. ${ }^{42}$ The self would refashion into the New Soviet Person, Child, or the Soviet Self through the everyday lives and experiences in dress and routines in eating and hygienic habits. The individual's actions were always to be imagined within the context of the collective whole or the future of communism. As early as the 1920s, the "individual" as conceptualized as a "cog in the machine," thus reinforced the notion of the modernization of the Soviet Union with discourses of collective action and technology. ${ }^{43}$ Over time, and especially under Stalin, the 'self' or selfhood in the Soviet Union became more personal as individuals began to consciously write journals and diaries. Yet, the author would not write about her or his uniqueness or individuality but rather express how their lives were part of a larger scripted movement of the Soviet experience. My study shows how through the production of official culture, the Bolsheviks attempted (and in certain cases succeeded in) creating their own modern subjects, such as scientists and pedagogues who reinforced state ideologies and implemented policies directed towards children. While the Bolsheviks created these modern subjects -the new Soviet Man, Woman or Child - it also inadvertently created historical actors, in the classroom or the home. My study also shows how even though local officials in Kalmykia tried to modernize their subjects, they were met with challenges by the local populations who did not realize that the educational projects as well as other practices introduced by the Soviets were in their best interests. While this

\footnotetext{
${ }^{42}$ More on the self-hood of the early Soviet period in Choi Chatterjee and Karen Petrone, "Models of Selfhood and Subjectivity" Slavic Review (2008).

${ }^{43}$ Victoria Bonnell, Iconography of Power: Soviet Political Posters Under Lenin and Stalin ( Berkeley: University of California Press, 1999).
} 
may seem at first as the local population's attempt to resist Soviet policy, the fact that they continued to practice their traditional everyday habits actually conforms to the overall Soviet korenisatsiia policy, which allowed for cultural ethnic practices to continue after the Revolution. Thus, my study highlights the contradictions and the discrepancies between the official rhetoric of the nationalities policy and the Sovietization projects on the local population.

\section{THE STEPPES: CULTURAL AND HISTORICAL BACKGROUND OF KALMYKIA}

Figure 1: Map of Russia. The Republic of Kalmykia is highlighted in red. ${ }^{44}$

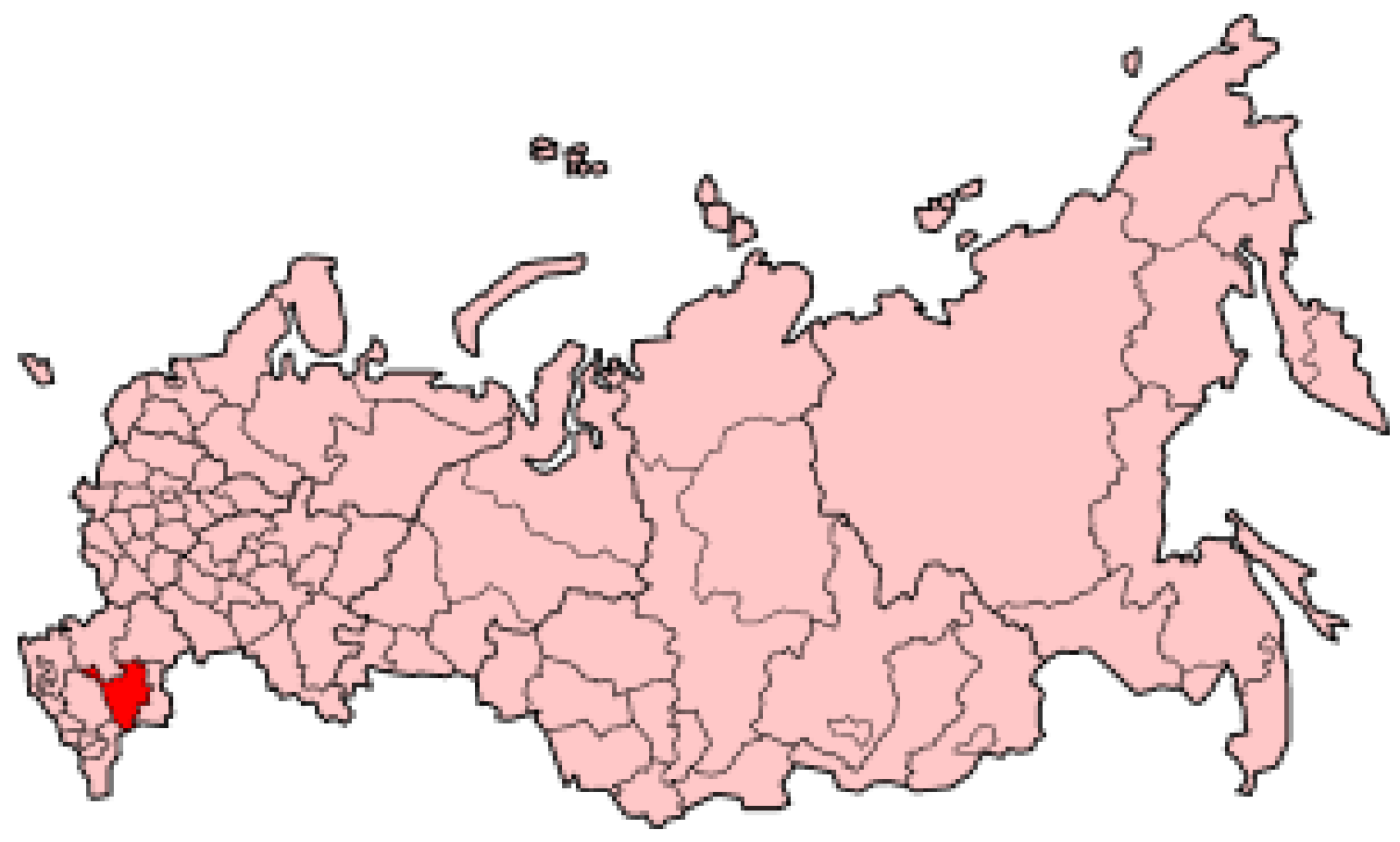

For many centuries, pre-revolutionary Kalmykia was inhabited by a largely nomadic population that practiced the Tibetan-form of Buddhism and acknowledged their

\footnotetext{
44 "Russia Kalmykia," in Wikimedia Commons, upload.wikimedia.org/Wikipedia/commons/a/a3/RussiaKalmykia2005.png, accessed on March 5, 2013.
} 
own ethnic identity as oirat. Even up to the present day Kalmyks remain the only and largest Buddhist population in the West. ${ }^{45}$ Its geographic location, bordering Dagestan to the North and the Caspian Sea where the Volga river flows, to the West, is characterized by its desert-like steppe landscape - generally hot and dry in the summer and cold in the winter, which contrasts differently from Moscow and European Russia's geography and climate of harsh winters and mild summers.

Between the years 1905-07, after the Bloody Sunday Revolution and the defeat from the Russo-Japanese War, Tsarist officials encroached on Kalmyk culture by increasing the Russification of language, religion, and education. ${ }^{46}$ Kalmyk leaders resisted Orthodox religious schools opened by missionaries by establishing some of their own. However, the introduction of Kalmyk education was a result of Russian Imperialism. By the mid-nineteenth century, Kalmyk children's education—relegated to boys - had already been established for centuries and largely followed Buddhist religious instruction. ${ }^{47}$ Unlike other parts of the Soviet Union, Kalmyks had already established their own alphabet and even had their own form of literature. Yet, traditional Kalmyk education was limited to the small educated portion of society who had dedicated their lives to religious service. According to an early Soviet Kalmyk émigré's understanding of pre-Revolutionary Kalmyk culture, if a boy did not enter the religious service, when he turned 15, a father would begin to look for a wife for him so that by 17 he could marry, which was the legal marriage age. When a couple had a child, its birthday would not be

${ }^{45}$ Erdinev and Maksimov Kalmyki, 3; Nationsal'naia Muzei Respublika Kalmykia (hereafter NMRK), N 2174/ 48 "Otchet po Otdelu Narodnogo Obrazovania Kalmitskoi Oblasti”, 87.

${ }^{46}$ Erdiniev and Maksimov, Kalmyki, 375.

${ }^{47}$ Sartikova, Obrazovanie Kalmykii, 43. 
celebrated until the child became 2 years of age, and it was then that they would receive gifts that lasted throughout his or her life. ${ }^{48}$

One example of pre-Soviet Kalmyk children's schooling included learning the alphabet, writing, and religious studies in the first 5 years of school. Those who continued in higher schooling had to complete another 8 years of instruction. Pupils in the first stage of schooling had to memorize 40 religious laws and study the history of the Buddhist religion. According to a Buddhist ex-patriot, in pre-Revolutionary Russia it was "necessary to give [the] wisest and most capable man to the church at the age of 5 or 6 to become a monk." 49 Despite the larger concentration of boys in pre-Soviet schooling, girls were also allowed to attend special schools dedicated to studying both Russian and Kalmyk language as early as 1868 , in accordance with Tsarist law. ${ }^{50}$

The Kalmyks' traditional way of education, life, and everyday habits would change with the October Revolution of 1917 that caused the downfall of the old regime. The Bolshevik takeover immediately following the revolution aimed at establishing a socialist society throughout the vast empire of different ethnic groups and peoples. As early as 1920, Lenin, in his promise of national self-determination to the Soviet peoples, awarded Kalmykia its full-fledged autonomous republic status. ${ }^{51}$ As a result of its status change, Kalmykia, recognized as having its own national identity, had special attention

\footnotetext{
${ }^{48}$ Harvard Project on the Soviet Social System, Russian Research Center Library and Widener Library, Harvard University. (hereafter Harvard Project)The project is available online at http://hcl.harvard.edu/collections/hpsss/index.html (last consulted November 21, 2012). Schedule B-5, Case 23, p. 16.

${ }^{49}$ Harvard Project, Schedule B-5, Case 15, p. 19.

${ }^{50}$ NMRK, "Zhenskoe Kalmytskoe uchilie."

${ }^{51}$ U. E, Erdinev, Kalmyki, 7.
} 
when visited by State officials. While serving in Kalmykia, inspectors and local officials were sensitive to local traditions, including the maintenance of Kalmyk dishes in canteens and the teaching of Kalmyk language in the classrooms. Paradoxically, when Kalmykia earned its status as a full-fledged republic, it tended to suffer more in the retention of its traditional-ethnic identity, especially with the encroachment of StalinistRussification policies of children's education and eating habits.

\section{NARKOMPROS, MOSKOVSKII OTDEL' NORODNOGO OBRAZOVANIIA (M ONO), KALMYTSKII OTDEL’ NORODNOGO OBRAZOVANIIA (K ONO)}

As mentioned above, from its inception, the Soviet state created children's programs, institutions that would facilitate the education of Soviet values and upbringing, Along with the establishment of Narkompros (Commissariat of Enlightenment), the State employed experienced pedagogues to ensure proper and quality education for children. The first appointed head of Narkompros was Anatoly Vassilevich Lunacharsky. Although Narkompros aimed at establishing a central, ordered system, according to Sheila Fitzpatrick the initial stages of Narkompros was "incoherent, rambling, malfunctioning, overstaffed with middle-aged intellectuals and understaffed with proletarian Communists. ${ }^{52}$ Nevertheless, Narkompros took charge of the State Education Commission and advocated free, general education for all, despite class background. Soviet education was initially based on non-hierarchal relationships between teachers and

\footnotetext{
${ }^{52}$ Sheila Fitzpatrick, The Commissariat of Enlightenment: Soviet Organization of Education and the Arts Under Lunacharsky, October 1917-1921 (Cambridge: Cambridge University Press, 1970), xi.
} 
students, with a Marxist-based organization of lessons, particularly those surrounding collectivity. $^{53}$

While indeed the bulk of the Soviet Union's children's institutional instruction came from the State and general programs created by Narkompros-hired pedagogues, state officials were sensitive to local distinctions and needs. Just as the Soviet Union strove in modernizing the population through economic and technological advancements, including programs such as the First-Five Year Plan, so did local pedagogues strive to modernize local educational systems and children's lives. In the case of Kalmykia, perhaps the most influential individual to aid in the modernization and Sovietization of the Kalmyk children's education and homes system was the Ukrainian-born inspector Vasilii Petrovich Porokh. Porokh began serving the Astrakhan region in 1920 just out of the 'wake' of the Civil War that the war had disastrous effects for an already tiny ethnic group, including the 25 percent population loss that resulted from the "liquidation of the Whites and deserters" in the region. ${ }^{54}$ According to Porokh, the connection between Narkompros and the Kalmyk Department of People's Education (KONO) was weak. He attributed the "weakness" to the long, extended, and difficult trips officials had to make

\footnotetext{
${ }^{53}$ Fitzpatrick, The Commissariat of Enlightenment, 32. Elena Shulgina, "Nasledie E.I. Tikheevoi kak tselostnaia pedagogicheskaia sistema" (PhD diss., Moskovskyi Gumanitarnyi Universitet, 2007). Tikeeva was one of the most well-known pedagogues, who was highly regarded in her field and among Soviet child specialists. She served as the head of Society for Promoting the Pre-Schools and Kindergartens between 1913-1928. By 1920, she became Professor at the Petrograd Pedagogical Institute of preschool education and authored several influential pedagogical tracts and manuals including Sovremennyi Detski Sad (The Modern Kindergarten), basing the foundation of her theories and research from Maria Montessori's sensory training.

${ }^{54}$ Viktor Khalkhinov, "Intelligent -Podvizhnik," Elistinskaia Panorama Elista, June 30, 2010, p 3; NMRK, "Doklad initsiativnoy kommunisticheskoy gruppy rabotnikov prosveshcheniia Avtonomnoy Kal'mytskoy Oblasti”, 25 August 1920.
} 
between Moscow and Kalmykia, which made communication nearly impossible and resulted in lack of funds or resources for needy children in the region. ${ }^{55}$

Porokh found himself in a dire situation with mass population loss, a severely wounded population, rampant theft, and the destruction left from the war. ${ }^{56}$ When faced with the ruins of Kalmykia, Porokh took the challenge to build upon the State's emerging educational system. Upon his arrival, Porokh declared that above all else, that Kalmykia's most needed resources were schools and scientifically-trained teachers (again fitting with the modernist notion of the rise of professionals). Porokh declared that "socialist upbringing and political education for children up to 14 years of age [with] schools, children's home's, school colonies would be the most important and most valued of K ONO's work." ${ }^{57}$ His priorities consisted of two duties: First, to build primary schools and also include them outside the capital and around the more rural areas. Second, he wanted to establish technical schools with a short course in agricultural techniques for the rural society, in order to promote self-sustenance and self-reliance. Seeing how the Kalmyks generally continued to live a semi-nomadic life, he decided it was necessary to change their way of life or byt to identify more with a modernizing society. One of his solutions to this was to build boarding schools, in order to house the majority of the orphans that were left behind from the Civil War and protect them from the rampant banditry. For Porokh, establishing the boarding school was an expensive

\footnotetext{
${ }^{55}$ NMRK, N 2174/14 21, p. 16., “ Otchet po Otdelu Narodnogo Obrazovaniia Kalmytskoi Oblasti”,16.

${ }^{56}$ NMRK, "V Glavosotsvos:Otchetnoe Pismo" 1922 and NMRK N 2174/14 21. Porokh complained of extreme situations including, banditry and the decline of workers in children institutions as contributing factors to the overall crisis in the area and education in particular.

${ }^{57}$ NMRK, N 2174/48 “Nuzhni Zaprosi Narodnogo Obrazovaniia Kalmytskogo Oblasti, 1922-23”, 35.
} 
feat, but he was not alone in his efforts. For his projects, Moscow and even some local leaders from Kalmyk society provided Porokh with various necessities, including wooden homes that housed schools, and medicine to help improve children's health. In 1922 he managed to build 33 new school building demanding that schools run through the Fall and Spring.

Despite his appeal for help and resources for children, Porokh continued to struggle with the challenges he faced in post-war Kalmykia. In his letter to the department of education, he lamented that the children went around 'barefoot and naked, having nothing to eat and drink. ${ }^{, 58}$ In addition to the shortage of material and economic provisions, Porokh had trouble holding on to caregivers and teachers, as a consequence of the lack of manpower and even in ability provide decent pay. In fact, Kalmykia had some of the lowest wages in the Astrakhan region, where teachers in Kalmykia earned a meager 27 rubles as opposed to 63 rubles that the average teacher made in Moscow. His personal files reveal that the budget for education was a "catastrophe" and resulted in the "dying out" of the "network of Cultural Enlightenment" in the Kalmyk Oblast. ${ }^{59}$ Understanding the cultural circumstances of Kalmyk peoples, Porokh stated that the dilemma that local officials had at the time was to "strengthen [Kalmyk's] relation to cultural (Soviet) life or continue their semi-wild lifestyle," which would make their progress towards Soviet modernity come slowly. ${ }^{60}$ Nevertheless, as my dissertation reveals, Porokh's struggle and drive to follow State regulations and modernize Kalmykia

\footnotetext{
${ }^{58}$ NMRK, N 2174/45 “Sotsial'noe vospitanoe."

${ }^{59}$ NMRK N 2174 / 45 "Rezoliutsii Obshchekalytskogo S"ezda" 1923.

${ }^{60}$ NMRK N 2174/ 45 “Doklad,” p. 45.
} 
through education and its young population was effective but like its Moscow counterpart, with mixed results.

\section{OUTLINE OF THE CHAPTERS}

The overall structure of the dissertation proceeds through various aspects of the daily life of the Soviet child in the capital and on the periphery. It begins with the child's encounter with the school environment or recreational camp to explorations of the Soviet child's body, and finally, with the child's mind. The next chapter (2) looks at the role of official culture in designing common Soviet environments for children throughout the empire. The chapter establishes one of the main threads of the overall project, as children's education, care for their bodies and consumption were all influenced in one way or another by their environments. Since the beginning of the early Soviet period, Bolshevik ideologues created 'spaces' that were both imagined and temporal in meaning that would allow for children-whether residing in Elista, Moscow, Tashkent or Leningrad - to move and experience similar events in their daily lives. These Soviet spaces could include holidays which shifted old traditions (of Christmas for example) in exchange for secular, Soviet rituals and practices. Spaces were also intended for children to imagine one common environment or way of life that they shared with other children from different parts of the Soviet Union. Places, which are defined as concrete buildings or institutions, held similar roles in the sense that they were the manifestation of state ideologies, primarily those of collectivity and socialization. By designing these institutions in a particular way such as ensuring that children had their own sized furniture or shared their meals on a common table, children would adapt to the Soviet culture of collectivity. These new places and institutions that were built for children were 
various state-led institutions including, children's homes, Kindergartens, schools, seasonal recreational camps all intended to protect children, provide knowledge and shape their daily lives, both indoors and out. The notion of children's spaces and places, however, shifted and varied not only over time, but even simultaneously. For example, the outdoors had both positive and negative connotations, as on the one hand, children needed to be outdoors to strengthen their health, but on the other, children who lived on the streets were seen to be in danger and a danger to society and even a threat to the socialist state. Spaces and places were significant factors in the Soviet modernization process. Bolshevik leaders were conscious of the creation of spaces, using rationality and social sciences (i.e. geography), while actual places were established with other 'modern' tools such as architecture, mathematics and sciences.

Following the ideas of protecting children while modernizing their everyday lives, Chapter 3 traces the various ways in which Bolshevik pediatricians and specialists continued to engage with notions of modernity in devising collective experiences and instilling Soviet citizenship through the child's body. As was true for the New Soviet Man and Woman, the New Soviet Child was outwardly clean, well-dressed and groomed while inwardly pure and self-disciplined. As evident in inspectors' reports and official letters, these ideas and their practices were not only experienced in Moscow but spread through remote areas, including the Republic of Kalmykia and the Astrakhan region. Hygiene and dress became part of an imperial strategy to modernize the population's way of lives, starting with children.

Chapter 4 continues in the same vein of the body only turns the attention from cleanliness, hygiene and outward appearance to food consumption and practices. Just as 
children were to experience education, playtime, and cleaning in the same manner, food became another factor in instilling Soviet values in children throughout the empire. While initially, food practices in the early Soviet period differed according to region and location, increasingly over time, food consumption and eating habits became more russified in both the types of food consumed as well as the utensils and eating arrangements made in the stolovaia (canteen) and at the lunch table.

While the last two chapters (and in a sense the first one) focus on more concrete aspects of the child's body, Chapter 5 returns to the abstract aspect of the child's everyday life and looks at the mind, or more specifically language education and literacy. Just as the other Soviet-led projects (space, the body, and food) were implemented to instill notions of citizenship in children throughout the Soviet Union, so did language acquisition. Language acquisition, like dress and food, was supposed to be more of a localized experience in the sense that, for example, children in Kalmykia, according to the nationalities campaign, were to learn school subjects in their native language, yet over time, Russian dress, food, and language became more synonymous with the rational, modern and thus Soviet.

The concluding chapter briefly highlights the dissertation's main findings, while also projecting the ways in which the early Soviet projects of building a common citizenship among a disparate child population was a lasting legacy even well after Stalin's death. It examines external cases of how the Soviet childhood campaign and intervention of children's everyday lives extended beyond Soviet borders and became a part of non-Soviet child citizens' identity, particularly Spanish child refugees fleeing from the Civil War in Spain in the late 1930s. This chapter reveals how the legacies of 
the Soviet imperial and childhood campaigns transcended through time and national borders. 


\section{CHAPTER II: THE CHILD COMPASS: SPACE AND PLACE IN THE SOVIET IMAGINATION}

The Stalinist-era elementary school textbook Geograficheski Atlas (Geography Atlas) features a young pioneer boy in uniform, standing with his arms extended side to side in the center of a map of the Soviet Union. The caption under the illustration describes the cardinal directions of North, South, East, and West, therefore making the boy the actual compass itself. The use of this pioneer boy is more than just a didactic illustration in cartography, but a symbolic and visual reflection of how the child stood at the center of Soviet imaginings of space, place, and Revolutionary progress. ${ }^{61}$

As early as 1917, the Bolsheviks constructed new places, including school buildings and preschools, that catered to children's biological and social needs. With the onslaught of the Civil War (1918-21), the Bolsheviks established numerous children's homes throughout the Soviet Union in order to accommodate the staggering rise of homeless (besprizornye) children. The Soviet project of creating new norms of childhood, though, involved not only creating new places, like the orphanages, but also reimagining something much more abstract: space. Space encompasses the experiences or interactions within any given place, such as holiday celebrations, political conflicts and other events that influence an individual's perception. ${ }^{62}$ In other words, space is “a

\footnotetext{
${ }^{61}$ Editor V. G. Erdeli , Geograficheskii Atlas dlia 3-ogo I 5ogo klassov nachal'noi shkoly, Razrabotan Tsentralnym Nauchno-Issledovatel'slim Institutom Geodezii, TsMOOGA i K pri uchastii uchitelei moskovski shkol Gosudarstvennoi S'emki I Kartogorafii NKVD SSSR, 13.

${ }^{62}$ Stephen Kern, The Culture of Time and Space, 1880-1918 (Cambridge: Harvard University Press, 1983), 3.
} 
practiced place. ${ }^{93}$ The notion of space is not fixed, but changes in meaning and function over time and even simultaneously. Place, however, encompasses real, concrete structures or environments that range from classrooms to parks to monuments. The construction of common places, (i.e., fixed structures such as children's homes, camps, and kindergartens) allowed for a creation of the common space—abstract, temporal—of a Soviet childhood no matter where in the empire a child resided. Soviet places and spaces for children served a dual purpose. First, Soviet children's spaces and places established a geographical identity or imagined community of children through the everyday occupation of particular places such as the school. Second, these sites of children and spaces were part and parcel to the Soviet modernization process, along with the development of technology and industry. Yet, the loci of Kindergartens, homes, camps, libraries, became more than sites of Soviet education and common childhoods, but also functioned as fortresses that both surveilled and protected children from homelessness, the cold, and 'foreign' elements - all depending on particular historical factors such as the Civil War, NEP period, famines, and purges.

Soviet pedagogical professionals in the Kalmyk Autonomous Oblast (or Republic in the 1930s), Moscow, developed ideal places and spaces for children throughout the Soviet Union. Examining both locations allows us to see past the Bolshevik ideals of constructing or imagining the space of Soviet childhood and provides an understanding of how these places and ideals took shape in reality in various parts of the Soviet Union. While scholars who focus on colonial sites tend to argue the distinctiveness or exclusion from the Soviet modernizing projects such as industrialization or medical care, I argue

${ }^{63}$ Michel de Certeau, The Practice of Everyday Life, trans. Steven F. Rendall (Berkley: University of California Press, 1984), 117. 
that in fact, both Kalmyk and Muscovite children's everyday experiences in Soviet institutions were more similar in nature in terms of their conceptualization, implementation, and consequences, despite the pervasiveness of the imperialistic ‘national self-determination' slogans and campaigns that increased in the 1930s under Stalin. In fact, inspectors' reports, inventories, and interviews that describe Kalmyk children's daily activities reveal how geographical sites resembled more of their urban Russian counterparts'. Propaganda journals, education books, children's literature, and local officials' notes mapped out children's spaces in the same way that Soviet geographers and cartographers drew territorial boundaries in first years of the revolution. School instruction manuals, school officials' notes, school and camp inventories and inspectors' reports reveal the striking similarities of children's institutional spaces in both Kalmykia and Moscow in their conceptions as well as the struggles school instructors and children experienced in them. The places and spaces such as the children's homes and classroom provide a general setting for the subsequent topics in this dissertation that address issues concerning children's welfare under state institutions, and the way in which the environment both imagined in propaganda and constructed in reality, served to transform children's everyday lives in the new socialist state.

Developing the Soviet common space for both Russian and non-Russian children were part of larger imperial processes that took shape during the early Revolutionary period. The conceptualization of the Tsarist and Soviet empires were linked to nineteenth-twentieth century imperial projects of the West, built upon scientific-based research and the emergence of new professions, including ethnography and cartography to imagine borders. The territorial borders in the Russian Empire were never fixed, but 
were in flux and contingent on historical processes. ${ }^{64}$ Thus, imperial space was comprised of 'open-ended' and ill- defined, vague territories rather than a fixed relationship or defined border between the center and periphery.

According to recent scholarship, geographical space is not an objective category, but is rather composed of subjective sites that hold deep political, social, and religious meanings despite their "real" geographical place (i.e., river, mountain) or man-made structure (i.e., battleships, monuments). ${ }^{65}$ Furthermore, these natural and man-made phenomena are what Christopher Ely refers to as 'geographies of identity,' because of their ability to function as sites of memories (historical, political, religious) as well as natural geographic features. Despite these 'geographies of identity,' Soviet leaders were troubled with projecting the Soviet Union's self-image as an empire, not only because of the political, anti-colonial stance they took, but also because of its blurred boundaries and geographical borders. Another way in which the notion of space is a subjective concept that changes in meaning and perception not only over time, but as with the case of children, within the same time frame. One prominent example in the early Soviet period

\footnotetext{
${ }^{64}$ Jane Burbank and Mark von Hagen, "Coming into the Territory: Uncertainty and Empire", in Russian Empire: Space, People, Power, 1700-1939, ed. Jane Burbank, Mark von Hagen, and Anatolyi Remnev (Bloomington: Indiana University Press, 2007), 16.

${ }^{65}$ Mark Bassin, Christopher Ely, and Melissa K. Stockdale, eds. Space, Place, and Power in Modern Russia: Essays in the New Spatial History (DeKalb: Northern Illinois Press, 2010). Although these definitions of Russian space are mostly broad and geographical in their discussion, their focus on Russian space as holding political meanings are drawn from Michel Foucault's interpretation of institutional spaces as 'micro-power relations.' They also add that Foucault's definitions reinforce Said's concept of Orientalism, where the West (Western Europe, U.S.), in a sense, invented the "Orient" in order to redefine its place in the world, as a or the center of civilization and modernity. The authors' conceptions of place and space relate to de Certeau's definition which articulates place as a proper location that is fixed and stable. According to de Certeau, space is a more abstract concept. In his famous study The Practice of Everyday Life, de Certeau argues that while place connotes "proper" and "distinct location" space is "composed of intersections of mobile elements", thus making it specific to time and movement within a particular place. See de Certeau, The Practice of Everyday Life, 117; Michel Foucault, Discipline and Punish: The Birth of the Prison (New York: Random House, 1977). Edward Said, Orientalism (New York: Pantheon Books, 1978).
} 
is the outdoor space (i.e., streets, yards) - which was at once beneficial and detrimental to children. According to Bolshevik child specialists, outdoor space aided in strengthening children's health by exposing them to the sun, or the streets aided in their socialist upbringing when they encountered Soviet architecture and other structures during excursions. Yet, the streets could also be harmful to children, especially those who lived on them who were seen as a social threat and potential hooligans. ${ }^{66}$

Soviet-Bolshevik projects from 1917 onward redefined or rather established a more seemly fixed territorial location. These territorial identifications were possible through the incorporation of advanced scientific research and the hiring of 'socialists and experts,' whose mapping of Russian- Soviet territory affected everyday lives of ordinary residents by including them in territories that did not accurately coincide or represent the correct ethnic group. ${ }^{67}$ The Bolsheviks' incorporation of scientific professionals in their nationalities campaign was implemented not only to promote their ideology of socialism in one country, but was also a move to break from the past. ${ }^{68}$ Working with scientists and experts, the Bolsheviks drew borders aimed at redesigning the Soviet nation as a "modern" and progressive state, with its political, economic and industrial innovations, while distinguishing themselves from the tsarist-exploitative-imperialist predecessor.

\footnotetext{
${ }^{66}$ For more on homeless children, please see Alan Ball, And Now My Soul is Hardened: Abandoned Children in Soviet Russia, 1918-1930 (Berkeley: University of California Press, 1996).

${ }^{67}$ Francine Hirsch, Empire of Nations: Ethnographic Knowledge and the Making of the Soviet Union (Ithaca: Cornell University Press, 2005).

${ }^{68}$ This was an ideology that marked a shift in Bolshevik politics that no longer expected the international communist revolution to take place and focused inwardly in constructing socialism domestically. For more on 'socialism in one country' please see Ronald Grigor Suny, The Soviet Experiment: Russia, the USSR, and the Successor States (Oxford: Oxford University Press, 2011), 168-173.
} 
The creation of children's places and spaces as nationalist (in terms of imagined communities according to Benedict Anderson's theory) and modernizing projects (in terms rescuing and protecting children through the creation of new institutions) were not unique to the Soviet Union, but were part of broader global nation-building trends. For example, during early Turkey's transition into a nation-state in the early twentieth century, the Republican government centralized the education system in order to instill a collective memory in school children. ${ }^{69}$ Through textbooks, geography lessons, and strategic placement of school buildings, children acquired nationalist sensibilities by conceptualizing their spatial environment. In the early 1900s, Western European nations as well as the U.S. constructed summer camps and open-aired schools to both protect and rehabilitate 'sickly,' poor children, which at the same time served to raise nationalist awareness by showing the children how the state cares for them, while teaching them civic and nationalist values. $^{70}$

${ }^{69}$ Zeynep Kezer, "Molding the Republican Generation: The Landscapes of Leaning in Early Republican Turkey" in Designing Modern Childhoods: History, Space and the Material Culture of Children, edited by Marta Gutman and Ning de Conick Smith (New Brunswick: Rutgers University Press, 2008). In the Soviet context, Lisa Kirschenbaum examines how the preschool signified the revolution's 'scientific' vision of modernity and progress, with the 'engineering of childhood,' while at the same time revealing how the special status of children was not a myth but a 'scientific' reality. For more on early Soviet preschools please see: Lisa Kirschenbaum, Small comrades: Revolutionizing in Soviet Russia, 1917-1932 (New York: Routledge, 2001), 2-5.

${ }^{70}$ Also see Abigail Van Slyck, "Connecting with the Landscape", Ariene Cusins-Lewis and Julia Gatley's "The Myers Park Experiment" and Anne-Marie Châtelet, "A Breath of Fresh Air", all in Designing Modern Childhoods: History, Space, and the Material Culture of Children, edited by Marta Gutman and Ning de Conick Smith (New Brunswick: Rutgers University Press, 2008); Laura Lee Downs, Childhood in the Promised Land: Working-Class Movements and the Colonies De Vacances in France 1880-1960 (Durham: Duke University Press, 2002). For studies on $19^{\text {th }}$-century children welfare projects and orphanages see: Lydia Murdoch, Imagined Orphans: Poor Families, Child Welfare, and Contested Citizenship in London (New Brunswick: Rutgers University Press, 2006). For more on children and geography see: Children's Geographies: Playing, Learning, Living, edited by Sarah L. Holloway and Gill Valentine (London and New York: Routledge, 2000) and Childhood in Question: Children, Parents and the State, edited by Anthony Fletcher and Stephen Hussey ( Manchester and New York: Manchester University Press, 1999). For more studies on space in the Soviet context please see: Svetlana Boym, Common Places: Mythologies of Everyday Life in Russia (Cambridge: Harvard University Press, 1994), 21. 
The concepts of children's spaces and places in Soviet official discourse and ideology showcased modernizing factors embedded within these plans including industry, technology, light, and science in the new socialist society. Soviet leaders and pedagogues mapped out children's spaces in the same way that Soviet geographers and cartographers drew territorial boundaries separating ethnic populations during the nationalities campaign. Soviet propaganda addressed a broad audience throughout the empire, ranging in all ages and ethnic backgrounds. Although children's places and spaces, like territorial boundaries, were planned scientifically and rationally to represent the modernization of the State, they were subjective in terms of where in the Soviet Union they were located. Children's spaces and places held political meaning, aimed at building an historical imagination among children. All of these components factored into official discourse of progress, inclusion of national minorities in State projects, and child rescuing, thus making children and childhood as a central component to the construction of Soviet imperial space and imagination, just as the Atlas in the chapter's intro situated children in the center of the Soviet-building project. These discourses of national selfdetermination and childhood spaces allowed for children in non-Russian regions to understand their place within their respective territorial boundaries which was at both

Taking Boym's study as a point of departure, David Crowley and Susan Reid examine the everyday in both national spaces and intimate ones to show how 'socialist spaces' are not fixed, but reveal an interaction between ordinary citizens and their use and understanding of State spatial organizations. For Crowley and Reid 'socialist spaces' ranged from large monumental sites, to communal apartments. Some of their examples of 'socialist spaces' include a steel foundry which could figure as the 'forge of communism' or a house commune as a microcosm of the socialist order and a children's after-school facility as a paradigm communist 'city of the future.' According to Crowley and Reid, even the grand sites such as the Workers' Palace were considered 'everyday space' because "socialist ideology professed these spaces belonged to everyone." Thus, 'socialist spaces' pertain to the structure or organization of State-led projects. These socialist spaces would be noted as strictly Soviet phenomena as the sites were not necessarily fixed but held various communal purposes. See David Crowley and Susan E. Reid, eds. Socialist Spaces of Everyday Life in the Eastern Bloc (New York: Berg Press, 2002), 4, 8. 
culturally distinctive and socially common with Soviet spaces, evoking feelings of belonging. This idea of territorial belonging resonates with the nineteenth -century Eurasian scholarly notion of edinstvo mnozhestva or mnozhestva edinstvo, respectively "unity in diversity" or "diversity in unity."71

These juxtapositions of national unity and cultural distinction among children manifested in the form of appropriate spaces and places built for them, and were often the subject in propaganda serials, children's literature as well as national and local instructions for teachers. Concrete places, (i.e., schools, children's squares, cultural centers, and children's homes), were all components of what made up the ideal space for a Soviet childhood. Even concrete places such as school buildings, were strategically located, and featured other uses or purposes aside from being sites of learning. They became spaces of protection, nurturing, and character-building for children. In fulfillment of the nationalities campaign, pedagogues and child-care professionals were preoccupied with children's byt- their everyday lives -- and aware of how their cultures influenced or would potentially challenge Bolsheviks' attempts at building schools or other non-native children's institutions. $^{72}$

The discursive spaces and the attempts in the strategic placements and purposes of key children's institutions in both Kalmykia and Moscow tried to follow national mandates and discourses. Children's spaces throughout the Soviet Union were created echoing state rhetoric of scientific advancement and modernization by carefully choosing

\footnotetext{
${ }^{71}$ Mark Bassin, "Nationhood, Natural Regions, Mestorazvitie: Environmentalist Discourses in Classical Eurasianism" in Space, Place and Power in Modern Russia: Essays in the New Spatial History (DeKalb: Northern Illinois Press, 2010), 51.

72 The Russian concept of byt is explored in the introduction of the dissertation. According to Svetlana Boym, the term byt takes on a distinctive, cultural characteristic that refers to the mundane routines of everyday life. Please see Svetlana Boym, Common Places.
} 
institutions' locations, measuring interior spaces, and being aware of material culture. However, the state intentions of revolutionizing environments were hindered or slowed by the concrete, historical realities and struggles local officials faced in their attempts to create and maintain these ideal spaces for children. There were both external factors -such as the Civil War and purges-- and internal ones -including, employee neglect and material scarcity-- that impeded in realizing national-imperial childhood projects.

Although children throughout the Soviet Union did not live or reside in the 'ideal' Soviet space made for them, they did share common spaces of learning, socializing and struggling from the hardships resulting from lack of space, overcrowding, and even child homelessness.

\section{IMAGINED BORDERS: COMMON CHILDREN'S SPACES AND PLACES IN}

\section{SOVIET OFFICIAL CULTURE}

In a 1925 instructional letter to teachers from the Kalmyk ONO (People's Department of Education) addressed to teachers in the region, it states the necessity to understand the "region's own byt (way of life, routines), geography, and economic level of life in the Kalmyk steppe., ${ }^{73}$ It advised that doing so would ensure a successful school environment, both culturally and age appropriate "meeting the demands of Soviet contemporary society." 74 Its author, I.S. Konovalov, continued to explain how the state educational program was translated and printed in Kalmyk so "that the themes will be

\footnotetext{
${ }^{73}$ NMRK, N 2174/25 I.S. Konovalov, Instruktivnoe pismo No. 5 k Uchiteliam-Kalmykam i provedenii nationalizatsii shkoli 1-y stupeni v Avtonomnoi Kalmytskoi Oblasti s 1925-1926 ych g. (Astrakhan: Tipografiia Kalm. TsIK, 1925), 17.

${ }^{74}$ NMRK, Konovalov, Instruktivnoe pismo, 17.
} 
well understood."75 Also, while it understood the cultural distinction of Kalmyks, The letter, though written with Kalmyk society and children in mind, shows an attempt to combine the Bolshevik ideas of national unity with Soviet childhood. It also shows the ways in which geography and space became critical to the Soviet childhood experience and the tension of uniting disparate ethnic groups into one common identity at least in the classroom where children in Kalmykia also had to read "January 1905, and 25 February 1917" as well as "Spring Agricultural work, Family and School" and "The First Day of May" all significant dates and places in Soviet iconography. ${ }^{76}$

Spatial concepts in relation to children and state-planning were not limited to Kalmykia nor Moscow, but were discourses prevalent in Soviet propaganda, intended for all Soviet peoples. Combining two historically disenfranchised or oppressed groups-ethnic minorities and children (in the Soviet-Russian context) -- Soviet propaganda and newspapers including, Komsomol 'skaia Pravda, Pravda, and SSSR na Stroike (USSR in Construction), reported over the span of 20 years the ways in which the Bolsheviks rescued the population throughout the Soviet Union from the tsarist, bourgeois government, creating a common past in the imperial imagination. The old space of Russia would be replaced with the new, modern, and liberating Soviet one with the redrawing of territorial boundaries that created a semblance of fixed space allowing for ethnic autonomy in governance. These ideas became even more pervasive in the 1930s after Stalin's First-Five Year Plan (FFYP), when news boasted how the rapid industrializations

\footnotetext{
${ }^{75}$ NMRK, Konovalov, Instruktivnoe Pismo, 7.

${ }^{76}$ NMRK, Konovalov, Instruktivnoe Pismo, 8.
} 
of republics transformed the backwards landscape with new constructions, roads, and railways connecting the Soviet Union.

Bolsheviks claimed victory over these "nameless countries" as well as implementing projects collecting children's folklore and songs from around the Soviet Union. ${ }^{77}$ Creating and preserving national culture and childhood throughout the Soviet Union were ideas disguised as fairytale- like legends. For example, the 1935 issue of USSR in Construction celebrating Kazakhstan's $15^{\text {th }}$ Anniversary as a Soviet republic declared that as a result of Bolshevik power, "water began to flow in this waterless steppe." 78 The article featured a picture of three Kazakh children with a caption reading, "Beloved healthy, happy children have a future before them which we could not see in the blinding light of the First Five-Year Plan." ${ }^{79}$ Similar articles with notions of Soviet progress in peripheral territories were republished and differed only in geography. ${ }^{80} \mathrm{In}$ Kalmykia, for example, the Bolsheviks even claimed that they "saved the Kalmyks from extinction." ${ }^{81}$ Nevertheless, the message was always the same: the Bolsheviks, with their modernization projects, "creating" new countries, spaces and places for children, brought these nations "to the map" which gave the children residing in them a history and a future. Even children's literature books, such as those that Alex Saranin described filled

\footnotetext{
77 "Nameless country" was a reference made to Soviet victory in modernizing Kazakhstan as seen in "The $15^{\text {th }}$ Anniversary of Kazakhstan" in USSR in Construction, no. 11, 1935. "Ekspeditsia Shkolnikov za narodnimi skazkami i pesnami," Komsomol'skaia Pravda, August 9, 1936, p 4.

78 " $15^{\text {th }}$ Anniversary of Kazakhstan", USSR in Construction, 1935.

79 “ $15^{\text {th }}$ Anniversary," USSR in Construction.

${ }^{80}$ See "The $15^{\text {th }}$ Anniversary of Soviet Karelia," in USSR in Construction, Issue no 9, 1935; "Molotov Automobile Works, Gorki" in USSR in Construction, issue no. 11, 1936.

${ }^{81}$ Harvard Project, Schedule B, Case 23, p. 11.
} 
his elementary school's library shelves, promoted ideas of the Soviet Union as the only geographical location in the world where children could obtain a Happy Childhood. In his discussion on library books, Saranin explained how "they were often stories about poor black children in Africa, Australia, and America who were always exploited and severely punished by the rich and powerful whites." ${ }^{\prime 2}$

For the Bolsheviks, imagining a community of children's space in terms of geography was not limited to conceptualizing the Soviet Union as a whole. Soviet pedagogues and architects changed children's everyday lives by changing their local landscapes, and by introducing new, modern buildings and places. One of the most prominent examples of an actual shared place and space for all children of the Soviet Union was the famous Pioneer (communist children's organization) camp, Artek. In addition to uniting children from all over the Soviet Union, in Artek, children shared an outdoor life experience within this planned natural space. Sensitive to geography, space, and culture, the USSR in Construction issue of "Children of the Soviet Union" reported on the camp's 10-year anniversary, describing the "sunny" surroundings of "poplars...cypresses, on the southern coast of the Crimea" where children from all parts of the country come every year, from the "Far East and the Cold North, children of the steppes of the Volga, from Moscow and Leningrad, and from Yakutia and Karelia." 83

The construction of children's spaces, places, and everyday lives did not solely entail sweeping landscape changes or grand technological advancements. The Soviet Union separated itself from capitalist nations boasting its special dedication of buildings

\footnotetext{
${ }^{82}$ Alex Saranin, Child of the Kulaks (Queensland: Queensland University Press, 1997), 30.

83 "Children of the Soviet Union", in USSR in Construction, Issue no 6, 1935.
} 
and institutions for children such as children's tourist and excursion stations, children's "townlets" and cultural centers. ${ }^{84}$

Yet as early as 1920, Soviet pedagogues paid attention to even more micro spaces and places of children's environments within educational institutions, primarily focusing on the classroom. In fulfillment of one of Lenin's drive to modernize the Soviet landscape through electricity with the establishment of Goelro in November 1920, the ideal Russian classroom was to be equipped with "electric lighting", brightening the room with lamps. ${ }^{85}$ Light was a crucial component to any child's place regardless of age group or activity it was built for. In an instruction manual published in 1919, the authors advised that "lighting was one of the most important features in the Kindergarten." Schools in both Kalmykia and Moscow invested time and rubles in planning and ensuring that children's institutions were well-lit. ${ }^{87}$ The proclamations of light relating to modernity, enlightenment, and progress continued well into the 1930s in both locations. In Kalmykia, school officials spent a lot of effort in requesting and ordering kerosene

\footnotetext{
84 "Children of the Soviet Union", USSR in Construction, 1935. Among these, the article refers to other places dedicated to children such as children's sectors in workers' clubs, and over 107 houses of art education for children to learn music, acting, sculpting and other forms of fine arts.

${ }^{85}$ Ronald Grigor Suny, The Soviet Experiment, 155. Tsentral'nii Arkhiv Moskovskii Oblasti, (hereafter TsAMO), f. 6764, o. 1, d. 3, p. 27.

${ }^{86}$ Elizaveta Tikheeva, M. Ya. Morozova, I Chulitskaia Tikheeva, Sovremennyi Detskii Sad: ego znachenie i oborudovanie (Peterburg: Gosudartvennoe Izdatel'stvo, 1920).

${ }^{87}$ Natsional'noi Arkhiv Respubliki Kalmykia (hereafter NARK), "Spiski zatrudnivkov narodnoe obrazovanoe skhol, kolonii, detdomov," 1921-32, 240-242.
} 
lamps while in Moscow, local officials complained that children's homes lacked light and "resembled the worst restaurants."

In addition to lighting, the ideal classroom or learning place in the Soviet Union had to include age-appropriate furniture such as desks and benches. State pedagogues suggested child-sized beds in orphanages and boarding schools. ${ }^{89}$ Soviet pedagogues and local school inspectors placed emphasis on familiarity of space for children, away from 'alien’ elements which they argued were harmful to child developments: “... a Kindergarten should be a place where children live their natural childhood (estestvennoi detskoi zhizn'iu). ${ }^{90}$

For the Bolsheviks, 'alien' places were more than just uncomfortable conditions (such as oversized furniture or undecorated rooms) for children. 'Alien places' comprised of the 'unknown' unfamiliar space that was neither modern nor Western, nor in this case even Russian. Thus, Soviet children's places for children were rationally planned and well-organized vis à vis furniture and room décor would occupy the rooms. One of the most prominent examples that made the Soviet experience of childhood more uniform was the place of the classroom. The classroom was imagined - in several propaganda articles, contemporary photos from local officials, and children's books - as the pinnacle of the 'modern' school equipped with chalkboards, desks, globes, and maps, an increasingly central feature of pedagogy in the schools. Even in Kalmykia the map was

\footnotetext{
${ }^{88}$ Tsentral'nii Arkhiv Goroda Moskvi (hereafter TsAGM), f. 528, o. 1 d. 416, "Stenogramma Konferentsii rabotnikov detskikh domov, o poriadkah, trudovyi obuchenie i gramotnosti-vospitanikov detskhikh domakh ot 4 aprelia 1936."

${ }^{89}$ TsAMO, f. 6764 o. 1 d. 3, "Primernaia grupikova odnorodnikh predmetov, inventarnogo kharaktera," 1922, p. 27. Tikheeva, Sovremennyi, 65.

${ }^{90}$ Tikheeva, Sovremennyi, 13.
} 
one of the most essential accessories to any classroom, as evident when an inspector noticed that a missing map in a classroom was a cause for the failure of students' performance at a Kazakh minority school in the Astrakhan region. ${ }^{91}$ In essence, because of their functionality of educating and homogenizing experiences for children, classrooms served as microcosms of the socialist-imperial projects. Furthermore, classrooms and halls were key communal spaces and places for socializing children, promoting equality and Soviet work ethic. ${ }^{92}$

Soviet discourses on children's spaces emphasized collectivity in work, learning, and shared experiences of going to camps and schools. All children in the Soviet Union, regardless of their nationality were to have access to these places and spaces. In Kalmykia, this meant the dramatic shift from home schooling in yurts (round tents) sitting on the ground or, in the case of Kalmyk children who attended spiritual schools in temples, or those who attended administrative schools that prepared children for work in Russian bureaucracy, shift to concrete walls adorned with portraits of Lenin and Stalin, equipped with sleek wooden desks and chalkboards. ${ }^{93}$ The 'modern' or Western-style notions of places as spacious, rationalized, and well-planned into camps, classrooms, with carefully selected furniture for children, trumped ethnic- traditional ones, that should have been promoted as a reflection of the nationalities campaign.

\footnotetext{
${ }^{91}$ NARK "Svedenie Griveosskogo" U ONO Kalmyk ASSR, f. R- 92, o. 2, d. 10, p. 8.

${ }^{92}$ TsAGM, f. R-528 o. 1 d. 535 "Zapisi igr detei za 1937 god".

${ }^{93}$ NMRK, "Delo Prosvetleniia v Avtonomo Kalmytskoi Oblast: Neskol'ko slov o Proshlom January 21, 1921" 1-6. Also see NMRK N. 813 - photos of pre-Revolutionary Kalmyk classrooms and school houses. The "Delo" describes three types of schooling in $19^{\text {th }}$-century Kalmykia, which includes spiritual (located in temples), administrative (in modern classrooms), and local, which took place at home and was most common. In administrative-Russian schools, the classrooms resembled more of those in Western Europe, with hard wood desks and science posters featuring illustrations of animal species and human anatomy as well as photos of local sites in Kalmykia.
} 


\section{STRATEGIES OF SOVIET CHILDHOOD SPACES: INDOOR SPACE, OUTDOOR}

\section{SPACE AND NO SPACE}

Just as "collectivity," "modernity," and "rationality" were building blocks for normative Soviet childhood in official discourse, local officials in both Kalmykia and Moscow adopted these concepts when planning, discussing, and changing children's everyday spaces in their respective locales. Holidays also played a role in strategizing and manipulating children's spaces by transforming the places' original daily function whether learning, playing or resting, to spaces of celebrations and political awareness. In short, strategic spaces were state-planned places. In other words, strategic spaces could be institutions such as schools or orphanages that were manipulated by local officials to restructure children's everyday lives, follow Soviet notions of progress and modernization and further reinforce the nation's break from the tsarist past. In Kalmykia and Moscow, local officials designed particular places -whether indoors or out - to serve official discursive goals. These spaces which took place in children's homes, schools, Kindergartens, children's squares, and camps went beyond their 'official roles' as just places of education and socialization, but would also be protectors of children's bodies and minds from external influences whether ideological or environmental.

One of the earliest examples from Kalmykia comes from a 1921 inspector's file where officials requested aid for children's organizations and institutions to "help those in the injured regions." 94 On the surface, the sole function of the building of children's places and institutions was to offer protection and provide necessities for child care. Yet, before meeting those goals of child protection, the Bolsheviks invested resources in the

${ }^{94}$ NARK, f. $R-25$ o. 1 d. 116 "Doklady inspektorov", p. 8. 
design, planning, and strategic placement of any particular children's institution. According to the inventory of schools in the Kalmyk Bazaar, School No. 1 was divided into two equal segments: the classroom and teacher's room. The classroom, (as well as other rooms in the building), was drafted with distinctive measurements made as standards. ${ }^{95}$ Yet, the engineering of these "modern" places was not the only way Soviet officials in Kalmykia rationally planned out children's spaces. Soviet engineers also devised where in the region, city, or neighborhood these buildings should be placed. Over time, especially in the 1930s, the Kalmyk landscape changed even more from its vast steppe land, marked with yurts (round tents) and old tsarist-era school houses, to more Sovietized ones, including more children's cultural centers such as theatres and clubs. ${ }^{96}$

The careful and rational planning of children's institutions was not unique to Kalmykia. Similar transformations took place in Moscow district (oblast) and Moscow city (gorod) children's places. For example, the children's home Lenin, was situated 3 $\mathrm{km}$ from the city, near a railway station and business as well as an electric station. ${ }^{97}$ The Bolsheviks justified the children's home location by explaining how its close proximity would allow the workers to easily service the home, and facilitate children's lives and needs. In fact, children interacted with these workers, since part of the home separated for them. The home housed 500 children of school age in one section, and 140 workers in another. Furthermore, Lenin's Home No. 1 went beyond just a space for child protection.

\footnotetext{
${ }^{95}$ NARK, f. R-25, o. 1 d. 116 , p. 150.

${ }^{96}$ NARK, f. R-92, o. 2 d. 10 "Svedenie Privolzheskogo - o likvidartsii negramotnostii. Also Komsomol'skaia Pravda, August 9, 1936.

${ }^{97}$ TsAMO, f. 2614 o. 1 d. 22, "Protokol," p. 2.
} 
It also served a multi-purpose function beyond housing for children and workers, and met the state's cultural demands. In addition to bed rooms and classrooms, the home included a film room, a library, and place to practice physical culture.

Children themselves became aware of their environments and sensitive to their geographical surroundings and their transformations. In his memoir, Alex Saranin reminisced about his first day of school in 1926 . He described the placement of his school and the spaces in between: "We had to cover a distance of about a kilometer to reach the center of the village now known as Revolution Square. It occupied an area of about 5 hectares and was used for sports and celebrations of the October revolution and May Day..." ${ }^{98} \mathrm{He}$ also described the exterior of his school which was the first floor of a large old brick building "on the street side and square." 99 The ground floor was already occupied by a department store and village hall..."100 Again, Saranin's description of the school's site as a place of learning and celebrating reinforces the pragmatic and versatile nature of children's places in the Soviet Union. The placement of children's places was strategic in the sense that regardless of where in the empire they were located, they exposed children to political and cultural icons or sites on their everyday routes to school.

The most notable deviance between Kalmyk and Moscow children's internal rationally-planned spaces are those outside of state-led institutions, such as the home. Kalmyk sources scarcely refer to life in children's parental homes. In Moscow, however, with the aftermath of the Cultural Revolution (1928-1932), that overturned initial

\footnotetext{
${ }^{98}$ Saranin, Child of the Kulaks, 30.

${ }^{99}$ Saranin, Child of the Kulaks, 30.

${ }^{100}$ Saranin, Child of the Kulaks, 30.
} 
Bolshevik family policies where the state was the family, Soviet pedagogues turned to the home as an extension of a place for learning. Moscow officials, desperate to improve children's academic performance, advised parents to create "all the necessary conditions for a child's study." 101 The report justified this move by explaining how in the past children did not have the "necessary conditions to complete their homework," and therefore urged parents to create a nurturing and encouraging environment within the home. ${ }^{102}$ The absence of this advice in Kalmyk sources suggests Soviet imperial notions of ethnic superiority or suspicion of Kalmyks alleged 'cultural backwardness'. While Bolsheviks sought to modernize all spaces for children, some places (i.e., in Moscow) were already more "modern" than others (i.e., Kalmykia). Therefore, Kalmyk children, it seems, were better off acquiring Soviet values and education in state-led places such as schools or camps, rather than their deemed culturally backwards homes. Even in the classroom Kalmyk children confronted prejudice and experienced teases from their Russian classmates with "little ditties about the Kalmyks."103

Changes in the regional landscape, especially in Kalmykia, were most evident with the emergence and placement of new institutions and buildings for other cultural groups, such as the Muslim school in the Kalmyk Bazaar. ${ }^{104}$ The building of children's outdoor spaces in Kalmykia and Moscow resembled more than they differed in style,

\footnotetext{
${ }^{101}$ TsAGM, f. R- 528, o. 1 d. 70 Skhol'nyi sektor, Doklad Tov. Zolotukhina, zadach skhol'nyi i pionerskogo otriada i novom uchebnom godu ot 2 sentiabria 1933, 9.

${ }^{102}$ NARK, f. R- 25, o. 1 d. 116 “Doklady inspektorov”, p. 210-13.

${ }^{103}$ Harvard Project, Schedule B, Case 23, p. 6.

${ }^{104}$ NARK, f. R-25, o 1 d. 116, p. 210-13. The placement of the Muslim school reveals the consequence of the mapping of territories under the nationalities campaign, in which Bolshevik-appointed cartographers and geographers erroneously drew borders around heterogeneous ethnic groups.
} 
strategy, and function. In both Kalmykia and Moscow, officials built children's winter and summer camps, that held slightly different scheduled activities depending on the season. In Kalmykia, children were organized in kolkhozes (collective farms) in order to be engaged in 'natural work' during the winter. Children in the camps planted seeds and participated in physical culture-related activities. ${ }^{105}$ Moscow Children's Home No. (Number) 60 Krasnyi bogatyr' was strategically placed near the woods and river so that the children could play in the "natural rich environment." In the children's home, school directors designated places to foster nature-based activities such as planting and gardening. ${ }^{106}$ Children in Moscow's Krasnyi Bogatyr' engaged in more practical handson activities than Kalmyk children. Some of their activities combined both physical activities with engineering and conceptual ones. The children in Krasnyi Bogatyr' "chopped small wood pieces to construct a little fence and even small town of their own." ${ }^{\prime 107}$ The particular activity of chopping wood to build their own small towns combined geography and natural sciences, and allowed children themselves to participate in the planning (however big or small) of ideal Soviet places, an idea or practice that further emphasized the distinctiveness of a Soviet childhood, in which official discourse proclaimed children as the future builders of communism. Even if the activities slightly differed for children in Moscow/ European Russia and Kalmykia/Eastern Russia, outdoor camps held similar purposes as recreational place, taking on a more West-Russian-Soviet style. In fact, the actual ordered equipment inventories of two camps in Kalmykia and

\footnotetext{
${ }^{105}$ NARK, f. R 25, o. 2, d.188, “Spiski,” p. 17.

${ }^{106}$ TsAGM, f. R-528, o.1, d. 535 “Zapisi igr detey za 1937 god”, p. 1 .

${ }^{107}$ TsAGM f R-528, o. 1. d. 535, “Zapisi”, p.1.
} 
Moscow listed several identical items. Some of the items listed included a balalaika(traditionally Russian instrument), gramophones, checkers, chess, volleyballs, and parallel bars. These sports items reveal that not only did children experience collective activities such as learning, playing and exercising outdoors, but also engaged in the same types of artistic cultural activities that tended to be Russian or Western in fashion. ${ }^{108}$

Children's squares (or playgrounds, usually square spaces often built around residential buildings and schools) created spaces that were integral to children's upbringing that was related to a child's attitudes and morals at home. Soviet pedagogues regarded children's squares as places that promoted overall upbringing (vospitanie) and academic or scholastic learning (obuchennie), since it was located out outside of the school itself and extended the academic year. ${ }^{109}$ The late 1920s and 1930s marked a period where both Kamlyk and Moscow officials increasingly paid attention to the construction of children's squares.

Concurrent with Stalin's happy childhood campaign, these unique, designated child-friendly spaces became more ubiquitous over time. In 1927, Kalmyk officials called for the construction of two children's playgrounds (detskii ploshchady), that would provide a place for 15-20 children aged between 4-7 years old to run during the summer months in order to facilitate the preschool in the region. The creation of the children's square, with their careful planning and strategic placement in the community, was

\footnotetext{
${ }^{108}$ NARK, f. R- 92 o. 2 d. 10 "Svedenie Privolzheskogo,” p. 29. Also NARK, R-92, o. 1 d. 2 "Kylt'tovaryi.". And TsAGM, f. R- 528 o. 1 d. 216, "Otchet o provedennikh zimakh kannikul v shkolakh gor Moskvii v 1933-4," p. 5.

${ }^{109}$ NARK, f. R-92 o. 1 d. 11 "Smeta ulisnogo otdela narodnogo obrazovaniia, 1938". The definition for the terms vospitanie and obrazovanie were adapted from Felicity Ann O'Dell, Socialisation Through Children's Literature: The Soviet Example (Cambridge: Cambridge University Press, 1978), 5.
} 
another factor in the modernization of children's places in the Soviet Union. The report on playgrounds from the Derberovskaia ulus (district) in Kalmykia reinforces the notion of the children's square as a modern place and space in its conceptualization of a place to create a happy childhood and a common space for soviet socialization. It was also part of the Soviet 'modern' process in the way that Soviet officials only allowed professionals or individuals trained in courses from the "Department of Pedagogy" and elementary school teachers to work in the squares. Again, like the space of school, camps and homes, children's squares, being ran by professionals, adds to the idea of Soviet projects as scientific, rational spaces. ${ }^{110}$

Like their Kalmyk counterparts, Moscow officials developed a network of children's squares that aimed at keeping children busy during the summer months, open from morning to evening, with the help of the Pioneer organization. ${ }^{111}$ Just as children's homes served several purposes, children's squares, especially in Moscow, also held multiple functions. One Moscow newspaper reported that children's squares in the Proletarskii and Sokol'nicheskii districts transformed from playgrounds into sites of celebration during International Children's Week held in May 1928. According to the report, new activities took place such as "mass walks" by "unorganized, spontaneous" groups. ${ }^{112}$ Therefore, this new place went beyond its purpose of being a place of play and learning, but also of political awareness and celebration.

\footnotetext{
${ }^{110}$ NARK, f. R-95, o. 1 d. 23, "S delalim detskoi ploshchadki,", p. 11.

111 “Det Kommuni," Komsomol'skaia Pravda, August 19, 1929, p. 3.

112 “Mezhdunarodnaia detskaia nedeliia,” Komsomol'skaia Pravda, May 21, 1929.
} 
Excursions, though not concrete places, but activities that involved change of place, from urban sites of streets and museums to natural ones such as woods or parks created a new space that was well-planned and tended to have an agenda that encompassed both cultural and (anti-)religious education. In the case of early 1920s Kalmykia, school officials held excursions in the summer "warmer" months. According to local officials, excursions served a practical function "allowing children to learn about wildlife and their environment in the Volga region" (geography), and even learn hunting skills, a practice that is nowhere to be found in Moscow sources. ${ }^{113}$ Hunting, part of Kalmyk culture, reflects another factor in the Bolsheviks' attempt to combine their nationalities program with childhood development with excursion programs. ${ }^{114}$

Like in Kalmykia, excursions for children in metropole cities including Moscow and Leningrad were designed to reinforce children's practical knowledge as well as geography. Yet, excursions in Kalmykia tended to continue some Kalmyk traditions, such as hunting games and training. In Moscow, they usually served to break old Russian habits, particularly religious ones. One particular example of this can be extracted from a 1928 excursion reported in Komsomol'skaia Pravda, when local school officials planned a field trip for children in a Leningrad Home during Christmas time. The article advised other cities to follow Leningrad's example by taking children around the city in order for them to substitute Christmas with a more nationalist- Soviet experience. Rather than children celebrating Christmas at home with their families, school and children's homes directors escorted children around Leningrad in order to view prominent statues and sites

${ }^{113}$ NARK, f. R-25, o. 1, d. 116 "Doklady Inspektorov".

114 D.V. Muchkaieva, “Smobytnost' Kalmytskhikh Natsional'nyikh Igr," in Plus do Posle, Dec 2007. 
including the Hermitage, and the Detskoe Selo (Children's Village). ${ }^{115}$ Despite children's squares being places, or excursions being spaces for children's learning and enjoyment, the Bolsheviks manipulated these children's sites as an answer to counterrevolutionary activities such as celebration of Easter or Christmas and reinforce Soviet ideology. ${ }^{116}$

While Soviet local officials in Kalmykia and Moscow strategized indoor and outdoor places and spaces for children with rational, common, or universal designs for both Kalmyks and Russian children (or others in the Soviet Union), the Bolsheviks faced yet another challenge: what to do with children who were without a space or place to live - or rather-- those who were homeless? Throughout the 1920s (post- Civil War era) and even into the 1930s, Kalmyk officials strategized to seek help beyond Narkompros, and the all-Central Russian Executive committee by asking the local community to fund children's homes, especially after the Civil War. Even well into the NEP-era, Kalmyk officials continued to struggle with the homeless child problem and lack of funds: "In the Kalmyk Oblast "[we] have a large quantity of homeless children ...State help is too small" ${ }^{\prime 17}$ As a way to remedy this lack of funds and space issue for homeless children, Kalmyk officials proposed to raise funds by hosting spectacles, theatrical shows, lotteries, concerts, and film screenings throughout the region.

\footnotetext{
115 “Otkazhemsia ot prazdnovaniia rozhdestvo, ” Komsomol'skaia Pravda, December 7, 1928.

116 "Boii kul'turi s religiei: 500 predpriiatii rabotaii na paskhe", Komsomol'skaia Pravda, April 24, 1929. Also Saranin describes Easter celebration 1929 and how the Komsomol and Pioneers yelled at the church members to discourage religious celebration. Saranin, Child of the Kulaks, p. 30.

${ }^{117}$ NARK, f. R-95, o. 1 d. 13 "S perepiskoi o pomoshi besprizornaia detiam". According to the Ulus (district) Children's commission - Detkomissi, the definition of a homeless child fell into several categories including one who is without parents or relatives and those who lost connection with their relatives.
} 
Throughout the 1920s and 30s, Moscow, like Kalmykia, struggled with the besprizornye - or homeless child-- question, particularly with the staggering growth of street children in the early 1930 s as a result of the "liquidation of capitalist elements." In 1931, Moscow had 5,546 homeless children and in 1933, the homeless children population rose to over 20,000 . School officials reported in 1934 , that the number of homeless children reached as high as 180,000 . Rather than focusing on the place and construction of children's homes, the Organization of the Fight Against Homeless Children teamed with City Department of People's Education (Gor ONO) and designed a transport system. They added an organized militia to patrol the streets and take homeless children to a home while investigating their parents and relatives. ${ }^{118}$ Despite the City Education Department's (Gor ONO) efforts and 100,000 rubles-investment to construct sanatoriums, the report acknowledged that the construction was slow to come. In general, the growth of children's homes usually located in Moscow's city center did not provide enough room for the exponential rate of the rise of the homeless children population. ${ }^{119}$ Child homelessness was not the only obstacle officials in both localities struggled with. Even if the children were housed, the maintenance of children's institutions did not meet official standards of modernity, rational order, and cleanliness. As early as 1922, an inspector's report declared Children's Home no. 1 as unfit for children. It was "congested" and "so overcrowded that children lie every night on tables.", 120

\footnotetext{
${ }^{118}$ TsAGM, f. R -528 o. 1 d. 201, "Detski domov otchet (sektora okhrany detsvo borbe s detskoi besprizonostiu za 1930-1934 goda), p. 2.

${ }^{119}$ TsAGM, f. R -528 o. 1 d. 201, "Detski domov otchet (sektora okhrany detsva borbe s detskoi besprizonostiu za 1930-1934 goda), p. 2.

${ }^{120}$ NARK, f. R-25, o. 1, d. 116, "Dokaldy inspektorov", p. 2.
} 
The inspector insisted (as seen in pedagogical manuals for Kindergartens) to "isolate" or compartmentalize rooms, by building stairs in order to separate the facilities and rooms. Again, these suggestions were factors that would make the place more spacious, modern, and 'easy' for children. The report also noted the need to construct ovens to provide warmth for the children. Perhaps the largest complaint, that was also shared by reports in Moscow children's institutions, was the need to "practice careful cleaning in the kitchen." 121

The conditions of Children's Home No. 1 was not an isolated case in the Kalmyk Oblast. Children's Home No.2 suffered from "alien [unnatural] conditions" that made the environment "unsatisfactory" for work in the school. Besides "unclean conditions," the learning space and place of the classroom was "ill-equipped" and lacked class furniture for children. The inspector blamed the large percentage $(66 \%)$ of children's absences in school on the illnesses as a consequence of poor maintenance. Furthermore, the inspector lamented that the classroom, not resembling the ideal as shown in propaganda or advised in manuals, "lacked age-appropriate desks" and even instructive facilities that were "interesting" for children to help them learn. ${ }^{122}$ Porokh critiqued the local organ of Narkompros, which had its own economic branch to manage the Kalmyk populations' needs, and thus the funds for 'future education' were in last priority or often neglected. ${ }^{123}$ He argued that they could no longer afford the "weak attempts" of Narkompros in strengthening Kalmyk education and the need to improve schools to satisfactory level by

\footnotetext{
${ }^{121}$ NARK, f. R-25, o. 1. d. 116, "Dokaldy inspektorov," p. 2.

${ }^{122}$ NARK, f. R-25, o. 1. d. 116, p. 2.

${ }^{123}$ NMRK, V. Porokh, “Dokladu Zaprosi I Nuzhdy Narodnogo Obrazovaniia Kalmytskoi Oblasti, p. 35.
} 
$12 \%$ to maximum $15 \%$, describing in terms of material needs for the classroom. He added that as a result of neglect they acquired "poor quality tables." 124

The notion of the ideal and modern learning space and place in the Soviet Union continued well into the 1930s. Nationality schools in the Astrakhan region (mostly minority Tartar and Kazakh schools) were deemed as failures because of the lack of classroom equipment. In fact, the inspector attributed the children's "low performance" in academic subject as a consequence of the "lack of class furniture." He continued that “in the majority of schools, there are no chalkboards, nor teachers' desk, as well as no geographic maps." ${ }^{125}$ As late as 1938, during a meeting of the preparation for the 1938-9 academic year in Kalmykia, the organization of interior places was still important. The meeting leader advised "before the start of the school year, be sure that classroom furniture is a priority." ${ }^{126}$

While Kalmyk inspectors found dirty and ill-equipped children's places including homes and classrooms, inspectors of Moscow children's institutions echoed similar frustrations. Moscow school inspectors reported how children's homes, especially kitchens, were "dirty and full of smoke." 127 Even the library, a space and place intended to facilitate the modernization of the Soviet education system, failed in its purpose of being a space intended to increase academic progress. It also failed in providing children the experience to check out books, another practical skill that taught children the

\footnotetext{
${ }^{124}$ NMRK, "Dokladu Zaprosi”, p. 35.

${ }^{125}$ NARK, f. R-92, o. 2, d. 10, "Svedenie Privolzheskogo o likvidartsii negramotnostii, 1938”,p. 4.

${ }^{126}$ NARK, f. R-92, o. 2 d. 10, “Svedenie Griveosskogo,” p. 22.

${ }^{127}$ TsAMO, f. 2614, o. 1. d. 19, “Anketa.”
} 
workings of bureaucracy, as well as the collective experience of reading with peers in the same place. ${ }^{128}$ In addition to not meeting these goals, some school libraries were reported to have failed in their other function-- as a space of protection. According to party meeting notes in 1933 , the $18^{\text {th }}$ and $19^{\text {th }}$ schools in the October district of Moscow lacked "corners" for children to access books and read. In School No. 19, the director demanded the construction of a "separate room altogether" for books. Another school official reported that even though children stood in line for over half an hour, many would leave without books because the library would run out. The report continued to list the complaints stating that "the library itself should be a cultural institution. We have children sitting there for 3-4 hours keeping their coats on [because of the lack of heating]. We have dirty [conditions] because there is no maintenance. It is dark because there are no means to light the room." ${ }^{129}$ To conclude his observations on the deplorable conditions, the school official noted that "the [library] floors are cracked like a mirror... there is snow all around the kids," further emphasizing the need for the library to be a separate and well-maintained space. ${ }^{130}$ While Moscow schools tended to fail in meeting state requirements in providing reading rooms, in Kalmykia, primary schools did not even have libraries, but only a space known as a 'red corner,' in which students could find Russian classics and translated foreign literature. ${ }^{131}$ Although in official discourse the descriptors cold, dirty, dark, are more reminiscent of the terms used when referencing

\footnotetext{
${ }^{128}$ TsAGM, f. 528, o. 1, d. 78 "Stenogramma Konferentsii detskikh biblioteki o rabote bibliotek gorod Moskov ot 27 Ianvaria 1933”, p. 4.

${ }^{129}$ TsAGM, f. 528, o. 1, d. 78, p.4.

${ }^{130}$ TsAGM, f. 528, o. 1, d. 78, p. 4.

${ }^{131}$ Harvard Project, Schedule B, Case 23, p. 9.
} 
children's spaces and places in tsarist Russia (such as Porokh describes children's preRevolutionary schools without light), they became more commonplace descriptions for actual Soviet ones.

\section{CONCLUSION}

In the construction of a common Soviet childhood for children of the empire, space played a central role in shaping the place of the Soviet Union for all children. Regardless of ethnicity or nationality, Soviet pedagogues and officials designed spaces and places for children to help imagine their position within the Soviet Union as well as their community. Soviet pedagogues and local school officials intended for all children to understand the notion of the diversity in the Soviet state, where they would experience being diverse in nationality but common in Soviet socialism. Through textbooks, maps, and excursions, children would understand their surroundings and embrace the nineteenth-century imperialist concept of edinstvo mnozhestva.

However, these representations had another layer of discourse embedded within them - that of modernization and progress. Understanding their space through education, texts, geography, and the sciences in a rational way, was central to the project of Sovietizing the young Kalmyk, Tartar, or Great Russian. Modernization projects were not limited to the advancements in industry, technology or the social sciences, especially when designing or conceptualizing spaces for children. Places, concrete buildings designated for children such as children's homes, schools, libraries, camps, planned, scientifically-mapped, and carefully measured as derived from Lenin's mathematical 
conceptualizations of communal apartments. ${ }^{132}$ Science continued to be an important component in the construction of ideal places and spaces for children. For example, Soviet officials regarded electrification and light at schools and orphanages as essential to children's growth and facilitation of learning. It also served to reinforce the discursive break from the tsarist past, which Soviet propagandists referred to as dark, oppressive place and era. Despite the Bolsheviks' efforts to rapidly modernize Kalmykia or the Astrakhan region, especially in children's institutions, substantial industrialization did not take place in the region until roughly 1940, when a highway was opened between the Kalmyk capital Elista and Eivnaia. It was not until 1941 that a railroad system was constructed in the Astrakhan region. ${ }^{133}$

The purpose of Soviet strategic spaces and places for children was to instill one common Soviet childhood through one or several spatial experiences that children of different ethnic backgrounds would share - whether indoors or outdoors, or in the classrooms or camps. In the early revolutionary era, children in both Kalmykia and Moscow played in the common place of the children's square or learned in the classroom. Strategic placement of buildings or parks in the center of the city gave children more access to cultural and business settings. Meanwhile, camps and certain children's home's were constructed near woods and natural environments in order to improve their health and in both cases bring children 'closer' to their natural state, which reinforced the

\footnotetext{
${ }^{132}$ Yuri Slezkine, "The USSR as a Communal Apartment or How a Socialist State Promoted Ethnic Particularism," in Slavic Review, 53 no 2 (Summer 1994), pp. 414-452.

${ }^{133}$ Harvard Project, Schedule B, Case 23, p. 19.
} 
continuation of eighteenth-century modernist discourse. ${ }^{134}$ Strategies in designing children's places were not only relegated to where the particular building or park should be located. Soviet child specialists strategized to change them into 'spaces' with proSoviet, anti-religious or ‘backwards campaigns. Even in Kalmykia, children's everyday space changed with Soviet holidays, including celebrating October Revolution day at school. ${ }^{135}$ In fact, the first day of school itself was also an important holiday that marked a common rite of passage for each Soviet child that they experienced each September 1st. ${ }^{136}$ In terms of spaces and places of worship in Kalmykia, religious venues transformed over time. During an interview, a Kalmyk man reminisced about his childhood under the NEP era, when the Bolsheviks allowed people to continue attending church and practice their religion, but quickly changed this policy under collectivization with the arrests of Buddhist priests. Rather than completely transforming or succumbing to the 'socialist spaces' of soviet worship, when the temples closed or were transformed into restaurants, clubs, or schools, Kalmyks used their homes as religious sites and taught their children to pray at home. ${ }^{137}$ In fact, one Kalmyk man noted that "atheism was not at

\footnotetext{
${ }^{134}$ Notions of children as natural beings can be traced back to the writings of J.J. Rousseau and in particular Emile, or On Education trans. Allan Bloom (New York: Basic Books, 1979). Also see Philippe Ariès, Centuries of Childhood: A Social History of Family Life, trans. Robert Baldick (New York: Knopf, 1962).

${ }^{135}$ NARK, f. R-92, o. 2, d. 10 "Svedenie Privolgaskogo U ONO Kalmyk ASSR, 1938." The Kalmyk calendar before the October Revolution, as in other Asian cultures marked each year by observing a particular animal. Some examples of yearly names include Year of the Tiger, (Bar Zhil), to year of the Hare (Tulla Zhil), and Year of the Swine (hakha zhil). The beginning of the year marked the first calendar holiday Tsagan Sar. Also as in other Central Asian countries, one year consisted of twelve months where each month was also named after an animal, which characterized the type of work that was done according to the needs of the season. Even the seven days of the week had their own Kalmyk identifications, named after planets, such as Narn harg edr (Day of the Sun) Sar harg edr (Day of the Moon), and so forth. For more on Kalmyk holidays and culture please see: U. E. Erdniev, K.N. Maksimov, Kalmyki: Istorikoetnograficheskie ocherki (Elista: Kalmytskoe Izdatel'stvo, 2007), 381-382.

136 “Prazdnik Uchebyi” Komsomol'skaia Pravda, April 24, 1929.

${ }^{137}$ Harvard Project, Schedule B, Case 21, p. 9.
} 
all common among the Kalmyks except those who were besprizornye and who were not brought up at home." ${ }^{138}$ While the Bolsheviks regarded the space and place of the Kalmyk home or nuclear family as suspicious, the Kalmyks perceived the space outside of the nuclear family as dangerous to the culture's survival.

In Moscow, holidays also played a role in reshaping everyday space and place by reifying the Bolshevik victory of revolutionary progress and the eradication of backwardness. These manipulations of children's everyday places teach us that Soviet projects were not flawless in their implementation and had to be redesigned as local leaders continued to face some challenges from parents, maybe even children resilient to trade their traditional holidays for Soviet ones. Beyond serving as sites of soviet modernity in teaching and protecting children in the Soviet Union, the manipulation or multi-functionality of children's spaces - whether for fundraising, anti-religious campaigns, or shelter from the cold — was a consequence of Soviet culture or reality. These particular attributes were akin to the notion of a Soviet apartment as a compartmentalized space, where the rooms also served a multifunctional purpose in the sense that a living room was also a bedroom, or a kitchen a place to cook or a site of underground activities.

While Soviet discourse portrayed children's places as sites of learning and protection, not all children shared the same sentiments as their superiors. In her diary describing life under Stalin, Nina Lugovskaya did not necessarily see her school as a space and place for learning and acquiring socialist behavior. Rather, she viewed school as a place to play and with her classmates. Lugovskaya often boasted about missing

\footnotetext{
${ }^{138}$ Harvard Project, Schedule B, Case 21, p. 9.
} 
school to avoid doing class work and to escape the pressures of being what she referred to as the routine of "a clockwork." "139 Lugovskaya's diary highlights the tension between the space of the well-planned and rational school and the unofficial, irrational behaviors or activities that students engaged in, especially when not supervised. In Kalmykia, bolder children also expressed their disdain for the Soviet regime. One Kalmyk man recounted in his interview how in 1935 an older student, known to be the best student in school, "wrote the word vreditel' (pest/wrecker) between the portraits of Lenin and Stalin." The student's action defaced school property and manipulated his space in a negative way. ${ }^{140}$ In fact, after this incident he noted that the officials no longer hung portraits of the leaders in the classroom, thus showing how children can have an impact or manipulate the ideal space of the Soviet classroom.

Despite intentions to improve children's spatial experiences, the spaces and places scientifically constructed to create the Soviet childhood often failed to meet the ideal standards of the very concepts they were based from. Both Kalmyk and Moscow children's institutions suffered from inadequate spaces and lack of furniture, especially designed for children. Beyond material needs or child-friendly apparati, Soviet officials also became preoccupied with the cleanliness of a space and place. Clean and hygienic places were part of the Soviet modernization process discussed in the subsequent chapter. For many Soviet officials, lack of adequate space and furniture (in children's homes and schools) was one of the primary causes for children's absences and failures in school.

\footnotetext{
${ }^{139}$ Nina Lugovskaya, The Diary of a Soviet Schoolgirl, 1932-1937 (Chicago: Northwestern University Press, 2003), 28, 43.

${ }^{140}$ Harvard Project, Schedule B, Case 23, p. 6 According to the interviewee, the student who was 12 was arrested by the NKVD and sentenced to death. He added that this incident initiated a law that stipulated any student who is 12 years old and makes any anti-Soviet statements could be punished by imprisonment or death.
} 
Thus, age-appropriate furniture and places for children further reinforce or reflect the Soviet ideology and the ways in which spaces and places were essential to shaping childhood and designed to accommodate the Soviet idea of proper everyday life for children while fostering notions of socialization and collectivity.

In official discourses and propaganda, children's spaces in Moscow were represented as more advanced than their ethnic minority counterparts in terms of culture and the use of space and place. However, when investigating Kalmyk children's spaces in comparison with Moscow's, both localities shared more in common in terms of architectural and spatial planning, devising appropriate indoor, outdoor and imperial political spaces and places. Above all, Kalmyk and Muscovite children's spaces and places faced many of the same challenges due to historical realities, and lack of proper planning and funding as a result of the Civil War or the outright fiscal negligence on Narkompros to provide the needed funds.

For many Kalmyk children, however, the open place of the steppe and in general, Kalmykia as a whole was imagined as a safer and healthier place to live in than urban areas. Interviews with Kalmyk adults reminiscing about their everyday childhood experience reveal a common narrative of the benefits of the open place of Kalmykia especially without the interference of the Soviet government. One example comes from a man born in the Don area in 1915, who discussed the difficulties of his first years of primary school which was located in a large city near the Caspian Sea. He noted: "I was a bit disturbed by the bustle of the traffic and by the trolleys..."141 He also observed that

\footnotetext{
${ }^{141}$ Harvard Project, Schedule B-5, Case 15, p. 1.
} 
many students in the Soviet era contracted tuberculosis when they went away to study: "They went to the cities and study and left the steppe with its fresh air..."142

The chapter set the stage for how spaces and places for children were planned and executed- the context for subsequent chapters. As noted, cleanliness became a major drive for what constituted as ideal, modern space. The next chapter shifts focus from the manipulation of children's spaces and places to children's bodies, with a particular emphasis on hygienic routines, exterior dress and how these practices aided in the creation of a Soviet childhood.

\footnotetext{
${ }^{142}$ Harvard Project, Schedule B-5, Case 15, p.11.
} 


\section{CHAPTER III: A CHILD'S HEALTH IS DEPENDENT ON DISTORTIONS OF THE}

\section{BYT: PHYSICAL CULTURE, DRESS, AND HYGIENE IN EARLY SOVIET RUSSIA}

In a 1936 conference held for workers of children's homes in Moscow the announcer declared that "The fight for Cultural Upbringing - demands absolute full sanitationhygienic minimum in each children's home institution," arguing that in children's bodies and hygiene are being neglected. ${ }^{143}$

From their inception as a government body, the Bolshevik regime confronted medical issues from how to handle common ailments such as serious disease outbreaks resulting from Civil War, and rehabilitating the population from crisis and famine. The Bolsheviks also needed to teach the population new hygienic routines in order to prevent future medical challenges and eradicate old superstitious and traditional medical practices. In their first attempt to modernize public health, the Bolsheviks dissolved the pre-revolutionary office of the Ministry of Health and established the Commissariat of People's Health or Narkomzdrav. Headed by N.M. Semashko, Narkomzdrav created a more centralized organ that established new medical centers, and started medical programs that educated the population in acquiring new, 'modern', and proper hygienic routines that were essential characteristics to the Soviet citizen identity, especially for the younger population.

In the same way that the Bolsheviks conceptualized and rationalized space for children as another factor of modernizing Russia and the Soviet Union, they saw hygiene and the child itself as a litmus test and tool for further enhancing and progressing the Soviet child citizen (and indirectly, the state, nation, and empire). In short, children's

${ }^{143}$ TsAGM , f. 528, o. 1, d. 416 "Stenogramma konferentsii rabotnikov detskikh domov, o poriadakh, trudovii obuchenie i grammotnosti-vospitanikov v detskikh domakh ot 7 aprelia 1936," p. 13. 
became one way in which Soviet cultural projects attempted to refashion subjects into modern, clean and pure embodiments of progress and light. Through hygienic routines, Soviet pedagogues, pediatricians, and children's institutional directors instilled a sense of uniformity for both Russian and non-Russian populations. Children became objects of state-driven health campaigns, that were linked to citizenship in terms of outwardly appearance in dress and cleanliness, and internally through self- discipline and routinization of their own hygienic practices. However, as was the case with spaces, Soviet planning in both Moscow and Kalmykia struggled to meet state standards in care for children's health making the projects of state building between the Moscow and the Soviet Republics more similar in the path of revolutionary modernization than prevailing scholarship claim. ${ }^{144}$

Scholarship on health and medicine in Russia tend to overwhelmingly focus on sexuality and the body through different approaches, including discourse analysis. In the early 1990s, with the accessibility to Soviet archives, there was a proliferation of studies on the Soviet health system. All of the scholarship, including those on late imperial Russia, agree that the rise of health and hygienic discourses on the body were part and parcel of the modernization process. This is especially the case in the context of the Soviet Union, when the Bolsheviks consciously designed and allocated resources to health and medicine, as a vehicle for its Marxist/revolutionary path towards modernity and socialism.

The early Soviet health system began with the dissolution of the Ministry of Health and the establishment of the RSFSR Commissariat of Public Health

\footnotetext{
${ }^{144}$ Here I am referring to Starks and Michaels.
} 
(Narkomzdrav) in 1918. The creation of Narkomzdrav exhibited the Bolsheviks' selfconscious path towards modernity. By revamping the health care system, the Bolsheviks argued that it was a more rational, scientifically-based government body than its tsarist predecessor. The role of health campaigns also transformed the health system by addressing the country's health problems, and teaching the population to take more responsibility for their bodies. In keeping with the scientific and rational refashioning of the health system, official discourse proclaimed the role of the doctor from "doctor-as biological specialist" to a "sociologist," during the campaign of sotsial'naia gigena. The sotsial'naia gigena campaign marked the Soviet origins of health as a public issue, placing the emphasis on preventing diseases rather than curing them. ${ }^{145}$

The state's attention to health and the body, however, predated the revolutionary period and was a late nineteenth-century pan-European phenomenon, in which notions of purity and the health of the nation were major concerns especially in England and Germany. ${ }^{146}$ In Russia, the professionalization of medicine increased public opinion in health matters- particularly with the apprehension towards prostitution and abortion-and was a marker of the late imperial era's drive for modernity. ${ }^{147}$ Studies on the body in the Russian context, continued to focus on medical discourses, especially those

\footnotetext{
${ }^{145}$ Susan Gross Solomon, "Social Hygiene and Soviet Public Health" in Health and Society in Revolutionary Russia eds. Susan Gross Solomon and John F. Hutchinson, (Bloomington: Indianan University Press, 1990), 175.

${ }^{146}$ Kathleen Canning, Languages of Labor and Gender: Female Factory Work in Germany, 1850-1914 (Ithaca: Cornell University Press, 1996); Nancy R. Reagin, Sweeping the German Nation: Domesticity and National Identity in Germany, 1870-1945 (New York: Cambridge University Press, 2007); Nadja Durbach, Bodily Matters: the Anti-vaccination Movement in England, 1853-1907 (Durham: Duke University Press, 2005).

${ }^{147}$ Laura Engelstein, The Keys to Happiness: Sex and the Search for Modernity in Fin de Siècle Russia (Ithaca: Cornell University Press, 1992).
} 
concerning women and representations of the female body vis à vis social morality. The relationship between hygiene and morality was evident especially when nineteenthcentury Russian society approved representations of the maternal, fertile peasant woman in comparison with the Westernized woman who was seen as decadent and immoral. ${ }^{148}$ Yet, political and social preoccupations with the body did not end in late- $19^{\text {th }}$ century tsarist society, but continued well into the Soviet period. Initially, scholars perceived the Soviet stance on the body as puritanical and asexual. Recently, though, scholars have found that the opposite is true, that indeed discussion and discourses about sexual behavior was prevalent in early Soviet society and especially directed towards the youth. ${ }^{149}$ The historiographical trend of redefining the periodizations and categorizations of Soviet sexuality have debunked old notions of the Soviet liberal 1920s under Lenin, and repressive Stalinist 30s. In actuality, the sexual knowledge acquired in the 1920s "paved the way for the state's adoption of repressive policy towards sex in the 1930s." Regardless of their overall arguments, all scholars on Soviet health and the body tend to agree, using Foucault's theory on professionalization of the sciences (especially

\footnotetext{
${ }^{148}$ Sexuality and the Body in Russian Culture, eds., Jane T. Costlow, Stephanie Sandler, Judith Vowels (Stanford: Stanford University Press, 1993). In the collection Sexuality and the Body in Russian Culture, scholars defined sexuality and the body not as concrete objects/ events, but as discursive entities that historical actors wrote, imagined, conceptualized. While the authors argue that sexuality is both 'symptomatic and constructed by culture,' they fail to give a clear definition for the body.

${ }^{149}$ Gregory Carleton, Sexual Revolution in Bolshevik Russia (Pittsburgh: Pittsburgh University Press, 2005). Also see Igor Kon, The Sexual Revolution in Russia: From the Age of the Tsars to Today, trans., James Riordan (New York: Simon \& Schuster,1995). Kon's The Sexual Revolution is first comprehensive study of the subject published in both Post-Soviet Russia and the West.

${ }^{150}$ Frances Lee Bernstein, The Dictatorship of Sex: Lifestyle Advice for the Soviet Masses (DeKalb: Northern Illinois Press, 2007), 6. Also see: Donald Filtzer, The Hazards of Urban Life in Late Stalinist Russia: Health, Hygiene, and Living Standards, 1943-1953 (Cambridge: Cambridge University Press, 2010). In his study, he explores the problems of late Stalinist health drives which were virtually nonexistent. The government failed to collect trash and as a result there was a resurgence of early Revolutionary public diseases such as typhus.
} 
medicine) were "key factors of the modern state with intervention in the lives of people, mobilization and surveillance." ${ }^{151}$ In addition, another factor used in Foucauldian statebuilding theory was the way in which the Bolsheviks (at least discursively) called for or idealized the self-reliance of the masses: "The Health of the Workers is the task of the workers themselves." ${ }^{152}$ In other words, the individual would take more responsibility in the proper care and hygienic practices of his or her own body.

These discourses reflected the relationship between the health of the individual and the health of the state were widespread and disseminated through propaganda during the Soviet health campaigns of the Revolutionary era. The health campaigns also reflected the Bolsheviks' desires in state-building. According to Tricia Starks, "the cleansed body was not just a building block of the socialist utopia; it became the material manifestation of the revolution's success." ${ }^{\prime 53}$ While the Bolsheviks' promoted ideals of personal hygiene, state-led discourses on cleanliness were fraught with contradictions and complexities. For example, Soviet officials perceived dirty individuals as suspicious or un-Soviet, while conversely, the population resisted these claims and some even regarded wearing neat clothes as bourgeois behavior. ${ }^{154}$

However, as recent scholarship has shown, the Soviet health movements were not a solely top-down phenomenon, but have also been contested and reshaped from below.

\footnotetext{
${ }^{151}$ Bernstein, The Dictatorship of Sex, 7.

${ }^{152}$ Bernstein, The Dictatorship of Sex, 101.

${ }^{153}$ Tricia Starks, The Body Soviet: Propaganda, Hygiene, and the Revolutionary State (Madison: University of Wisconsin Press, 2008), 6.

${ }^{154}$ Starks, The Body Soviet, 199.
} 
Soviet officials' interactions with peasants, for example, have initiated reformulating laws including redefining biological markers of sexual maturity. ${ }^{155}$

Very few scholars have paid attention to the medical revolutionary projects outside of European Russia. One such work that combines the understudied scholarships of Imperial politics and medicine is Paula Michael's Curative Powers, which looks at the ways in which health and medicine became a conduit for imperialist projects in Central Asia, taking Kazakhstan as its case study. ${ }^{156}$ Michaels claims that the Soviets' methods of using medicine as a way to exploit its populations of the region to establish legitimacy is more similar to Western tactics. Following the trend of Soviet historians, Michaels argues that only European Russia came closest to meeting the revolutionary medical ideals and plans. ${ }^{157}$

There is still no significant study on children's and health and hygiene in the context of Imperial or Soviet Russia. The closest comes from Catriona Kelly's 2006 essay that focused more on the everyday lives of children through the implementation of schedules, time tables and new routines that would imbue them with new Soviet habits in

\footnotetext{
${ }^{155}$ Dan Healy, Bolshevik Sexual Forensics: Diagnosing Disorder in the Clinic and Courtroom, 1917-1939 (DeKalb: Northern Illinois Press, 2009).

${ }^{156}$ Paula A. Michaels, Curative Powers: Medicine and Power in Stalin's Central Asia (Pittsburgh: University of Pittsburgh Press, 2003). Tricia Starks also makes similar arguments in that only major urban areas came close to any of the revolutionary ideals regarding health and hygiene-- this chapter will contest this point by showing a comparison between the metropole and the periphery. For more on Soviet health and empire, see Cassandra Marie Cavanaugh, Backwardness and Biology: Medicine and Power in Russia and Soviet Central Asia, 1868-1934 (New York: Columbia University Press, 2001).

${ }^{157}$ Michaels, Curative Powers, 48.
} 
the ways that teachers and directors managed children's bodies during school and monitored time spent in the bathroom as well as hygienic routines. ${ }^{158}$

A discussion on children's health and hygienic routines are not solely based on bathing and cleanliness, but also extends to fashion and dress. Sumptuary laws and dress codes pre-dated the Revolutionary era and have their origins in Petrine Russia. Peter the Great enacted sumptuary laws to distinguish social classes and introduce Western European mannerisms into the Russian court. ${ }^{159}$ These practices continued well into tsarist Russia as the state controlled what men should wear, which altered throughout the nineteenth century according to Russia's relation to the West. ${ }^{160}$ These pre-Soviet laws on dress were not limited to European Russia, but were also part on imperialist ventures, and state- led conversions. For example, seventeenth-century missionaries and fur traders required Siberians to change their dress habits when they conformed to Orthodoxy — thus representing an aspect of tsarist Russia's nationalization, or Russification projects. Imperial law required that Russian Siberians their shave heads and wear German fashion, while native Siberians were distinguished with Russian fashion making them more honorable than their peers.

Again, very little is studied in terms of Russian children and dress. In the early Soviet era no compulsory uniform was in place, except for of course, the iconic Pioneer

\footnotetext{
${ }^{158}$ Catriona Kelly, "Shaping the Future Race: Regulating the Daily Life of Children in Early Soviet Russia," in Everyday Life in Early Soviet Russia, eds., by Eric Naiman and Christina Kiaier,(Bloomington: Indiana University Press, 2006), 256-281.

${ }^{159}$ Christine Ruane, "European Fashion in Russia" in Picturing Russia: Explorations in Visual Culture, ed. Valerie Kivelson and Joan Neuberger (New Haven: Yale University Press, 2008),119-123.

${ }^{160}$ Olga Vainshtein, “Russian Dandyism: Constructing a Man of Fashion.” In Russian Masculinities in History and Culture, ed. Barbara Evans Clements, Rebecca Friedman, and Dan Healy, (Houndsmill: Palgrave, 2002),51-75.
} 
uniform, which included the red scarf blue shorts and white shirts for boys and blue skirts and white shirts for girls. However, there were cases in the early Soviet period that some city schools did implement uniform codes especially for girls, which denoted school prestige. It was not until the 1940s that Russo-Soviet school systems implemented uniforms. ${ }^{161}$

The Soviet programs of health and hygiene embedded in official discourses reveal how children's bodies became the objects of the state-driven hygienic medical, routinized practices. Healthy and pure bodies were linked to citizenship and were important characteristics of defining a proper Soviet child, regardless of ethnic background ${ }^{162}$ As was the case for Western European nations in their imperial and state-building and societal projects, Soviet doctors and social workers focused on the sciences and biology to define citizenship and exclude those who did not conform to the prescribed biological norms (such as racial skin tones or facial measurements). Because of the nationalities campaigns, however, Soviet citizenship for both adults and children went beyond biological traits and features and included common hygienic habits and uniformity in dress. Soviet identity for children in terms of health practices were primarily the adult's responsibility, including teachers, pediatricians and in rare cases, parents. Despite it being the adult's responsibility to oversee children's hygienic practices and medical care, the main goal for Bolsheviks and pedagogues was for children to conform to and become self-regulate in hygienic routines, dress, and other bodily care practices.

\footnotetext{
${ }^{161}$ Catriona Kelly, Children's World: Growing up in Russia, 1890-1991 (New Haven: Yale University Press, 2007), 508-509.

${ }^{162}$ Kathleen Canning makes similar arguments in her study Gender History in Practice: Historical Perspective on Bodies, Class, and Citizenship (Ithaca: Cornell University Press, 2006).
} 
For the Bolsheviks, and especially under Stalin, children's happiness and wellbeing became a state goal. It also was a litmus test for the success of revolutionary projects, such as the eradication of child labor. By claiming that child labor was prohibited under Soviet law, the Bolsheviks distinguished themselves from the Western governments in their failure to protect children's bodies from the dangers of the factory floors. ${ }^{163}$

An examination of state-driven campaigns and attempts to revolutionize children's health and dress provides another glimpse of how Soviet officials intervened in children's everyday lives in order to establish a uniform childhood and a united imperial system. Soviet-based ideologies of the body and hygiene related to ideals of citizenship for children. State-published newspapers and pedagogical tracts emphasized the notions of purity, self-sufficiency, and discipline as ideals for the Soviet child to reach including, dress and physical culture. However, official culture and state laws were not the sole media forms that aimed at transforming children's hygienic routines. The everyday attempts of pedagogues and inspectors contributed and perpetuated the state's projects in shaping children's bodies to state ideals of cleaning the body inside and out.

\section{HEALTHY CHILDREN, FUTURE WORKERS}

"We must produce a new generation of healthy and buoyant workers, capable of increasing the power of the Soviet Union."164 (Stalin)

\footnotetext{
${ }^{163}$ For more on the social body and Foucault biopolitics, please see: Martin Hewitt, "Biopolitics and Social Policy: Foucault's Account of Welfare," Theory, Culture, and Society 2, 1 (1983): 67-84. In relation to protecting children's bodies from harmful places, as discussed in the previous chapter, the social body (which entailed a happy and healthy child) could be linked to the 'moral social spaces' in that the Soviets intended to protect children indoors while those who were outdoors, outside of children's institutions managed by state workers were considered a threat to society and even the state.

${ }^{164}$ Quote by: Joseph Stalin, "Children of the Soviet Union,” USSR in Construction, no. 6, 1935.
} 
In the early stages of the Revolution, Bolshevik leaders were cognizant of the important relationship between children's health and the growth of the bourgeoning socialist state. Although, discourses promoted state unity among the ethnically heterogeneous population, propaganda depictions of practices in dress and hygienic routines also included subtle (and at times not-so-subtle) racial undertones. Despite these contradictory images and texts, Soviet child specialists understood all children's bodies as essential in the success of state-building and another component of modernization.

The Bolsheviks' impetus to modernize the country in relation to the care of children's bodies was supported by scientific, rational knowledge. Children's health experts were also aware of the external conditions and environments that would impact a child's physical and mental well-being. Furthermore, they acknowledged the importance of the children institutions' role in ensuring proper instruction of health practices among younger children. In fact, children's health manuals reinforced Soviet notions of conformity through hygienic practices and dress. Morozova emphasized that: "The younger the child, the more important the conformity to the features of his physical and psychological personality, and the institutions for children of preschool age."165

To further emphasize the Bolshevik program of modernizing and professionalizing child care, Soviet tracts proclaimed that doctors working with children must be specialized in different forms of medicine and pediatrics, in order to cure infections in homes and develop regiments and secure a child's proper growth. ${ }^{166}$

\footnotetext{
${ }^{165}$ M. Ya. Morozova, E. I. Tikheeva I dr., Sovremennyi Detskii Sad: ego Znachenie i Oborodovanie (Petersburg: Gosudartsvennoe Izdatel'stvo, 1920), 61.

${ }^{166}$ Morozova, Sovremennyi Detskii Sad, 81.
} 
The ideal that these specialists strove for was child purity in cleanliness (like the adult counterpart) that was a conduit to achieve Cultural Enlightenment (prosvetlenie). For the Bolsheviks, one of the ways to reach Cultural Enlightenment and physical and psychological purity started with a child's self-sufficiency and self- discipline in hygienic practices.

The transformation of children's everyday lives came in the form of state-led interventions including new schedules and routine exercises, intended to instill "proper" habits. ${ }^{167}$ Soviet pedagogues advised Kindergarten and school directors to expect children to come to school clean. They warned, however, if parents dropped children off unclean, school directors were to instruct children to wash themselves before entering. These hygienic cleansing practices also extended to being a part of eating rituals, where children were required to wash their hands before every meal and rinse their mouths afterwards: "[These practices] should all be automatic within children, [performed] without protest and foundational [in their behavior]. ${ }^{\prime 68}$ These state-mandated hygienic routines intended to instill in the Soviet child's early years a sense of self-discipline and purity as expected in the ideal citizen.

Understanding the challenges that Kindergartens and school officials might have faced when teaching especially young children hygienic routines, specialists advised instructors to make these practices into games that would appeal to children. ${ }^{169}$ Outside of school, hygienic discipline was reinforced in sanatoriums and pioneer camps. In

\footnotetext{
${ }^{167}$ Catriona Kelly, "Shaping the Future Race," 259.

${ }^{168}$ Morozova et al., Sovremennyi Detskii Sad, 65.

${ }^{169}$ Morozova et al, Sovremennyi Detskii Sad, 81.
} 
addition to providing a place of leisure and social behaviors as discussed in the previous chapter, these outdoor camps were to ensure children's discipline in health, providing them with a "tanned look," and desired outward appearance especially the allocation of their "clean clothes" by camp organizers. ${ }^{170}$

While there were no official school uniforms in place throughout the Soviet Union until the 1940s, Soviet artists conceptualized ideal fashions for children as early as 1919. Just as early Soviet adult fashion was comfortable, and easy to work in, so were Soviet children's clothing concepts. Early Soviet conceptual children's wear were gendered: girls' uniforms included skirts while pants and ties were idealized for boys. Despite these gendered differences, all other factors in early Soviet children's clothing for boys and girls were more similar to each other in the way that the clothing was to have less restriction on children body. Soviet pamphlets expressed that the ideal child's clothing would be made of "woolen material" and "shapeless" in the way it should not accentuate biological features. ${ }^{171}$ Children's dress was also carefully regulated by doctors. In fact, pedagogical treatises claimed that "the hygiene of children's clothing is of paramount importance" - especially in terms of the quality of the material and the sharp, clean appearance. They recommended that school directors should carefully plan space and room for a child to independently dress and undress himself, and be able to freely reach his or her own clothes. ${ }^{172}$ By making areas designated to have clothing and

\footnotetext{
170 “Deti Kommunyi," Komsomol'skaia Pravda, June 26, 1929, p. 3.

${ }^{171}$ V.P. Akhmetev, Ikusstvo v butu: 36 tablits: Igrushka, Odezhda (TsI K SSSR I VTsIN, Izvestyi ca?), tablitsa no 29 "Skhol'noe plat'e."

${ }^{172}$ Morozova et al., Sovremennyi Detskii Sad, 65.
} 
accessories more accessible to children, Soviet pedagogues regarded dress as another factor, in addition to hygiene, in instilling self-discipline in children.

While early Soviet pedagogues warned school directors to be vigilant of unclean children's bodies, they also explained the importance of maintaining proper and clean clothes:

"whoever works in relation to children knows how much harm can be done to a child's body with dirty clothes. We can see how dirty shirts with missing sleeves, dirty sweatshirts, missing gloves and dirty shoes" could lead to frost bite in children's hands and legs which "could be beyond the doctor's scope of help." 173 Regulations to help protect children particularly stress that their bodies should never experience cold and their body temperature should be maintained at comfortable levels. Comfort was not limited to maintain body temperature but to ensure that children's clothes did not constrict any part of the body and be free -flowing.

Over time, and especially in the 1930s, ethnically Russian children were portrayed wearing these 'standard' models of scientifically-planned fashions, including ties and white button-down shirts. Children from other Republics (particularly non-Slavic republics) in contrast, in keeping with the nationalities campaign were portrayed as wearing traditional clothing, representing their ethnic background. However, Soviet propaganda depicted non-Slavic children's clothing according to the child's biological sex. For example, propaganda journals and newspapers often published photos or

\footnotetext{
${ }^{173}$ Morozova, Sovremennyi Detskii Sad, 77.
} 
illustrations of Uzbek or Kalmyk girls in bright, long colorful dresses with elaborate Central Asian-style head pieces. ${ }^{174}$

Figure 2: Girl Playing Instrument Wearing Traditional Kalmyk Clothing ${ }^{175}$ :

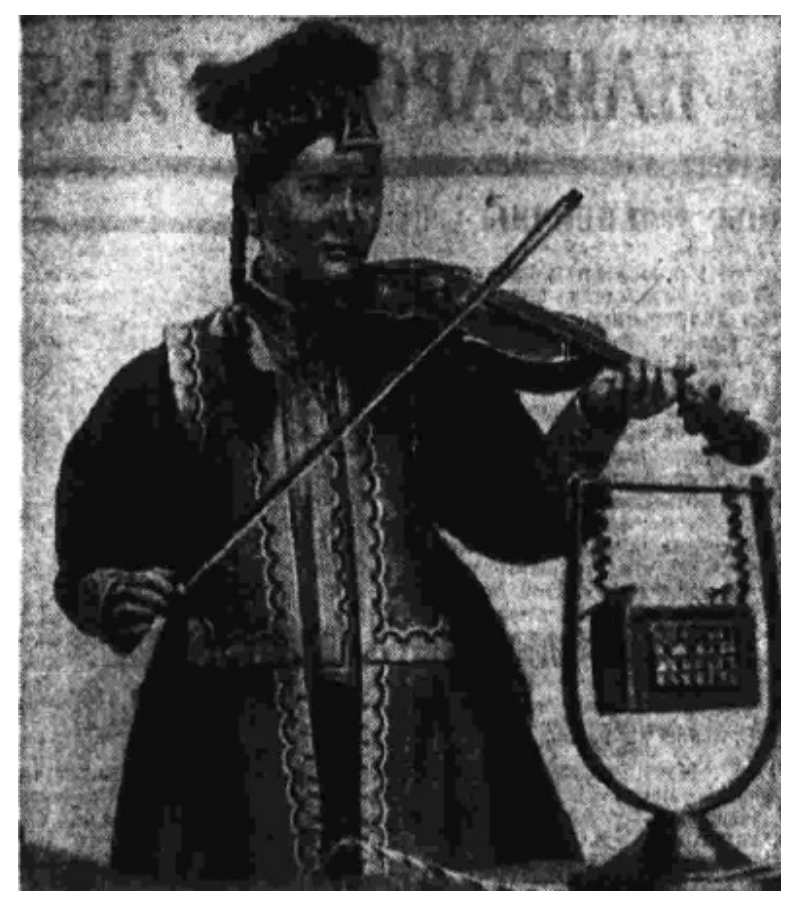

Non-Russian boys, as opposed to girls, tended to be photographed and portrayed in propaganda journals in shorts and tank tops. In a photo of an early Kalmyk Kindergarten the children wore oversized shirts and tank tops which became a kind of standard in Soviet casual wear, as they were also seen in Russian Kindergarten photos. The casual style of young children's clothing in early Soviet Russia was a stark contrast to prerevolutionary Kalmyk (Imperialist schools) where children were in full-dress military style uniform. The reflection of girls wearing traditional ethnic clothing as opposed to the

\footnotetext{
${ }^{174}$ Examples of this can be found in the following: "Tadjik Soviet Socialist Republic," USSR in Construction, no. 3, 1938; "Kirghiz Socialist Republic," USSR in Construction, no 71938 ;"Children of the Soviet Union" and "Oblastnaia Kolkhoznaia Olimpiada Kal'myiki" in Pravda, October 20, 1935.

175 “Oblastnaia Kolkhoznaia Kalmykii ...mnogo talantlivikh muzikantov,” Pravda, 20 October 1935, No. 290, p. 4.
} 
boys reflects one aspect of Stalinist culture and the retreat to pre-Revolutionary norms, especially in gender practices. ${ }^{176}$

Figure 3: Pre-Revolutionary Kalmyk Boys' Uniform (Presented in accordance with Fair Use Law 17 USC section 107) ${ }^{177}$ :

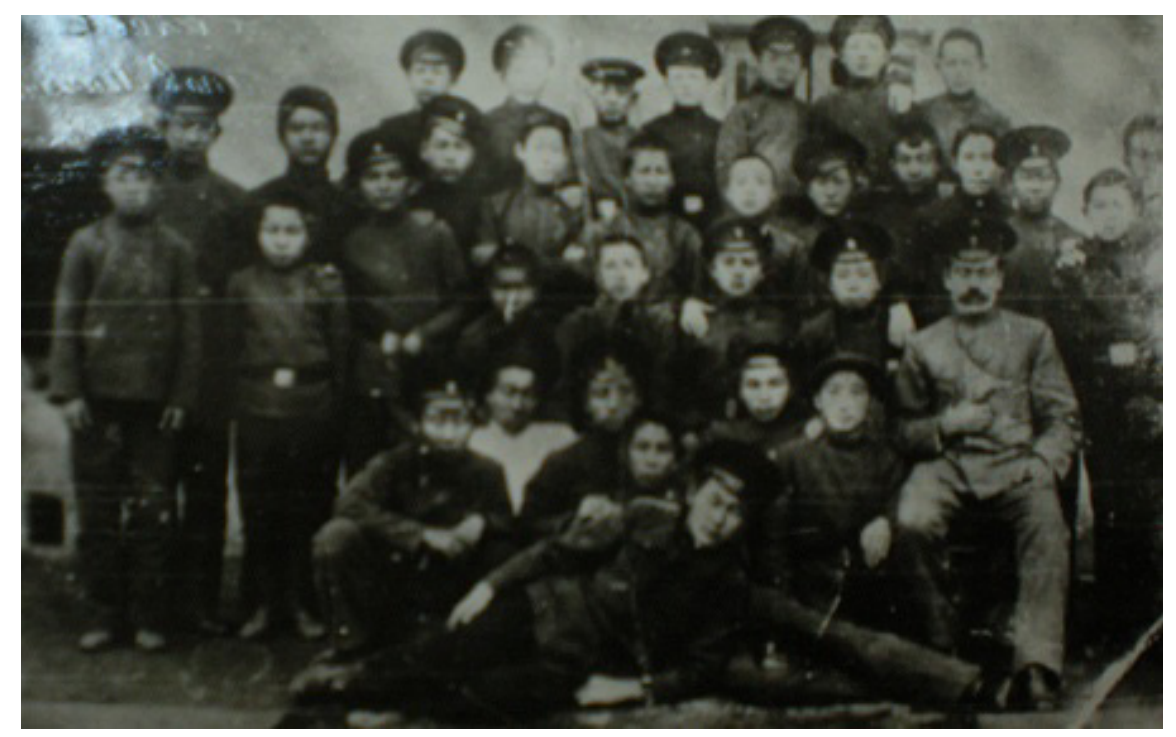

\footnotetext{
${ }^{176}$ Gender and family relationships transformed dramatically under Stalin. Stalin's Cultural Revolution glorified motherhood and reverted the family structure to the pre-Revolutionary model with the nuclear family as the primary institution or care-givers of children, as opposed to the State. The Great Retreat under Stalin also included more traditional gender roles for women as maternal figures and keeper of the homes. For more see: David L. Hoffmann, Stalinist Values: The Cultural Norms of Soviet Modernity, 1917-1941 (Ithaca: Cornell University Press, 2003), 88-117 and Wendy Z. Goldman, Soviet Family Policy and Social Life, 1917-1936 (Cambridge: Cambridge University Press, 1995).
}

${ }^{177}$ NMRK, N. 3457/ 2, 1916. 
Figure 4: Early Revolutionary Kalmyk Boys' Clothing (Presented in accordance with Fair Use Law 17 USC section 107): ${ }^{178}$

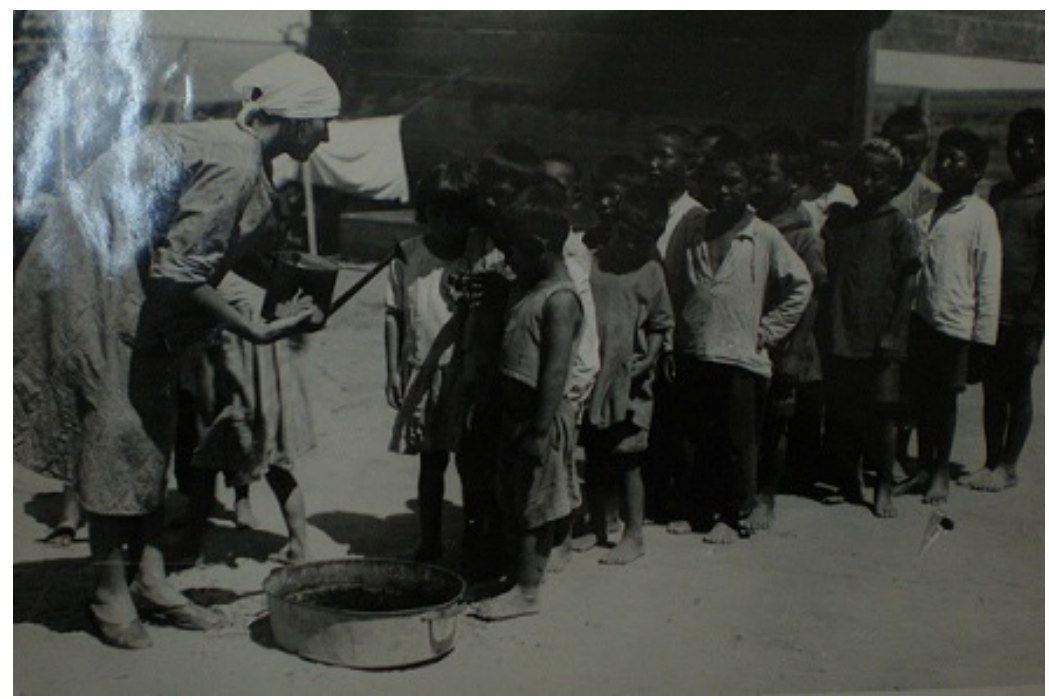

Making dress a marker or identity in ethnic children also reflected the ideology of edzhinstvo mnogo - out of one many - mnogo edzhinstvo - out of many one, as discussed in the previous chapter. The image of children dressed in their traditional ethnic outfits perpetuates Stalin's campaign of the Friendship of the Peoples, which reinforced the multi-ethnic unity policy promoted in the nationalities campaign. This claim included the Leninist-Marxist ideal of the worldwide revolution and endorsed the idea that the Soviet Union was an inclusionary state (empire) as opposed to its Western capitalist and imperialist counterparts. The portrayal of children in their traditional dress also reinforced the Soviet discourse in distinguishing itself into being a more 'youthful' 'modernthinking' country. By constantly using images and propaganda featuring children in Soviet-style clothing understood as clean and modern, they become the symbolic representation of the young and growing country.

\footnotetext{
${ }^{178}$ NMRK, N. 1457/ 7 “Rebiata Kalmykii Umivaiutsia v detskii sadu,” 1932.
} 
By closely comparing children's wear between Great Russian and non-Russian ethnicities, the ideals of Soviet modernity, progress and the future of the communist state belonged to ethnically Russian children. The norm depicted in Great Russian children's dress included sharp clothes and technological accessories such as bikes and watches on their body proper. ${ }^{179}$ One notable exception to this was in regards to non-Russian children who were not residents of the Soviet Union. For example, in keeping with the rhetoric of the "oncoming" world-wide revolution, the front page of a 1929 issue of Komsomol'skaia Pravda featured an African-American child who arrived to the international child's conference in Moscow, wearing the pioneer uniform of a white shirt, blue shorts and a red scarf. The portrayal of children in other parts of the world (outside of the Soviet Union) wearing Soviet-based uniforms was, for the Bolsheviks, evidence of Soviet progress in building communism around the world. ${ }^{180}$

\footnotetext{
179 “Watches, Bicycles, and Grammophones," USSR in Construction , no. 7, 1935.

180 “Programma Mirovoi Revolutsii," Komsomol'skaia Pravda, August 10, 1928, p. 2.
} 
Figure 5: Example of Kalmyk and Russian Children in Pioneer Uniform (Presented in accordance with Fair Use Law 17 USC section 107): ${ }^{181}$

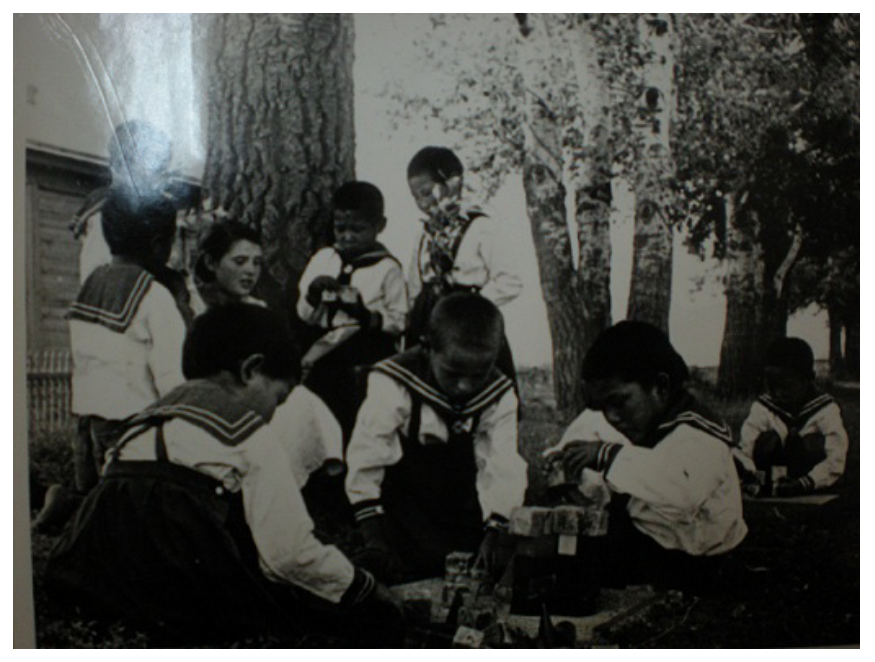

While Stalinist propaganda depicted non-Russian children and youths wearing their nationality fashion throughout the 1920s and 30s in the cases of Kalmyk children's homes, such as Children's Home No. 1 Kireev, items listed in children's clothes orders resembled more of the 'official standards' such as cotton clothes, dresses, shirts, aprons, scarves, and tunics. ${ }^{182}$ In the 1922-23 academic year, the children's home director was preoccupied in ordering brand name clothing, especially for girls' "uniforms" in the summer and winter months, amounting to a total of 3,000 ordered, aprons and over shirts, thus making Kalmyk girls' wear increasingly Sovietized and less traditional. ${ }^{183}$ In preRevolutionary Kalmykia, children's clothing tended to be made from warm materials to maintain body heat, parents usually exposed their children to the sun, with a hat for

\footnotetext{
${ }^{181}$ NMRK, KP 1133/25, "Pioner lager," 1936.

${ }^{182}$ NARK, f. R-25, o. 1. d. 262 “Spiski vospitannikov detdoma,” p. 186.

${ }^{183}$ NMRK, KP 2174/44 "Kratkyi otchet o rabote Kalm ONO.”
} 
protection. ${ }^{184}$ In general, children's clothing resembled closely to those of their parents'; girls wore long brightly -colored, full-length robe dresses, wearing her hair in two pigtails which signified her girlhood, adorned with a pointed, multi-angled hat, (in brides this was a conical shape made out of cloth called shivirliki) while boys were dressed in long tunics or dressing gowns called beshmet in Kalmyk, held with a belt while they protected their feet with knee-length boots. ${ }^{185}$ While these pre-Revolutionary dress and costumes were promoted in 1930s propaganda, in their everyday lives, children actually wore clothing that conformed more to Soviet culture—-such as the Pioneer Uniform. According to one Kalmyk man living under Stalin, Kalmyk customary dress "disappeared under the Soviets." 186

In the 1930s, even with the heightened awareness of nationalities- friendships of the people in propaganda, in Kalmyk children institutions, the trend of children's clothing increasingly Sovietized as was evident in orders of school clothing. For example, in 1932 the Bolushesko Children's Home spent a total of 505 rubles on "baseball shirts," longsleeve sweaters, and sports clothes, while it continued to order aprons and woolen material as prescribed in early Soviet published pedagogical manuals. ${ }^{187}$

In addition to ideas of purity and cleanliness as well as fashion, physical culture also played a role in portraying the ideal Soviet child's body. Bolshevik officials paid more attention to questions of physical culture and children's (and youths') bodies just

\footnotetext{
${ }^{184}$ U. E, Erdinev, K.N. Maksimov Kalmyki: Istoriko-Etnograficheskie ochkeri (Elista: Kalmytskoe Knizhnoe Izdatel'stvo, 2007), 315.

${ }^{185}$ Erdiniev and Maksimov, Kalmyki, 300. Also see Harvard Project, Schedule B-5, Case 15, p. 17, 20.

${ }^{186}$ Harvard Soviet Project, Schedule B-5, Case 15, p. 20.

${ }^{187}$ NARK, R- 95, o.1, d. 37, "Delo s avansovannii detdomov", p. 211-229.
} 
before the introduction of the First -Five Year Plan, where even Komsomol'skaia Pravda dedicated a special column to physical culture events on its daily editions in $1927 .{ }^{188}$ Physical culture campaigns became more prevalent in the 1930s, especially in propaganda journals that would boast that through sports and hard work, a child and youth could achieve a beautiful body. Propagandists gave tremendous credit to the state with its initiative in providing numerous sports centers throughout Moscow. A 1936 Pravda article reported on a Moscow physical culture parade that "showed the strength and beauty of our youth — the happiest youths of the world." ${ }^{189}$ The parade directors "invited children from all of the colonies," creating Pan-Soviet events and performances on Red Square - the heart of the empire-- while featuring special guests from Ukraine and Belarus to participate in exercises of physical culture.

Physical culture campaigns were part of a broader global movement that were also prevalent in Western democratic nations and Fascist countries, including Nazi Germany and eventually Franco Spain. Whereas in Soviet-Russia, the children and youths were at the center of physical culture campaigns, in Spain, the regime focused on women as center to physical culture campaigns looking for "an ideal body type and corporeal beauty." ${ }^{190}$ By comparing the various contemporary states with dictatorships, it is evident that all three used similar language and equated physical education to a form of spiritual perfection (whether Soviet in Russian case, religious in Spain or

\footnotetext{
${ }^{188}$ One example that includes discussions on the growth of the movement can be found in "Fizikultura na perelome, v poriadke obsuzhdeniia”, Komsomol'skaia Pravda, March 6, 1927.

189 “Parad pokazal silu i krasotu nashei molodezh” Komsomol’skaia Pravda, July 7, 1936.

${ }^{190}$ Aurora Morcillo, The Seduction of Modern Spain: The Female Body and the Francoist Body Politic (Lewisberg: Bucknell University Press, 2010), 184-188.
} 
nationalist in Germany). In addition, sports were an essential component in the physical culture projects throughout Europe. In the Soviet Union, children were engaged in popular sports such as volleyball and basketball, not only in Moscow, but as discussed in previous chapter, the same was true for Kalmykia. ${ }^{191}$ Physical culture was not relegated to perfecting the child's body through sports, but also through natural- based experiences such as spending time in nature hikes which were prevalent in rural areas. ${ }^{192}$ The same true for Kalmykia where schools, children's colonies, and homes organized kolkhoz work or nature work "to improve physical culture." ${ }^{193}$ As discussed in the previous chapter, Kalmyk children were engaged in recreational activities in the outdoor camps. An inspector in the Astrakhan region noted that "one of the main goals of winter camps was to "strengthen health with mass physical culture" by requiring children to spend at least $50 \%$ of their time outdoors. In the late 1930s Kalmykia saw its fair share of physical culture campaigns known as 'olympiads' that were held in the district and in the oblast. According to one Kalmyk man, the competitions entitled the best athlete to compete in the republic or oblast level, who then went on to the capital. In Kalmykia, he reported that the 1936 contests lasted for two weeks, and was a moment in which Kalmyks, who were forced to throw away traditional clothing, wore their national costumes and the Soviets "indulged in [their] old rights." ${ }^{194}$ Again, this statement reinforces the tension

\footnotetext{
${ }^{191}$ As Aurora Morcillo shows in her study, the same was true for Spanish girls and young women in Francoist Spain.

${ }^{192}$ See Catriona Kelly, Children's World, 485-6.

${ }^{193}$ NARK, f. R-25, o. 2, d. 188, "Spiski sotrudnikov v narodnoe obrazovanie shkol, kolonii, detdomov," p. 17.

${ }^{194}$ Harvard Project. Schedule B, Case 23, p. 9.
} 
between Soviet propaganda that romanticizes the cultural distinctions of the republics and the reality that children had to conform to wear Soviet-style clothes. Regarding the fashion during the olympiads, the same man added that, "only those who had buried their costumes could wear them." ${ }^{195}$ According to the interviewee the olympiads served the purpose of not only strengthening the health of the empire, as the propaganda would suggest, but to regain the trust of the population who had just endured collectivization and famine.

\section{HEALTH IS THE DISTORTION OF THE BYT- THE EVERYDAY HYGIENIC SPACE} AND PLACE

A crucial way in which Soviet pedagogues attempted to transform children's everyday lives through health was to ensure a safe, secure, and clean environment. In official ideology, children were to be self-sufficient and self-disciplined in regards to hygienic practices. It is clear in Soviet pediatric treatises that adults (i.e., Kindergarten directors, parents, doctors) held the ultimate responsibility in overseeing and protecting children's health and ensuring proper hygienic routines. For Soviet child specialists, "...the sanitary direction of work facilities should occupy especially the main place of the Kindergarten." ${ }^{\text {196 }}$ Health depended on the conditions of a child's environment from lighting to cleanliness and the compartmentalization of spaces for hygienic practices.

The primary factor in strengthening children's health was lighting, and sunlight, in particular. Children's bodily development, according to Soviet pediatrics, relied on exposure to sunlight. It was seen as so crucial that they emphasized the Italian proverb

\footnotetext{
${ }^{195}$ Harvard Project, Schedule B, Case 23, p. 9, 17.

${ }^{196}$ Morozova et al., Sovremennyi Detskii Sad, 63.
} 
"where the sun cannot be seen, the doctor will always be seen." ${ }^{197}$ In order to ensure proper exposure to sunlight, pediatricians gave school directors further instructions to make sure that there were no dark corners and that there was ample space for the sun to shine through.

Inspectors' reports and pedagogical manuals, such as Detskii Sad (The

Kindergarten), provided detailed instructions for child institution maintenance that would ensure optimum health and physical development. All agree that the environment had to be inviting, "carefully cleaned", exposing bedding, mattresses, sheets and pillows to the air and sun, as well as washing and polishing floors, freeing them from dust. ${ }^{198}$ Instructors placed urgency on these directions, claiming that failure to follow them would result in direct bodily harm to the child, or dirty legs with rashes, or difficulty breathing from dust.

Furthermore, pediatricians advised directors to create an environment conducive and appealing for children themselves to practice hygienic routines. They warned instructors to avoid having children clean over the sink in "extremely uncomfortable and awkward positions." They also warned against using tap water that tended to be extremely cold, and emphasized that a "child cannot learn like this." ${ }^{199}$ As a way to remedy this problem, the manual informs that it is more effective to have low table with

\footnotetext{
${ }^{197}$ Morozova et al., Sovremennyi Detskii Sad, 65.

${ }^{198}$ Morozova et al, , Sovremennyi Detskii Sad, 68.

${ }^{199}$ Morozova et al., Sovremennyi Detskii Sad, 65.
} 
basins and jugs. ${ }^{200}$ To further facilitate hygienic routines and maintain cleanliness on their bodies, instructors were to provide each child with their own towel.

The care of children's health and hygiene was not only practiced during the academic session in schools, but year- round, including summer camps, which the People's Commissar of Health (Nakomzdrav) M. Semashko referred to as "Centers of hygiene, care and necessaries. ${ }^{" 201}$ In his statement, Semashko lamented the conditions of child health which should be the "first order of demands." $202 \mathrm{He}$ criticized the "unhealthy living conditions" at school, in and around the home, and the failure of counselors to remedy the situation. Furthermore, Semashko emphasized that camps should primarily focus on engaging children in physical training "which were essential for the development of kids' (rebiat) hygiene"203

As evident from propaganda and news reports, the protection of children's bodies and hygiene was a central preoccupation in all parts of the Soviet Union. In the early 1920s, Kalmyk inspectors made the same claims regarding children's health as their Moscow counterparts such as maintain proper "conditions of life" in order to avoid "danger to their [children's] health." ${ }^{204}$ Kalmyk inspectors took precautionary measures in protecting children's bodies, mimicking State ideals by manipulating the environment, primarily through searches and surveillance: "Monitor for purity and cleanliness in the

\footnotetext{
${ }^{200}$ Morozova et al., Sovremennyi Detskii Sad, 65.

${ }^{201}$ M. Semashko, "My Ne Zabotimsia o Zdorovie detei” Komsomol'skaia Pravda, July 5, 1928.

${ }^{202}$ Semashko, "Ne Zabotimsia.”

${ }^{203}$ Semashko, Ne Zabotimsia."

${ }^{204}$ NARK, f. R- 25, o. 1, d. 226, "Doklady Inspektorov,” p. 93.
} 
bedrooms, do not let them store food. ${ }^{, 205}$ Also, inspectors warned that children should never be left unattended and make sure they are bathing where appropriate, checking children's water and light. ${ }^{206}$ In a local meeting held in May 1923, the Commission for Homeless and Sick Children decided to set up donation centers in the city to collect for the homes and held lectures for children's hygiene and address sanitary defects in order to improve the conditions of children's institutions. ${ }^{207}$ In addition, T. Kalantarov instructed inspectors to conduct sanitation surveys and inspections in homes and ensure that directors implemented games to ensure children's mobility.

Other careful steps that inspectors took in child bodily protection included quarantining sick children from the healthy ones by asking child institution directors to take active searches and precautions. In keeping with the principles of rational strategic spaces and places as discussed in the previous chapter, Kalmyk officials mandated to plan out places to improve children's health and asked school or children's homes directors to separate bathrooms from laundries and segregating them from the kitchen. ${ }^{208}$ Regional inspectors urged children's homes directors to ensure light and dryness in the rooms, and to segregate rooms according to activity. ${ }^{209}$ According to the inspector's report, Children's Home No. 1 was also successful in maintaining laundry and washing mattresses and pillows to "decent enough" standards. The school officials also ordered

\footnotetext{
${ }^{205}$ NARK, f. R-25, o.1, d. 226, “Doklady Inspekotorov”, 84.

${ }^{206}$ NARK, f. R-25, o. 1, d. 114, "KONO Sots vospitanie”, p. 100.

${ }^{207}$ NARK, f. R-24, o. 1, d. 115 "Zasedanni Tsentr Kommissii po provedenniiu nedeli besprizornogo i bol'nogo rebenka pri TsIK Kalmoblast", "Protokol”, 1923.

${ }^{208}$ NARK, f. R-25, o.1, d. 116, "Doklady Inspekotorov", 85.

${ }^{209}$ NARK , R-25 o. 1, d. 116 , "Dokaldy inspektorov", 85.
} 
new bedding and mattresses and towels for each of the children. In at least this one Kalmyk children's institution, these satisfactory marks reveal how directors were able to keep up with state-mandated and progressive practices of hygiene and care of children's bodies.

Adults played a central role in ensuring the success of children's health and instill everyday hygienic practices. While in all cases teachers and other individuals were involved in transforming children's everyday lives, it is in hygiene where they hold an even more involved position. In particular, doctors were central to the Soviet children hygienic projects and should be stationed in institutions, such as Kindergartens, "to help cure children and help with physical and psychological development." ${ }^{210}$ Employing doctors and specialists revealed a central preoccupation with the Soviet project of modernizing the state through rationally-planned hygienic campaigns with the use of professionals and the sciences. In keeping with this idea, Soviet pediatricians and pedagogues emphasized the need for doctors who were 'familiar with children's bodies and "to ensure a weight and measurement standard for healthy children."211

While doctors and inspectors in Kalmykia played a central role in maintaining hygienic practices in children's institutions, parents are rarely mentioned in the sources (this is logical in children's homes, but even in Kalmyk schools and kindergartens officials did not ask for parents' support). In cases that they are referred to, parents are asked to be less involved in taking care of their children. For example, the 1929

\footnotetext{
${ }^{210}$ Morozova et al, , Sovremennyi Detskii Sad, 80.

211 TsAGM, f. R -528, o. 1, d. 29 "Stenogramma konferentsii po shkolnomu pitanio sozvannoi moskgorpitam MosGorONO i Mosgordravom (skholnyi sektor)”, p. 13.
} 
Komsomol'skaia Pravda article discussed how Komsomol representatives warned Kalmyk women against breastfeeding children since it lead to "common diseases," and taught women to boil the milk instead. ${ }^{212}$ In Moscow, however, officials and child specialists held ambivalent attitudes towards parental involvement in children's hygiene. In fact, the hygiene section in Morozova's instruction manual for kindergartens begins with a disapproval of Russian cleaning and hygienic practices: "Our Russian culture does not have consciousness of (...)sanitary standards" ${ }^{\prime 213}$ On the one hand, Moscow inspectors chastised parents for 'continued backwardness' and placed blame on them for their child's health and everyday living conditions. On the other, they believed parents' involvement in children's hygienic habits as paramount to the success of the health campaigns. "Comrade Parents," they argued, "you need to focus more on your child's health and physical culture" and "raise your children in urgent matter, the health is dependent on the distortion of the byt." 214

THE FIGHT FOR CULTURAL UPBRINGING: LOCAL STRUGGLES IN MAINTAINING STATE IDEALS OF HEALTH

“The Fight for Cultural Upbringing (Bor'ba za kul'turnogo vospitaniia) demands absolute full sanitation hygienic minimum in each children's institution."215

\footnotetext{
212 “Tam Gde Moloko l'estia rekoi,” Komsomol’skaia Pravda, June 26,1929.

${ }^{213}$ Morozova et al, , Sovremennyi Detskii Sad, 62.

${ }^{214}$ TsAGM, f. R- 528, o. 1, d.70, "Doklad Tov. Zolotukhina, zadachi shkolnyi i pionerskogo otriada v novom uchebnom godu ot 2 sentiabra 1933," p. 6-7.

${ }^{215}$ TsAGM, f. R528, o. 1, d. 416 "Stenogramma konferentsii rabotnikov detskikh domov, o predkakh, trudovii obuchennie i grammotnosti- vospitannikov v detskikh domakh," 13.
} 
Despite the ideals, propaganda, and the portrayals of the hygienic campaigns as successful on the ground level, pedagogues, directors and inspectors fought to maintain or reach state standards. In both Kalmykia and Moscow, health officials and children's institutional directors held achievements and failures in producing quality health care for children. In Kalmykia, as discussed in the previous section, inspectors as early as 1921 reported examples of children's homes that passed sanitary inspections. In the Kalmyk Bazaar region, only one school met satisfactory levels of cleanliness and healthy in children's bodies. The report claimed that the children's physical bodies were "free from parasites... as well as their heads, hair and clothes." ${ }^{216}$ The inspector attributed the school's successes because of its ability to meet basic material needs such as adequate children's clothing, "beli," shirts, stockings, coats and jackets to protect them from the warmth and even regularly washing bed sheets in the separate laundry room and children's bathroom.

However, not all children's institutions in Kalmykia were as successful in reaching hygienic and health standards for children. The most severe case reported was children's home "The Third International," which consistently scored below average marks with its "deplorable conditions", and left children around "hungry and sick." ${ }^{217}$ In addition to the dirty conditions, the institution did not provide warm clothes and sheets which failed to protect children's bodies from the cold. Children's Homes No. 2 and No. 3 also fell into the same category, with a "lack of ventilation" (as prescribed in state advice manuals), "very dirty conditions," and insufficient bed sheets, so "children were

\footnotetext{
${ }^{216}$ NARK, f. R-25, o. 1. d. 116, "Dokaldy inspektorov", p. 2.

${ }^{217}$ NARK, f. R-25, o. 1, d. 116, “Dokaldy Inspektorov”, p. 3.
} 
left at night without them." ${ }^{218}$ The inspector added that there was a lack of quality underwear and medicine available in the home. Another disturbing observation was that the home director neglected to quarantine sick children, thus integrating sick bodies with the healthy ones. A health report published by the Department of Health Kalmyk Oblast deemed Children's Home No. 1 as "extremely unsatisfactory" noting several violations including children's clothing being "perpetually dirty." Another inspection in Children's Home No. 1 blamed the staff for "ignoring the demands of school officials to give children free time in clean air" and allowing "children going around [the house] wet with dirty shoes," thus failing to protect children's bodies. ${ }^{219}$ One school director who was also Kalmyk noted that there were not enough shoes for children "since the economy was supposed to produce them. ${ }^{, 220}$ While the sources do not indicate the motives for why inspectors openly criticized the deplorable conditions of children's homes, one possible reason (at least in the early 1920s) is that children's institutions lacked significant funding from Narkompros for proper maintenance. ${ }^{221}$ In the 1930s, when criticisms become harsher and more prevalent, it tends to follow the trends of the Stalinist Culture of Criticism. ${ }^{222}$

Lack of cleanliness and mismanagement were only part of the problems that lead to the failure to provide proper care for children. Shortage of medicine in children's

\footnotetext{
${ }^{218}$ NARK, f. R-25, o. 1 d. 116, “Akt no 4,”, p. 7.

${ }^{219}$ NARK, f. R-25, o. 1, d. 262, "Spiski vospitannikov detdoma", p.1.

${ }^{220}$ Harvard Project, Schedule B, Case 15, p. 11.

${ }^{221}$ The previous chapter notes the Kalmyk school Inspector Vassili Porokh's critiques of Narkompros for neglecting Kalmyk schools.

${ }^{222}$ This point is further explored in Chapter 5.
} 
institutions exacerbated children's health problems in the region. One of the major causes for lack of medicine was the missing of state-medicinal funds in which regional doctors desperately sought assistance from the community in forms of gifts or donations. ${ }^{223}$ The combination of dirty environments, lack of clothing, sheets, and medicine amplified the conditions for diseases to break out in children's homes. Regional school sanitation doctor Kalantarov was concerned of the lack of cleanliness and insufficient staff in the homes. In his health report released in 1922, Kalantarov observed a number of children with infected eyes which became a severe threat (ugroza) to the entire institution. He called for the need to secure medicine and "take measure quickly to improve [children's] health and eyes." ${ }^{224}$ Kalantarov noted the seriousness of the health threat and warned that that without medicine would result in the "serious threat of cholera and scurvy" which was prevalent in, during, and immediately following the Civil War in Kalmykia.

Moscow children's institutions confronted their own struggles in sanitary maintenance and hygienic practices. Like their Kalmyk counterparts, inspectors and health officials observed well-maintained and neglected homes throughout the city. Moscow children's homes in late 1920s spent an average of 3,300 rubles for the academic year for the following care materials and services for children's homes including: clothing detergent, bathroom soap, first-aid kits, haircuts, tooth powder, toothbrushes, and shoe polish. ${ }^{225}$ As was made clear in reports of children's homes in Kalmykia, the availability of material health and hygiene goods was intrinsic to

\footnotetext{
${ }^{223}$ NARK, f. R-25, o. 1, d. 116, “Narodnyi Komissariat dlia Otdela Obrazovanie, 1922,” p. 69.

${ }^{224}$ NARK, f. R-25, o. 1, d. 116 “Doklady inspektorov: Akt no 12- Dosmotra Kalm Dome, 1922,” p. 11.

${ }^{225}$ TsAOM, f. 2614, o. 1, d. 22, "Raskhodyi po ukhodu, 1922 -30", p. 10.
} 
maintaining children's health. Also, children's homes that had proper health facilities for children were noted in their achievements in not only strengthening children's health, but also their character. One example can be found in School No. 37 in the Leningrad raion (district), where, according to the inspector, the showers that were installed not only improved children's health habits, but also their overall discipline. ${ }^{226}$

However, not all Moscow children's institutions succeeded in maintaining satisfactory sanitary conditions. For example, one report cited the city school in Dzerzhinsky raion as "appalling” and "terrifyingly dirty” failing to practice cleaning habits. ${ }^{227}$ Another inspector recorded how School no. 5 in Stalin raion (district) was "always dirty," and questioned school officials "why not have children participate in at least cleaning the dishes?"228 In her study of the origins of Narkompros and the introduction of experimental schools, Sheila Fitzpatrick notes how the Viatskia Oblast in the early 1920s reveals a similar trend of poor sanitary and hygienic practices in children's institutions. One observer noted the conditions in an experimental children's colony where he noted that "shirts are dirty, insects are nesting on the body, so washing of shirts is on the agenda." 229 Yet, not all Soviet officials agreed that on the efficiency of children washing and maintaining their environs as part of the Soviet child and collective effort. Fitzpatrick recounts Lebdev Polyansky's critique of the labor school system in its failure to produce the desired outcome: "they made the little children wash their own

\footnotetext{
${ }^{226}$ TsAGM, f. R-528, o.1, d. 29, "Stenogramma konferentsii po skholnomu pitanniiu, 1933," p.15.

${ }^{227}$ TSAGM, f. R-528, o.1, d.29, p. 15.

${ }^{228}$ TSAGM, f. R-528, o.1, d.29, p. 96.

${ }^{229}$ Found in Sheila Fitzpatrick, The Commissariat of Enlightenment: Soviet Organization of Education and the Arts Under Lunacharsky, October 1917-1921 (Cambridge: Cambridge University Press, 1970), 51.
} 
linen, clean rooms, carry buckets of soap through the frost... and naturally the children were not really helping or doing 'productive labor' but getting themselves dirty through being in unsanitary conditions. ${ }^{230}$

In relation to child discipline in health and hygiene practices, other incidents of neglect were noticed in the Moscow region even as late as the 1930s. For example, in Children's Home No. 8, inspectors complained that children were not brushing their teeth and walked around the premises with dirty bodies. ${ }^{231}$ In another case, inspectors observed a school in the Oktiabr district where they asked teachers to watch children and note whether or not they wash their hands during the 15 minute break. The inspectors noted that this practice "did not take place." A similar incident recorded in the Proletarian district noted a doctor's response that children fail to wash their hands because they do "not have the cultural knowledge to do so" (oni eshche ne kul'turnii). ${ }^{232}$ Again, this point of children's hygiene and health, even in the ground level was linked to notions of culture in which as noted in state manuals and by regional inspectors. With these consistent failures in meeting state sanitation standards, especially as a result of material shortage, even Moscow schools had yet to reach had to continue to fight towards transforming children to their Soviet model as did their Kalmyk or non-Russian counterparts.

Such examples of failures in maintaining sanitary conditions in children's institutions have been reported in other locations throughout the Soviet Union.

\footnotetext{
${ }^{230}$ Fitzpatrick, The Commissariat of Enlightenment, 54.

${ }^{231}$ TsAGM, f. R-528, o.1, d.29, p. 13.

${ }^{232}$ TSAGM, f. R-528, o.1, d.29, p.10.
} 
Contemporary British-American journalist, Walter Duranty, noted his observations of his visit to a children's home in Samara, located in the Volga region (southeastern part of European Russia). According to Duranty, the "children's homes" were equivalent to a "pound for homeless dogs." ${ }^{233}$ He noted the attempt made at segregating the sick and healthy children, as part of Soviet regulation. Despite the minimal efforts made by the home directors, Duranty reported that children were "past hunger" and observed children's fingers as being no larger than "matches." He continued to describe the deplorable conditions of the interior as "dreadful...the most noxious atmosphere I have ever known. ${ }^{234}$ When he confronted the two women care-givers, they responded that they had no means to provide the children with soap or medicine: "There were 400 children....and a hundred more brought in daily and about the same number died; there was nothing they could do."235

\section{CONCLUSION}

As evident in propaganda and actual practices, children's bodies became objects of state-driven campaigns to improve health of nation and empire. Regardless of location, or ethnic background, the link to Soviet citizenship and proper childhood was comprised of a child's dress, level of purity and cleanliness (inward and out), selfdiscipline, and health. Practices of medicine and hygiene were more than scientificpragmatic factors that would thrust the Soviet Union's drive towards a new modern era. They were also regarded as Soviet-cultural features that without practices of health and

\footnotetext{
${ }^{233}$ Walter Duranty, I Write as I Please (New York: Simon and Schuster, 1935), 130-131.

${ }^{234}$ Duranty, I Write, 131.

${ }^{235}$ Duranty, I Write, 131.
} 
hygiene, children --whether ethnically Russian or not-- would still be considered backwards, uncultured and therefore, un-Soviet.

Both cases of Kalmykia and Moscow reveal how officials' attempts in to transform children's everyday lives $(b y t)$ in terms of health regimens, dress and care were met with similar challenges and outcomes. While officials intended to carry out their duties in propagating Soviet mandates on proper routines, they usually encountered shortages and incompetent caregivers. The shortages and untrained professionals created an unhygienic atmosphere in terms of cleanliness rather than the state- idealized one of purity and properness. Thus, children in both the periphery and metropole, while acquiring lessons on dress and cleanliness, failed in a sense to experience the state ideals of Soviet purity. In fact, Kalmyk pedagogues and persons recounting their childhoods in early Soviet Kalmykia blamed the Soviets for the demise of Kalmyk health and constitution. One in particular acknowledged that although there was a growth of medical aid and services starting in 1917, "the Kalmyks were not dying out [in the tsarist era]." 236 He attributed this to the old Kalmyk lifestyle of an outdoor life and intramarriage practices, which for him was the cause of the rise of tuberculosis in the region.

The Soviet preoccupation with children's bodies did not stop at hygienic routines and dress. Soviet officials turned their attention towards food, children's nutrition and eating habits, as extended practices of state-driven Sovietizing childhood campaigns and the road to Cultural Enlightenment.

${ }^{236}$ Harvard Project, Schedule B-5, Case 68, page 6. 


\section{CHAPTER IV: SOCIALIZATION IN THE LUNCHROOM: CHILDREN'S FOOD}

\section{CONSUMPTION IN EARLY SOVIET RUSSIA}

Nash gerb'-Molot i serp

Molota- bakh! Bakh!

Ves'pool—v serpakh

\section{(...) Budet khleb}

Po rzhi

Vzhi! Vzhi!

Serpy-po rzhi!

Padai kolos!

Budet khleb...
Our seal is the Hammer and Sickle

Hammer- bang! Bang!

The whole ground in the sickle

There will be bread

In the rye

Swoosh! Swoosh!

The sickles in the rye

Fall the ears (of rye)

There will be bread... ${ }^{237}$

Figure 6: Illustration of Men and Women Working:

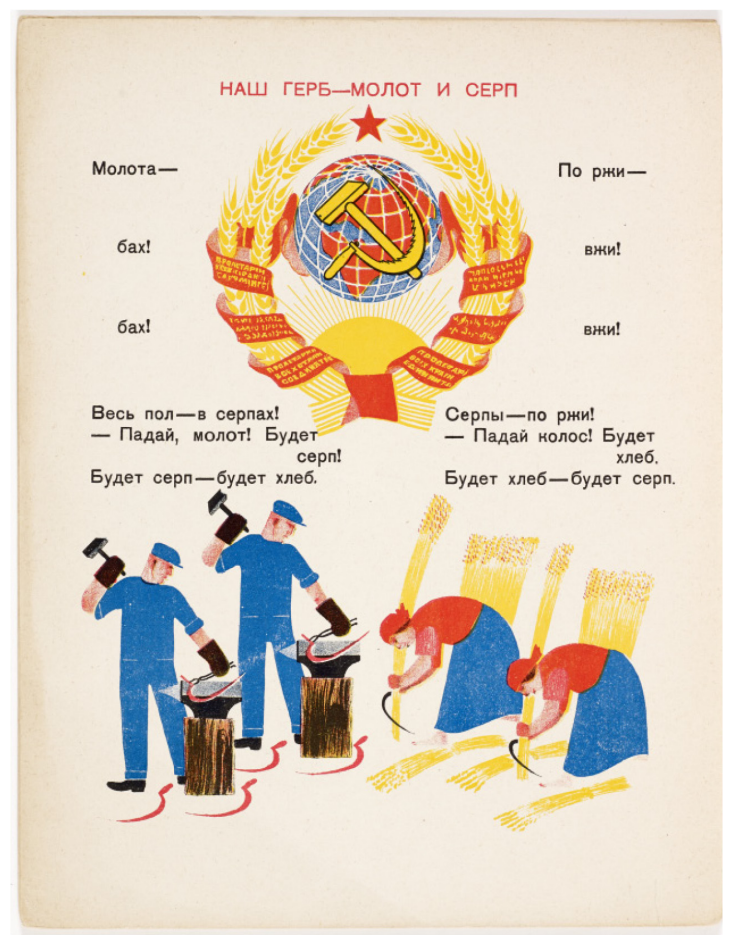

${ }^{237}$ Natan Vengrov, Oktiabr'skie Pesenski, (Gorod: Gosudartsvennoe Izdatel'stvo, 1927). Published with the permission of The Wolfsonian-Florida International University (Miami, Florida). 
The above poem is one of many included in Natan Vengrov's children's book Oktiabr'skie Pesenki (October Songs). Published in 1927, Oktiarbr'skie Pesenki taught children what constituted a proper Soviet man or woman. It focused on quintessential characteristics such as love of work and collectivity. Vengrov's poem, printed on a colorful page bordered by crude primary color, features illustrations of men in blue uniforms hammering on the left with women wearing traditional peasant clothing (red and blue skirts and head scarves), harvesting rye in the gold fields, holding their sickles. At the very top of the page is a large illustration of the hammer and sickle seal. The imagery of work on the fields and harvesting of rye by men and women accompanied by the song reveals a central concern for Soviet officials: that food would be one of the many factors to modernize and propel the Soviet project. In order to "modernize" the Soviet Union through food production, the Bolsheviks initiated technological projects to create more efficient techniques in food production and distribution.

The notion of food served in two key ways as an avenue for Soviet propaganda aimed at children: First, it provided a way to distinguish the regime from the "repressive" past by promising food abundance to its population that had suffered under tsarist rule. Secondly, the notion of food created an ideology combining the everyday eating experience with collectivity and civility with the State as the great provider throughout the Soviet Union. As depicted in the above poem and description, the efforts of the peoples in collecting the food, along with consumption, reveal that food not only symbolized the Soviet promise of needs being met, but also worked as a touchstone of Soviet unity of how food was intended to be a unifier, or a collective experience that would unite disparate peoples. Breaking from the past and initiating new techniques of 
food production that resembled its Western counterparts were part and parcel to the Soviet modernizing projects. By engaging these methods, the Bolsheviks used ideas of food in both cuisine and eating practices as a way to create an everyday, common "Soviet" experience among various ethnic minority children. As evidenced in propaganda journals, children's instruction manuals and reports, in continuing to care for children's bodies, the Soviet child care specialists simultaneously worked on building proper hygienic habits as well as nutrition and eating practices as part of the creation of a common childhood which served as building blocks to Soviet imperial processes among children. Furthermore, the Soviet childcare specialists including Morozova et. al., attempted in modernizing children's eating habits by implementing what they called 'rational feeding' guidelines.

The notion of food, in all aspects-- its consumption, availability and accessibility- played a significant part in the Soviet campaigns to rescue children. Even as early as 1918 Soviet officials organized and created institutions such as children's homes, kindergartens, and schools that would play a role in providing food for children. The crisis of homeless children deepened in the early 1920s, after the Civil War, when the Soviet Union was left with millions of homeless children. ${ }^{238}$ Yet, the projects of child feeding were not limited to the larger cities, nor to European Russia, but also extended to other regions within the empire, including, what would become the Kalmyk ASSR. The Kalmyk peoples' prerevolutionary eating habits followed those of Central Asian- steppe patterns, in both the types of food eaten and the everyday eating practices and rituals. For Soviet officials, ensuring children were given proper nutrition was a significant

${ }^{238}$ Ann Gorsuch, Youth in Revolutionary Russia: Enthusiasts, Bohemians, Delinquents (Bloomington: Indiana University Press, 2000). 
preoccupation in this region as they ordered, purchased, and distributed foodstuffs to children on a daily basis over the course of the early revolutionary period (and beyond).

Yet, while Soviet officials designed propaganda, diet plans, and promises to provide food for children throughout the Soviet Union, they were faced with historical challenges. Just as in the cases of space and hygiene, the Soviet plans to modernize the population - through transforming their everyday lives by incorporating more RussianSoviet educational, social and in this case eating practices-- were met with political, social, and economic consequences when local officials attempted to implement these practices. While, again, most scholars and even Soviet propaganda portrayed ethnic Russians as advanced in their technology, more civilized in eating habits, and in food acquisitions, a comparative examination between the Republic of Kalmykia (predominantly of Central Asian culture) and Moscow (representing Russian culture) children's institutions' eating practices, shows how children's experiences in both ethnically polarized locations faced more similar challenges despite ethnic differences.

State discourses surrounding food played a role in the Bolsheviks' projects to create a common Soviet identity among children of different backgrounds throughout the empire. Since food was depicted as a marker of state abundance, health and a promise to children, it became an imperial tool that would reinforce the Bolsheviks' legitimacy.

The Bolsheviks focused on local cuisine and food consumption habits throughout the Soviet Union, and allowed the populations of different regions a degree of political and cultural autonomy under Soviet rule, as was promoted in the official discourse and the early Revolutionary concept of 'national in form- socialist in content,' which was the slogan that supported ethnic autonomy as promised in the Soviet nationalities campaigns 
of the 1920s. Food practices reflected the intersection of government intervention in the "daily lives of people in constituent republics." ${ }^{, 239}$ As seen in other Soviet republics, the Soviet intervention in people's everyday lives throughout the empire reveals how over time and in small increments food practices, in forms of food preparation and eating habits became "Sovietized"-in terms of instilling values of work collectivity in sharing the tasks of food preparation and the experience of comraderie while eating with their peers. ${ }^{240}$ Just as the intervention in children's everyday lives in their schools and bodies intended to shed their pre-Soviet bourgeois tendencies, changes in foodstuffs and eating practices served to create the New Soviet Citizen. Some of the main changes that took place were mostly in food products themselves with the introduction of a standardized Soviet diet. After the Russian Revolution, the republics in the RSFSR and Soviet Union saw an increase in the availability of foods such as "soviet-style sausages." 241 Traditionally Russian dishes, such as pelmeni (dumplings) and borscht, were no longer seen as 'foreign foods,' and thus created a fusion between Russian and other ethnic cuisines.

\footnotetext{
${ }^{239}$ Joyce Toomre, "Food and Nationality in Soviet Armenia," in Food in Russian History and Culture eds. Musya Glants and Joyce Toomre (Bloomington: Indiana University Press, 2009), 198. The essays in the collection have looked at the various factors such as food "production, preparation, consumption, attitudes towards food and ...symbolism"-all within the context of historical periodization, politics, religion, and social class. According to Glants and Toomre these combined elements create a "complex of attitudes and tradition" they refer to as "Russian foodways." The concept of Russian foodways, which this chapter adopts, is a useful tool, because it is not a fixed notion, but changes according to historical transformations, including, modernization projects such as industrialization and urbanization. Melissa L. Caldwell, ed. Food and Everyday Life in the Post-Socialist World (Bloomington: Indiana University Press, 2009). Also see The Domostroi: Rules for Russian households in the Time of Ivan the Terrible, ed. and trans. Carolyn Johnston Pouncy (Ithaca: Cornell University Press, 1994). and Classic Russian Cooking: Elena Molokhovets' A Gift to Young Housewives, trans. Joyce Toomre, (1998).

${ }^{240}$ Toomre, "Food Nationality in Soviet Armenia," 198.

${ }^{241}$ Toomre, "Food Nationality in Soviet Armenia," 209.
} 
While the topic of food may seem like an obvious choice for the study of the everyday, scholars' approaches to food in the context of the Soviet Union have been political and social, only recently have focused more on culture, by studying more on individuals' everyday lives and practices, through microhistory. Scholars focusing on food in Tsarist Russia focus on the politicized nature of Russian cuisine by looking at how food played a role in the debates between the state and intellectual elites such as the Westernizers and Slavophiles. While food studies focus on the everyday practice of eating in the Soviet Union, they also show the role that food played in larger social and political changes, especially towards consumer practices that followed larger political-economic ideological trends. In the 1930s, during Stalin's First-Five-Year Plan, Soviet officials produced propaganda and placed inflated expectations of mass production in food plants in order to fulfill the State's initial promises of food abundance. This drive to mass produce foodstuffs and consumer goods in the 1930s was partly to introduce a new aspect to the New Soviet Man as consumer, which is in stark contrast to the 1920s when the state only recognized its population as workers. The consumer campaigns were part and parcel with Stalin's Life Becoming more Joyous campaign, which would extend to the Happy Childhood campaign for children. Both campaigns, with their flamboyant parades and celebration of State progress masked failed realities for the State meeting its population's basic needs and the political Terrors. ${ }^{242}$

\footnotetext{
${ }^{242}$ Allison K. Smith, Recipes for Russia: Food and Nation Under the Tsars (DeKalb: Northern Illinois University Press, 2008); Alison K. Smith, "National Cuisine and Nationalist Politics" in Kritika: Explorations in Russian and Eurasian History 10, 2 (2009): 239-260.; Catriona Kelly, Refining Russia: Advice Literature, Polite Culture, and Gender from Catherine to Yeltsin (Oxford: Oxford University Press, 2001). Amy E. Randall, The Soviet Dream World of Retail Trade and Consumption in the 1930s (New York: Palgrave, Macmillan, 2008). Karen Petrone, Life Has Become More Joyous, Comrades: Celebrations in the Time of Stalin (Bloomington: Indiana University Press, 2000).
} 
Not only were the everyday habits of food consumption controlled and changed according to historical realities, but the types of foods consumed also underwent scrutiny by the state. Soviet officials gave ideological meaning to foodstuffs. Bolsheviks attacked foods that had religious and 'bourgeois' associations by marking them as politically suspicious (i.e., Matsa, unleavened bread, which is a traditional Jewish food staple). ${ }^{243}$ Representations of food, however, were not limited to negative (banning), anti-Soviet character but could also represent positive, utopian ideals. For example, as this chapter discusses below, the majority of the food items consumed in Kalmyk schools were almost identical to those found or suggested in propaganda and instruction manuals from the state publishing houses as part of the State's investment in the everyday practices of children's food consumption becoming more uniform such as the consumption of certain bread and grains as well as the eating practices and uniformity of eating utensils.

As early as 1920, with the establishment of cafeterias, canteens, soup kitchens and collective dining the Bolsheviks intended these new places to encourage collective practices that facilitated in the creation of the new soviet man. Thus, not only everyday habits and routine, but space played an important role in the shared experience of food consumption, just as it had for children's bodies, education and leisure. The eating of the same foods (with some national variations), in a similar setting — the stolovaia — the routine of time, place, practice all served to shape both adults and children into Soviet citizens, including those who were non-ethnically Russian. The stolovaia or canteenwas crucial to the Soviet experience of food consumption and became an iconic location for a proper Soviet childhood. Thus, the concept of eating, the everyday, the repetitive

${ }^{243}$ Glants and Toomre, "Introduction”, xix. 
nature of it, over time - in increments --children and especially national minority children were able to adopt what were deemed as Soviet mannerisms, in which Russian customs prevailed, and acquire taste for what was considered appropriate Soviet cuisine and civility. $^{244}$

The Bolsheviks implemented their ideologies and instructions of food consumption on the local level. The routine- everyday practices of children's food consumption based on archival records from Kalmykia and Moscow reveal an earnest effort to provide food for children for health reasons and to reinforce another aspect of Soviet cultural norms within the context of eating.

\section{CONSTRUCTING THE STOLOVAIA}

During the initial stages of the Revolution, Soviet officials transformed the ways in which individuals would practice eating habits as part of the project to create the New Soviet Man or Woman. One of the primary ways this change took place was in the environment or the creation of a place to eat daily meals. Being more than just a place to consume food, Soviet planners, children's books authors, and child-care specialists agreed that the stolovaia would represent a common place where workers (and children) gathered, stood in line to acquire their foods, sit in groups and share the new, collective way of eating. For the Bolsheviks, the stolovaia represented a more modern place to eat

\footnotetext{
${ }^{244}$ Mauricio Borrero, "Communal Dining and State Cafeterias in Moscow and Petrograd, 1917-1921," in Food in Russian History and Culture, eds. Musya Glants and Joyce Toomre (Bloomington: Indiana University Press, 1997), 163. As of now, there is still no substantial scholarship on children and the relationship of food within the Soviet context. Scholars, including, Catriona Kelly and Lisa Kirschenbaum briefly address food in their respective studies, but only within the context of the state's intents and hindrances in providing for children. Catriona Kelly, Children's World: Growing Up In Russia, 1890-1991 (New Haven: Yale University Press, 2007); Lisa Kirschenbaum, Small Comrades: Revolutionizing Childhood in Soviet Russia, 1917-1932 (New York: RoutledgeFalmer, 2001).
} 
and a space to socialize and represented a break from the old, individualist, bourgeois traditions of dining at home with the family.

These revolutionary spaces and places of food consumption took precedence in children's institutions as they did in factories and workshops. One of the most influential architects of the Imperial Russian and Soviet Kindergartens, Elizaveta Tikheeva, devised rational and careful plans for establishing the proper eating space for young children, as early as 1919-20. ${ }^{245}$ According E. I. Tikheeva and her colleague Ya. M. Morozova, everyday eating habits and proper nutrition were crucial factors in children's upbringing and fostered socialization skills. Tikheeva and Morozova included instructions of how children's institutions should properly organize the stolovaia (cafeteria). They extensively listed what the appropriate types of furniture and eating utensils for children. In doing so, they emphasized that space was an important factor in the eating experience of socialist upbringing. They also understood that children's institutions would become the surrogate parents of children, especially of the new population of women workers, who would have little time to spend with their children "Children spend no less than 6 hours in Kindergartens - at least from 10 in the morning until 4 in the afternoon. In most cases, mothers are forced to go to work, and can only spend time with their own children sometimes between 7-8 in the morning. From 8-9 in the morning until 4 in the afternoon, children should be fed three times a day." 246

\footnotetext{
${ }^{245}$ Elena Shulgina, "Nasledie E. I. Tikheevoi kak tselostnaia pedagogicheskaia sistema" (PhD diss., Moskovskyi Gumanitarnyi Universitet, 2007).

${ }^{246}$ M. Ya. Morozova, E. I. Tikheeva and L. I. Chulitskaia, Sovremennyi Detskii Sad, Ego Znachenie i Oborudovanie (St. Petersburg: 1920), 74. Another central component to kitchens in Kindergartens was the iconic Russian samovar that allowed access to hot water. The Samovar, traditionally Russian, would be an essential feature in children's institutions across the Soviet Union, creation of another symbol that although culturally Russian, would eventually become standard and thus, Soviet.
} 
Children's collective habits in regards to food were not solely relegated to the stolovaia. According to Tikheeva and Morozova, the ideal Kindergarten would include a separate kitchen so that the children could learn new skills and feel included in the meal preparation process, as the preparation of food was an important factor in the overall food consumption experience and civilizing process. Tikheeva and Morozova's manual reflected these ideas by outlining or suggesting ways children should be included in kitchen duties. They advised that kitchen furniture should allow children to be able to reach cupboards and participate in storing groceries. Also, the ideal kitchen would be equipped with smaller tables so that the children would be able to participate in the food preparation process with ease. By including child-sized furniture in kitchens, pedagogues created a new space for children that reinforced their role and significance in the new socialist-building project.

While the kitchen fostered collective behavior in active work, the stolovaia was a place where children engaged in the civility process through eating and socializing with their peers. According to the instruction manual, the ideal stolovaia included child-sized tables and chairs that would seat 10 children, and made dining more comfortable. ${ }^{247}$ The process of civility and Soviet manners also included children's knowledge of properly using eating utensils. By providing children with knives, forks, spoons and mugs, pedagogues advised that through everyday practice and usage, children would acquire table etiquette. ${ }^{248}$ Thus, the places of the Kindergarten kitchen and stolovaia

\footnotetext{
${ }^{247}$ Morozova et al., Sovremennyi Detski Sad, 75. The manual specified that adults were to have their own, separate dining tables.

${ }^{248}$ Morozova et al., Sovremennyi Detski Sad, 110.
} 
simultaneously worked as common spaces of the Soviet childhood experience, where children could participate, prepare food, consume and share with their peers.

Kindergarten stolovye (and kitchens) played more roles in children's development than just places of food preparation and consumption. They were essential for children to receive proper nutrition and care for their growing bodies. Yet, the purpose of proper nutrition and the types of food children ate was not limited to their physical well-being, but psychological as well. In order for children to be successful in learning and growing, the manual's authors stressed on the importance of feeding and placed the responsibility of children's nutrition on Kindergarten directors. As the table below shows, the choice of foods in children's menus comprised of traditional Russian fare. However, the authors' choices of food types and their quantities reflect on their understanding of children and children's bodies as distinct from adults', which is crucial to the understanding of Soviet conception of children and childhood that was novel vis à vis its imperialist predecessor, especially since these late imperialist notions of childhood continued into the early Soviet period. 
Sample schedule for feeding preschoolers:

Breakfast: 9:00- 10:00 am

1. cup of milk, bread roll or piece of bread

2. or cup of coffee with milk.

3. or Piece of bread with butter or bowl of kasha from milk, roll.

4. Lunch: between 12:00- 1:00 pm

from 2 hot dishes:

1. Small bowl of thick vegetable soup, grains or meat, smetana (sour cream) with flour

2. Kotletyi from potatoes, vegetables, grains, eggs or casserole, with sauce from vegetables or macaroni casserole, tvorog (cheese), noodles, with fruit sauce or milk-butter kasha.

Snack: around 3:00 in the afternoon

1. Bread

2. Small bowl of hot fruit jelly with sugar,

3. or cup of milk with roll or coffee with bread and butter. ${ }^{249}$

For Tikheeva et al, the central concern of children's everyday proper nutrition was ensuring that children were well-fed and full for the day. Advice literature warned against what was referred to as 'irrational feeding' (net ratsional'nogo pitaniia), which emphasized giving children appropriate food types and amounts for their bodies. ${ }^{250}$ It

\footnotetext{
${ }^{249}$ Morozova et al., Sovremennyi Detskii Sad, 75.

${ }^{250}$ Morozova et al., Sovremennyi Detskii Sad, 76.
} 
advised kitchen workers to pay careful attention to children's actual food and ensure its freshness. As a way to ensure proper rational feeding, child specialists developed specific plans and menus derived from scientific studies and medical advice. As evident from the schedule above and the table below, one of the primary food products in children's nutrition included starches--especially bread-- grains, generally products that filled them. They recommended that child institution staff distribute sugar and sweet products sparsely in the morning and late afternoon. While there was no question as to the appropriateness of grain and starch in a child's diet, specialists debated over the issue of children's meat consumption: "With animal protein [we] need to be careful with children at an early age. ${ }^{, 251}$ In general, child specialists agreed that children should only have minimal animal protein intake limited to once a day, suggesting that white lean fish is better for children's health. Despite their preference for fish as the primary animal protein dish, child specialists advised Kindergarten directors to be cautious in serving fish (or meat in general) because of the risks associated with choking on small bones. They warned that preschool-aged children had yet to develop proper teeth and jaw strength to efficiently chew cumbersome foods. Instead of serving whole pieces of meat, Morozova and Tikheeva suggested serving koteltyi (Russian meatballs), ruleti, macaroni casseroles, or vegetable casseroles, and kasha, where cooks could mix in grounded meat or fish to facilitate chewing. In following more with the concept of 'rational feeding,' child specialists advised that Kindergarten directors needed to be organized, logical, and have an understanding of how to obtain foods with the highest nutritional content according to its seasonal availability. Despite differences in food consumption according to season,

\footnotetext{
${ }^{251}$ Morozova et al., Sovremennyi Detskii Sad, 75.
} 
child-care specialists devised plans to guide Kindergarten directors the correct food intake for children during lunch time.

Table 1: Average daily food intake in Kindergarten/ Per Child ${ }^{252}$

1. Milk- 200 grams (1 glass)

2. Bread- 150 grams

3. Grains in day where there is no meat -65 grams

4. Grains with meat- 20 grams

5. Vegetables -200 grams

6. Potatoes-200 grams

7. Sugar- 30 grams

8. Butter- 30 grams

9. Meat or fish- 100 grams

10. Fruit- 100 grams

As stated above, grains and starches such as bread and potatoes were the main staples of a child's diet, while meat was regarded as a rather controversial food item for a child's consumption. Despite these child specialists' efforts to regulate food consumption in the Soviet Union, the regulations proposed in this state-published manual are limited in the way that they only cater to children in European parts of the Soviet Union. They represent an idealized version of how Soviet child-care specialists aimed to provide proper food and eating habits as part of children's cultural transformation. By eating the prescribed amounts of food, Morozova et. al. believed would ensure optimal health and function of children's bodies, and make them more attentive to learning. Over time and

${ }^{252}$ Morozova et al., Sovremennyi Detski Sad, 75. 
especially in the 1930s, food became even more pervasive in symbolic use in relation to children and ethnic minorities in official discourse as it would represent the Soviet Union's role in being the main provider of all Soviet citizens and especially children. “THERE WILL BE BREAD: REPRESENTATIONS OF FOOD IN OFFICIAL

\section{CULTURE"}

The 1938 issue of USSR in Construction's "The Soviet Food industry opens with a quote from A. Mikoyan, who was the Vice Chairman of the Council of People's Commissars of the USSR: “...socialism can succeed only on the basis of a high productivity of labor, higher than under capitalism, on the basis of abundance of products and of articles of consumption of all kinds, on the basis of a prosperous and cultured life for all members of society." 253

In Soviet official discourse, the Bolsheviks employed ideas of food and children simultaneously in order to declare the state's efforts in improving daily life for its citizens. Also, in Soviet propaganda, ethnic and child minorities were portrayed as having considerable access to all kinds of food and living a joyous life as a result. By portraying children and ethnic minorities in food campaigns, the Bolsheviks intended for children to understand that one aspect of their happy childhood was the availability of food and special food items, including, candy and ice cream that would symbolize national childhood treats.

The same edition of USSR in Construction features a montage of children eating ice cream captioned by a message of progress and food abundance: "Ice cream is becoming a common food delicacy of both children and adults...Ice cream was once a

\footnotetext{
253 “The Soviet Food Industry, USSR in Construction, No. 8, p. 2.
} 
luxury in Russia; now it is a common food article." ${ }^{254}$ Published at the height of Stalin's Terror in 1938, this image is emblematic of Stalinist culture, affirming the propaganda campaign of life becoming happier, especially for children. The Bolsheviks engaged notions of food in official discourse to depict how the as a state, they successfully met children's basic needs by rescuing them from starvation they would have experienced under Tsarist Russia. In doing so, they also created new consumption practices for children and incited them to gain desires for 'luxuries' such as ice cream, that according to the Soviets, had become an everyday item accessible to children. The discursive and idealistic transformations of luxury items to easily attainable ones reveals emphasized the Soviet triumphant break the past towards a modern welfare state of food abundance for children. Children's food items, such as candies and ice cream, represented important markers of a happy Soviet childhood.

While images of children's food consumption reinforced the idea of State protection of its population and children, the children themselves were used in official propaganda as symbols of abundance, progress, and population growth. The same issue of USSR in Construction features a photo of children and youths participating in a physical culture parade holding bread baskets and vases with signs that read: "SSSR, Strana i Izobilia"-(“USSR, Country and abundance"). Other images include one of a blond male toddler eating a candy bar, which represented the Soviet Union's steady population growth, health, and prosperity, thanks to the new age of the Soviet food industry.

254 “The Soviet Food Industry," USSR in Construction, No. 8, 1938, p. 2. 
Soviet messages and images of food abundance were also prevalent in children's literature. Children's books often discussed food topics ranging from national production, distribution and consumption. While instruction manuals directed adults how to organize the ideal eating place for children, children's books taught children how to comport in the stolovaia and emphasized the significance of the stolovaia as the locus for camaraderie, as was essential for the growth of the new Soviet child. The children's book Pervoe Maia (May Day, 1928, year of the start of First-Five-Year Plan) embodies the Soviet ideals of children's socialization in its chapter of the Pioneer club. In this vignette, there is an illustration of the children are gathered around a table. The text describes the plants and flowers decorating the "abundantly laid-out table" and features a dialogue exchange between children offering rolls, cakes, and pirozhi to each other, while they tell stories about May Day celebration all over Russia in both cities and villages, over a cup of tea. Thus, the stolovaia and the abundance of food were central to the Soviet childhood experience. As depicted in this book, the Bolsheviks imagined children independently socializing, celebrating soviet holidays while collective sharing food. ${ }^{255}$

\section{THE IMPERIAL COLLECTIVE}

While ideas of food abundance were central in Soviet official culture of childhood, they were also crucial to Soviet imperial discourses. According to Bolshevik ideology, the experience of food preparation and consumption was to be shared by all peoples of the Soviet Union. The everyday practices and habits of production and consumption were central to the Soviet modernizing progressive projects, especially in unifying the disparate peoples of the RSFSR. As discussed in previous chapters, the

${ }^{255}$ A. Barto, Pervoe Maia (Moskva: Gosudarstvennoe izdatel'stvo, 1928). 
Soviet nationalities campaign allowed for political, cultural, and linguistic autonomy in the separate republics. For children in Kalmykia, as well as other parts of the empire, while allowing for some ethnic autonomy through the nationalities campaign, Bolsheviks intervened in their everyday lives in space and hygiene which would level or assimilate them more into Soviet (and into a certain extent Russian, culture). State propaganda exhibited the ideals of the campaign with photography and narratives of the changes in the populations' food practices in culinary skills, and especially in food preparation and modern forms of food production with new skills and access to technology, such as the introduction of tractors in collective farms. In its discussion of establishment of food plants, an article in USSR in Construction explains how the workings of the Soviet food industry is a collective effort by the peoples of different republics and nationalities:

"The raw materials needed by these plants are now available in abundance. They are supplied by the hundreds of thousands of collective farms and state farms of our country. The collective livestock and dairy farms of Siberia, the collective fisheries of the Far East, the collective and state tea plantations of Georgia (...) produce a great quantity of high -grade raw materials for food factories of the Soviet Union."256

Images and narratives of ethnic populations' relation to food also extended to ethnic minority children. Several propaganda journals, including USSR in Construction, featured photos pictures of Soviet crèches and schools, where there are healthy round Koryak (indigenous people of Kamchatka in the far eastern region of Russia) babies eating at the table. ${ }^{257}$ This photo featured in the issue "Soviet Kamchatka" is

\footnotetext{
256“"The Soviet Food Industry,” USSR in Construction, No. 8, 1938.

257 "Soviet Kamchatka" USSR in Construction, No. 9, 1930.
} 
accompanied by a caption that claims that the region was "successfully fulfilling Stalin's behest" in meeting agricultural needs and thus acquiring "an abundant food supply."258 These types of photos, portraying the feeding of national minority children can also be seen in other contemporary journals and newspapers including Komsomol'skaia Pravda. The use of ethnic minority children and food were cultural signifiers and proof of not only the State's ability to modernize and provide for the people, but also of empire's health and prosperity. These images reinforced the ideology that the State would be the main caregiver or parent for children (and the malinki narod or 'little peoples') of the Soviet Union. State propaganda reinforced the state's paternal role and the establishment of the communal family portrayed in the 1920 s and 30s (respectively) of Lenin and Stalin as father figures (notably "Papa Stalin”). ${ }^{259}$

Soviet children's books also featured images and rhetoric of empire and food. The children's book Nashi Tropiki (Our Tropics) which emphasized the notion of the collective imperial, by narrating the story of how the fruits eaten in Soviet Union are grown in the lush tropics of Batum, Georgia. Subsequent pages include stylized paintings of Georgian men and women (characterized by their traditional dress) in various food production roles, either collecting tea seeds in the state farms, or collecting mandarins. Another children's book, Evreiskii kolkhoz (The Jewish Collective), shows similar images of men and women involved in the process of food production. These images reinforced

\footnotetext{
258 “Soviet Kamchatka", USSR in Construction, 1930.

${ }^{259}$ For more on the Stalinist cult of personality phenomenon geared towards children and the Soviet state's role as the main caregiver for children, please read, Catriona Kelly, Children's World, 108.
} 
and taught children messages of collectivity, hard work and cooperation, which were all essential characteristics of an ideal Soviet citizen. ${ }^{260}$

The above sources including the children's books, journal and manual were based on State ideals and were rather prescriptions of how schools, Kindergartens and orphanages should feed children. Propaganda was a discursive strategy that worked in one aspect of Soviet governance that concealed the actual experiences and the implementation of policies in actual practice.

FOOD AND DINING IN EARLY SOVIET KALMYK SCHOOLS: THE NATIONALITY QUESTION AND THE EVERYDAY TRANSFORMATION OF CHILDREN'S EATING PRACTICES

For the Bolsheviks, food consumption and production fell under the umbrella of imperial unity and health. Bolshevik propaganda and ideas claimed that all children in the Soviet Union would have regular eating routines and access to sweets and other items that would have otherwise been inaccessible in the Tsarist past.

Although the Civil War (1918-1921) was a cause of urgency in acquiring children's food provisions, children's food consumption and daily eating habits had actually been a central preoccupation of Soviet colonial officials in Kalmykia since the first years of the Revolution. As early as 1918 the Kalmyk OBLONO (District department of education) had been careful in selecting foodstuffs for foster children and boarding school students. Soviet officials were sensitive to national dishes and culture.

The everyday (povsednevaia) foods of the pre-Revolutionary Kalmyk household consisted of milk that was homemade and cooked from their products, including, butter,

${ }^{260}$ L. Bruni, Nashi Tropiki, (Moskva: Molodaia Gvardiia, 1931); G. Ryklina, Evreiskii Kolkhoz, (Moskva: Molodaia Gvardiia, 1931). 
and smetana (sour cream). Kalmyk tea (Kalmyitskii chai) was the most important milkbased dish consumed in the Astrakhan region was central in Kalmyk nutrition and daily eating rituals. Its composition is made of boiled milk combined with butter and salt, usually accompanied with a small cake (lepeshka). Kalmyks adopted this practice from its neighbors to the east- Mongolians, as well as south in the Caucuses. ${ }^{261}$

Meat tended to comprise a large portion of the Kalmyk diet and was consumed on a daily basis. Depending on the region, Kalmyk cuisine either included more milk in its dishes, as it did in the Volga region, or more fished-based meals as in the Caspian area. For Kalmyks, lamb was the most common and favored meat, and even considered it valuable for its medicinal properties. Other forms of meat Kalmyks consumed included boiled and baked sheep organs (namely the heart and kidney). Certain sheep parts were distributed to different family members according to age, sex and position within family. For example, lamb shoulder (mutton) was given to the eldest or most revered male guest. The eldest man in the consumed the largest and roundest sheep bone, while the eldest women consumed the femoral bone. Young girls received brisket and were given long vertical cuts of the heart, while boys ate kidneys and ears.

Russian influence in Kalmyk cuisine began in the nineteenth century as the interactions between tsarist officials and Kalmyks increased. As a result Kalmyks increased their consumption of potatoes, onion, cabbage and their own version of Russian dumpling dish called buregi. ${ }^{262}$

\footnotetext{
${ }^{261}$ U. E. Erdniev, K.N. Maksimov, Kalmyiki: Istoriko-etnograficheskie ocherki. (Elista: Kalmyitskoe Knizhnoe izdatel'stvo, 2007), 289.

${ }^{262}$ U. E. Erdniev, K.N. Maksimov, Kalmyiki, 292.
} 
While the Bolsheviks intended to revamp Kalmyk children's everyday food consumption habits, they continued to allow some Kalmyk traditional foodstuffs well into the Revolutionary period. Items featured in receipts and order lists prior to the 1920s included various staples (sugar and especially flour). For example, the listed foodstuffs differentiated between Kalmyk tea (milk, butter, spices served in a bowl) and Russian tea (black, loose-leaf tea sweetened with jam and served in tea mugs).

Another instance in which Soviet officials catered to ethnic sensibilities in the early stages of the revolution was that they had ordered lamb, a crucial staple in Central Asian cuisine, in children's schools. ${ }^{263}$ However, the local officials in Kalmykia ordered and distributed meat for children on a daily basis which clashed with the state manual's proscription against meat, especially red meat, to children. Therefore, in Kalmykia, the early revolutionary practice of ordering foodstuffs for children was determined by their ethnicity as well as the Soviet food prescriptions, a practice following the mandates of the Soviet nationalities campaign. Variations in food consumption were not limited to meat or drink but also with more subtle food stuffs such as spices. For example, the Leningrad-based publication did not indicate for young children to consume distinct spices. However, in the Kalmyk oblast many Kindergartens, children's homes, and boarding schools often ordered special garnishes including tomato and onions. While the state manual recommended that children consume eggs, cheese macaroni, kasha, tovog (soft cheese), noodles, and jelly, none of these items appeared in any of the order sheets or receipts from Kalmyk oblast schools within the period examined.

${ }^{263}$ NARK, f. R-25, o. 1, d. 17, “Anabzhenie shkol”, p. 3, 23, 25. 
After the Civil War, the children's institutions in Soviet Kalmykia discontinued ordering lamb as the choice meat. However, most schools, children's homes, and orphanages continued to order Kalmyk tea on a regular basis throughout the 1920s. Although Kalmyk tea was less frequently ordered in the 1930s, there was still some retention of local-specific or ethnic food orders. The continuation of children consuming Kalmyk tea is not surprising, particularly in the decades of the 1920s. Early in the revolution, Lenin introduced a nationalization plan that would allow ethnic minorities throughout the Soviet Union to practice their cultural traditions as long as they adhered to Soviet regulations. ${ }^{264}$

Despite the local particularities of regional foodstuffs, the overall goal of the Kalmytski Oblasti Narodnogo Obrazovaniia (KONO) was to establish a sense of uniformity in the daily routine of children's eating habits that paralleled those in Moscow schools. These changes reflected the Bolsheviks' move to 'modernize' (i.e., eradicate traditional practices through scientifically-designed diets) and 'civilize' (i.e., incorporate the use of Western utensils to conform with European social practices) Kalmyk children's eating customs. While K ONO paid attention to ethnic distinctions of local foods they were also sensitive to distributing the appropriate food portions according to children's ages. Like with Western European child experts such as Maria Montessori, the Bolsheviks and K ONO acknowledged distinctions between children's age groups and accordingly designated proper nutrition requirements for healthy children. According to Soviet officials' sources in Kalmykia, childhood was defined as a period between 1 and

\footnotetext{
${ }^{264}$ Terry Dean Martin, Affirmative Action Empire: Nations and Nationalism in the Soviet Union, 1923-1939 (Ithaca: Cornell University Press, 2001).
} 
16 years of age, and divided it into three different age levels ranging from 1-3 years, 3-7, and 8-16 years. KONO intended for children in their respective age groups to consume a set amount of calories that increased with age. ${ }^{265}$ While Kalmyk school officials made a concerted effort to follow state norms, in 1921, as one inspector discovered, not all Kalmyk children's institutions complied with ensuring children with proper nutrition.

In the Kabzinev Children's Home, the inspector observed and described the feeding schedule as such: Between eight and nine in the morning children ate half a slice of bread, bowl of Kalmyk tea, or cocoa on Sundays. For lunch, which took place between two and three in the afternoon, children were served bread and a bowl of meat soup with a piece of meat. In the evening between the hours of 6 and 7, they were given tea and cakes. In other children's institutions including, the Kanav children's home, which housed children from 12-16 years old, care givers often served meat soup for lunch, while the children in the Kalmyk bazaar were "well fed" all day, especially during lunch with meat soup and a generous portion of meat. However, not all children's institutions succeeded in meeting demands for children's nutrition in Kalmykia. One inspector complained that the children's home "Third International" lacked important staples such as flour and meat. ${ }^{266}$

As evidenced in the report, Kalmyk children were expected to consume large quantities of flour and, to a certain extent, meat. The inspectors' observations of School No. 4 in bazaar 6/7 indicate that meat continued to be considered a major food source for

\footnotetext{
${ }^{265}$ NARK, f. R-25, o. 1, d. 114, “ KONO Kamytski Narodnogo Obrazovanie Sots vos 1921-23; "Normoi pitania detskoi vozraste ot 1 goda do 3. 3-7; 8-16," p. 12.

${ }^{266}$ NARK, f. R-25, o.1, d. 116, “Doklad, 1921,” p. 163.
} 
Kalmyk children in the early 1920s (during the inception of the nationalities campaign). Because meeting state regulations of the nationalities campaign was so crucial, in part of the Soviet child civilizing process, the few local children's institutions' failures in not being able to provide meat for children, highlight the impoverished state that the school was in for not being able to provide children with what was considered to be a staple food item in the Kalmyk oblast and in its culture.

In the mid-1920s, Soviet officials in Kalmykia for the most part, continued ordering the same foodstuffs for children. Flour remained the primary food item that local officials ordered, closely followed by starch. Food items such as flour were most likely ordered for their affordability as they were relatively inexpensive and were an efficient food staple to keep children well-fed for longer periods of time. ${ }^{267}$

Kalmyk tea remained the second most ordered item at this time. In May 1925, the Avanietrovskaia Boarding School spent 112 rubles 50 kopecks on Kalmyk tea, (second to flour with 232 rubles). ${ }^{268}$ For Kalmyks, food was central to their culture and essential for raising healthy children. Under the early Bolshevik regime, not only were children retaining a sense of their Kalmyk heritage in their food consumption, but they were also increasingly exposed to Russian food and drink, thus following more similar eating patterns as their Moscow and Leningrad counterparts. As shown in lists tallying ordered food items in children's homes over the course of the 1920s, the amount of meat

\footnotetext{
${ }^{267}$ NARK, f. R-25, o. 1, d. 17 1. 3-25."Snabzhenie shkol otdelnnyikh uch-sya” 1918-1920. "V prodvolbstvennyi otdel"- "Forwarding the list of products of the first necessities for the foster children (vospitannika) and boarders and also a list of schools in the Kalmyk steppes including the number of foster children in them. Also see NARK, f. R-25, o. 1, d. 17, 1. 43 "V Gubzagotosal", which features a request of 30-40 boarding schoolings asking for provisions and food for 1,500-2,000 people.

${ }^{268}$ NARK, f.R-25, o. 1, d. 468, “O pomoshei detei golodaishikh:Maloderbetovaskii ulusshkola, 1925,” p. $67-174$.
} 
decreased, there is no evidence of lamb or particular Kalmyk cuisine and even the consumption of Kalmyk tea reduced. Instead there is a rise in potato and grain consumption and an increase in purchase of flour. ${ }^{269}$

In the early 1930s, many of the food items Kalmyk children consumed remained the same as in the previous decade. The Rabotnikov Detdom (Workers' Children's Home) ordered similar food products, such as Kalmyk tea. In the month of August alone the Rabotnikov Detdom spent over 40 rubles 20 kopecks on Kalmyk tea. ${ }^{270}$ In another month, school officials ordered the local fish Ide (Yaz') which is native to the Volga river basin. ${ }^{271}$ Although Kalmyk children's institutions continued to have retention of local foods, changes Kalmyk cuisine slowly increased over time as receipts and logs showed more frequency in commonly ordered foodstuffs in Moscow schools such as tomatoes, potatoes, cabbage, and Russian tea.

\section{CHALLENGES IN CHILDREN'S EVERYDAY FEEDING IN EARLY SOVIET}

\section{KALMYKIA}

As discussed above, local officials established food programs for Kalmyk children and orphans during the initial stages of the Revolution. However, the devastation left behind by the Civil War limited the KONO's ability to produce and distribute foodstuffs to children as it had once promised. As early as 1921 (right after the

\footnotetext{
${ }^{269}$ NARK f. R-25, o. 1, d. 252, 1. 49, 57, 58, 67-174."Spiski nuzhdaiyushkiaia doshkol'nikh detei na vyidachi posobiya na pitanie" (1924-1925" and f. R-25, o. 1. D. 243 1. 14, 36, , 1. 2"O Pomoshi galodaiushim detyam 1924-1925" and for the early 1930s f. R-95, o. 1, d. 37, 1. 13-186"Delo s Avansovanyi rabotnikov detdomov za 1932 god".

${ }^{270}$ NARK f. R-95, o. 1, d. 37, "Delo s Avansovanii rabotnikov detdomov za 1932 god”, “Tovarnaia Nakadia", "Rospiska," Advansovii Otchoiot", 13-174.

${ }^{271}$ NARK, f. R-95, o. 1, d. 37, "Delo s Avansovanii,” p. 168.
} 
war) the crisis of children's feeding was addressed in the Kalmyk oblast. The Committee for the Improvement of Children's lives appointed categories of feeding priorities for special needs persons. Officials identified orphans as first priority, followed by the other child population, then Red Army soldiers, and invalids. ${ }^{272}$ The Committee came to a consensus to designate two hundred million rubles for the improvement of children's lives, particularly for feeding. ${ }^{273}$ By putting children above Red Army soldiers and invalids, the Kalmyk officials recognize the centrality of children's place in the Soviet Union.

In 1922, the Regional department of Education and Science (ObLONO) released a report emphasizing the failure of the Soviet government to feed its children in the Kalmyk oblast. It complained that "the number of children's rations being distributed was less than the number of boarders. In the months of December and January there were 3,016 boarders and only 2,360 rations available." ${ }^{274}$ The report continued to outline food distribution in children's homes for the months of January and February of 1922.

\footnotetext{
${ }^{272}$ NARK, f. R-25, o. 1, d. 112, "Doklad: Zasedaniia Komissii po uluschsheniiu zhizni detei," 21 October, 1921 , doc 1 .

${ }^{273}$ NARK, f. R 25, o. 1, d.112, "Protokol: Zasedaniia Komissii po uluschsheniu zhizni detei," p.2.

${ }^{274}$ NARK, R 25, o. 1, d. 159, "Ukrastnie o poriadke ucheta i oshchetnosti snabzhenie vospitanikov detdoma instruktsii OblONO," p. 1.
} 
Table 2: Food Distribution in Kalmyk Children's Homes

$\begin{array}{llll}\text { January } & \text { (1921) } & \text { February (1921) }\end{array}$

(monthly average)

$\begin{array}{llcc}\text { Flour } & 203 / 2 & 25 & 30 \mathrm{f} \\ \text { Meat } & 8 & 22 \frac{1 / 2}{2} & 15 \\ \text { Fats } & 11 / 2 & 11 / 8 & - \\ \text { Sugar } & 2 / 3 \mathrm{f} & 3 / 4 & 3 \mathrm{f} 12 \mathrm{z} \\ \text { Coffee } & 1 / 8 \text { or tea } 1 / 6 & 1 / 8 & \text { Kal tea } 1 / 8 \mathrm{R} 60 \mathrm{~s}\end{array}$

Key 1 funt=1 pound

When compared to prewar levels, OblONO saw a decrease in food availability. While on the surface, the reductions seem minimal, the reality was that the numbers of food distribution slightly decreased during a time when the student population drastically increased over time, as a result of children losing parents during the Civil War.

Soviet Officials continued to work on the crisis of child famine through the years 1924 and 1925. The UNONO (Dept of People's Education) released records of the distribution of monies in the sum of 37,000 rubles for the jurisdiction of several districts in the Kalmyk oblast. On the basis of the figures from local officials, schools in the M. Derbotstkii ulus (district) received the greatest amount of money. Boarding schools in general received top priority in the distribution of foodstuffs. The boarding school of the Derbotskii ulus, for example, totaled 5, 760 rubles because of the largest student body 
count of 300. Most schools received 32 rubles per child, further emphasizing KONO's policy to prioritize orphans first.

The KONO officials continued facing challenges in child food distribution. Stalin's collectivization campaign that began in 1928, in which ordered forced grain requisition to meet the demands of feeding the population was ironically the main factor in causing food shortages. Because Soviet officials in the countryside were met with resistance from the peasant population, either hiding the food, or purposefully sabotaging their crops, Stalin ordered the dekulakization campaign to rid the countryside of kulaks or rich peasants whom he claimed were responsible for the food shortages and class warfare. ${ }^{275}$ Earlier studies that have focused on food consumption in the Soviet Union continued to look at the political nature of food but have primarily concentrated on the famines that resulted from the Civil War or Stalin's Collectivization Campaigns. PostSoviet scholarship engaged social historical approaches to show how in reality, peasants were more resistant to state officials during collectivization. ${ }^{276}$ One Kalmyk male noted in his childhood during the early 1930s that his father had been forced to sell his house because of poverty resulted from collectivization. "Grain was taken from my family; we had to eat susliki (marmots) or otherwise we would have starved to death."277 On March 7, 1935, the Committee of Assistance of Agriculture and the Kalmyk Central Committee

\footnotetext{
${ }^{275}$ Ronald Grigor Suny, The Soviet Experiment: Russia, the USSR, and the Successor States (New York: Oxford University Press, 2011.

${ }^{276}$ Robert Conquest, The Harvest of Sorrow: Soviet Collectivization and the Terror-Famine (Oxford: Oxford University Press, 1986). Sheila Fitzpatrick, Stalin's Peasants: Resistance and Survival in the Russian Village After Collectivization (Oxford: Oxford University Press, 1994). Lynne Viola, Peasant Rebels under Stalin: Collectivization and the Culture of Peasant Resistance (Oxford: Oxford University Press, 1995).

${ }^{277}$ Harvard Project, Schedule B-5, Case 15, p. 2.
} 
agreed to release another 1,500 rubles and dedicate the sums to provide food for the "hungry and homeless" children. Despite the Bolsheviks' official rhetoric of meeting children's daily needs, lack of funding as V. Porokh critiqued Narkompros of in his report, and demographic crisis that Porokh described as a result of the Civil War, impeded their ability to meet the state's goals of providing proper nutrition for children's institutions. ${ }^{278}$ One Kalmyk male described his eating experiences when he was sent to the Gorki Children's Home, (which housed homeless Kalmyk, Russian, and Ukrainian children), between 1932 and1934. He explained the food shortages in the home in which resulted in a 'mass famine' of children whom three quarters of them died. As a result, he caught diphtheria, and credited his teacher's generous food donations for saving his life. ${ }^{279}$ Another Kalmyk male discussed his experiences of food shortage in a boarding school off the Caspian Sea:

"Conditions were bad; the students were poorly fed and some of them who did not have parents had to give up their education. There was especially a lack of bread and fats in 1929-1930 and during 1933, and it was forbidden to send any grain products by mail from home although fats could be sent." 280

The same individual noted that when he was transferred to a new predominantly Russian school in 1932 nearer to his home. He pointed out that the "food was bad," and when a student complained about the conditions and food to the director, he was punished for carrying out "anti-narodnaia (people) activity," and further deterred

\footnotetext{
${ }^{278}$ NARK, f. R-25, o. 1, d. 468, "Dogovor: O pomoshchi detei golodaiushikh:, p. 2.

${ }^{279}$ Harvard Project, Schedule B-5, Case 23, p. 6.

${ }^{280}$ Harvard Project, Schedule B-5, Case 15, p. 1.
} 
students from protesting about the food conditions in school. While at the school, his father supplied him with dry bread to ensure some form of regular sustenance. This man's case with his father supplementing his food further emphasizes Porokh's reports and critiques of the Soviet system in not able to meet children's nutritional needs.

\section{SOCIALIZATION IN THE KALMYK STOLOVAIA}

While the food items consumed by children retained many of their Kalmyk traditions, the stolovaia, or overall environmental experience, changed towards a more modern aesthetic, made with concrete walls and carefully-planned through architecture and science. Before the Revolution, Kalmyk cookware and utensils, like preRevolutionary Kalmyk cuisine, resembled more Central Asian objects than Russian. Kalmyk household utensils were mostly made of animal skin, wood, and metal, and included objects such as wooden triangular stands for boiling water or milk. Other popular household items included a large wooden pitcher, or dombo, to serve tea, while the cooked liquids were stored in ornate vessels. ${ }^{281}$ After the Revolution, local Soviet officials disregarded the use traditional Kalmyk household items in any children's institution and only used more 'western' types. In the kitchens of children's institutions, Soviet officials introduced new cookware, including cast-iron heating boilers that replaced the wooden Kalmyk ones used for soup, kasha, and milk. Thus, Kalmyk children and youths whether in school or in an orphanage would have been the first group of the population in the region to regularly encounter these 'new' types of dishware.

These changes in eating and food preparation tools reflected the Soviet ideals of civility-- including collective behavior and discipline--and modernization-carefully

\footnotetext{
${ }^{281}$ Erdinev and Maksimov, Kalmyki, 295.
} 
planned diets derived from doctors and professionals-- in eradicating backwardness through uniformity, by encouraging all peoples to learn to use the same types of objects. The everyday process of food preparation and eating together instilled a sense the ideal of collectivity, while the food contents represented more of Kalmyk or Central Asian cultural tastes. In the early 1920s, The Department of People's Education sought assistance from the district committee in order to provision 85 schools with eating utensils in the Kalmyk Autonomous Oblast. Requests included large, round plates, knives, tea mugs (all 8,500/ 100 per school) and 500 lamps. ${ }^{282}$

Local officials discriminated between the types of dining ware ordered for children. In fact, Kalmyk children's institutions' receipts and order logs distinguished between large plates, medium plates, bowls, and different beverage cups, so that they would be more accommodating for children's small hands. Kalmyk children also learned how to eat using foreign utensils including table knives, knives, forks, and spoons. Tea dishes, particularly the bowls used in drinking Kalmyk tea, were not necessarily replaced but were in addition to Russian sets such as the tea pots, small dishes, tea spoons, and tea cups, introducing more Russian customs into Kalmyk children's daily feeding routines. ${ }^{283}$

The Kalmyk child's everyday eating habits were not only transformed through material objects in terms of learning how to use new utensils, but also in their environment. An inspector's report released in 1921 specified how different children's

\footnotetext{
${ }^{282}$ NARK, f. R-25, o. 1, d. 17, "’Snabzhenie shkoli," p. 47.

${ }^{283}$ NARK, f. R 25, o., d. 259, "Smeta trebovanie", p. 8. There is an even more detailed and extensive list dishes and types of food ordered for children Also see NARK, f. R -95, o. 1, d. 37, "Delo s Avansovanyi rabotnikov za 1932," p. 31.
} 
homes in Kalmykia set up children's dining areas. ${ }^{284}$ Children's Home No. 1 (which housed children aged 5-11 yrs old) created a separate children's canteen, while Kireeva Children's Home (for youths, 12 to 16 years old) did not have separate stolovaia. However, the Kalmyitski Bazaar Home stood out in the report as the inspector emphasized how it has a kitchen and stolovaia for children. His fourth observation, the Children's Home The Third International included a children's stolovaia and a kitchen in the basement (though he does not specify whether it was for children). The Bazaar Home is the one that most closely resembled the State's Kindergarten manual's model of not only having separate feeding room for children, but also a kitchen for children to be able to participate in the food preparation process. A 1928 photo taken in the Malderbetskov Children's Home illustrated the changes that took place in Kalmyk dining patterns at least in children's institutions. In the photo, Russian and Kalmyk children are gathered around a child-sized rectangular table dressed in a white table cloth with round porcelain bowls, or plates in front of each child while some are holding spoons or some are crying, staring or talking to each other. A Kalmyk nurse supervises the children in the background while holding children from different ethnic backgrounds. (See Figure 7). Other than confirming the changes in Kalmyk children's eating practices, this photo evokes several images of Soviet official culture and especially that of the Soviet friendship of the peoples. ${ }^{285}$ The photograph presents other several factors in the State's role in child welfare, in the way it reinforces the official ideology of the State's new role in parenting children. State-run children's institutions replaced the family and established

\footnotetext{
$\overline{{ }^{284} \text { NARK, f. R-25, o.1.d. 116, p. } 4 .}$

${ }^{285}$ NMRK," Foto, Deti za obedem.”
} 
ideal nurturing environments that would facilitate in distributing food to children while shaping their eating habits. In this sense, the stolovaia signified for children a place to eat, socialize, while for Soviet officials it was a place that protected children and a space where they would acquire Soviet civility.

MOSCOW

While it is evident that local officials in Kalmykia made concerted efforts to promote ethnic practices according to Soviet laws, both locations, Kalmykia and Moscow underwent the same historical events including, the Civil War, New Economic Policy of a state socialist-market program, the Cultural Revolution, the FFYP and the Terror.

Like in Kalmykia, Moscow schools suffered from severe shortage and resorted to urgent cries for provisions during the Civil War period (1919-21). In 1920, The Preservation of Childhood agreed to meet the children's homes' demands for food. In response to the children's homes' requests, the agency responded by providing them mostly with potatoes. ${ }^{286}$ Other common food items children's institutions in Moscow asked for included sugar and groats. Groats, like potatoes, served as 'filler food.' Again, the goal of ensuring children were full during meals was paramount in Moscow as it had been in Kalmykia.

Also similar to feeding practices in Kalmykia, Moscow children's institutions were sensitive to food distribution and rationing according to age group.

${ }^{286}$ TsAMO, f. 6756, o. 1, d. 6, p. 41. 
Table 3: Food Distribution in Moscow Children's Institutions According to Age Group

\section{Age 3-8}

$22 \frac{1}{2}$

8

2

4

30

2

Sugar

Cabbage

Salt

Coffee

Onion

Seasonings

Eggs
Ages 8-16

30

10

2

$7 \frac{1}{2}$

45

2

1

1

$3 / 8$

60

90

According to the table, Moscow officials gave Moscow children very similar provisions to their Kalmyk counterparts, differing only in some local drinks and dishes ${ }^{287}$

At the Efimovskaia children's colony, directors also separated appropriate food amounts according to age group. Just as had been done in Kalmyk children's institutions, Moscow institutions added 'luxury' food items for children such as cocoa and candy.

${ }^{287}$ TsAMO , f. 6764, o. 1, d. 1 "Polozhenie ob upravelenie detstimi, 1921," p. 26. Children's meal schedules also differed by age in Moscow children institutions. 
During the 1933 Conference on School nutrition, (MOS GORONO/ Moscow City People's Department of Education), meeting members boasted, as typical in post-First Five-Year Plan fashion on their achievements in improving children's nutrition in school. Many officials claimed about the how the implementation of the canteen network increased by $275 \%$ and its ability to feed $92.5 \%$ of children. ${ }^{288}$ Conference delegates understood the space of the stolovaia as one of the most significant Soviet achievements especially when comparing itself to the West—a typical discourse in post-FFYP official culture. According to the Chair of the Children's Feeding Group, MosKormit, Tov. Popova claimed that the only way to reach the "necessary conditions for the future construction of socialism, ... [we] must especially take care of the children, especially in feeding." Popova supported her case of Soviet progress with statistics, and declared: "We now have 169 canteens that provide food to $100 \%$ full coverage of the child population. ${ }^{289,}$ She emphasized the comparison of a Soviet child's life with children from capitalist countries who had "hard" lives and endured child labor. In doing so, Popova reaffirmed claims of Soviet superiority and constructed the notion of Soviet space as being ideal for children, in the ways that there were special places designed for them, such as the stolovaia. In addition, Popova boasted that the Soviet Union was modern and superior in the way that Soviet schools housed doctors and child professionals who worked with children in devising an appropriate menu that children would enjoy. ${ }^{290}$

\footnotetext{
${ }^{288}$ TsAGM, f. R-528, o. 1, d. 29, "Stenogramma Konferentsiii po skholomu pitaniiu, sozvannoi Moskarpitam MosGorONO i Mosgorzdravom ot 9 fevralia 1933, p. 2.

${ }^{289}$ TsAGM, f. R-528, o.1, d. 29, p. 2.

${ }^{290}$ TsAGM, f. R-528, o.1, d. 29, p. 6.
} 
Just as the stolovaia in Kalmykia was established to set up a modern, collective environment that would resemble the ideal Soviet experience in food consumption, in Moscow, school officials made similar claims and declared that the stolovaia was an important pedagogical component to children's education, that extended "beyond the threshold of the classroom." ${ }^{291}$ Believing that it was an important factor in refining children's behavior, Popova argued that feeding time should be observed strictly and carefully by school directors and teachers. She complained, however, that many children's institutions, primarily schools, had problems in producing an environment that would facilitate conformity and socialization as a result of the overcrowding of space and lack of surveillance. According to Popova, the place of the stolovaia produced a time and environment where "eating is one of the special moments that has cultural knowledge in which [children could bring] these habits home. We know that the majority of our children in regards to table manners have terrible upbringing (vospitanii plokho)..."292 The stolovaia, for Popova and child specialists in Moscow, was a spatial opportunity not only to acquire proper social behavioral skills, but also an opportunity where children could be well-fed, since many complained of lack of feeding at home. ${ }^{293}$

Despite these auspicious proclamations, Moscow children's institutions, in reality, faced food shortage crises. Yet, unlike Kalmykia, some of the instances of the food shortages in 1930s Moscow children's institutions were usually a result of employee theft

\footnotetext{
${ }^{291}$ TsAGM, f. R-528, o.1, d. 29, p.7.

${ }^{292}$ TsAGM, f. R-528, o.1, d. 29, p. 8.

${ }^{293}$ TsAGM, f. R-528, o.1, d. 29, p. 23.
} 
as well as child neglect. ${ }^{294}$ In one case, Popova reported an instance where almost 2 kilos of butter and bread went missing from the kitchen. Continuing her observations, Popova reported that there were more school canteens that failed to meet state expectations than those that did. She also complained about the discrepancy in food distribution between districts. During one of her routine inspections, Popova asked the school cook why they failed to heat the kasha for breakfast. More problems appeared as her partner, who aided in the inspection, confronted a cook over why in one child's breakfast portion there were 2-3 slices of bread while the other one had none. The cook simply responded "there was not enough of it to give away.",295

The problems of everyday food distribution for children in Moscow institutions exacerbated over time, not only with theft, as a result of lack of care and proper preservation of children's foodstuffs. In one case reported on December 1932 in School No. 16, the distributors served breakfast millet patties and compote on a day when the majority of children failed to attend school because of the freezing temperatures. Rather than cooking new meals, the same food was reheated and given out the next day.

\footnotetext{
${ }^{294}$ TsAGM, f. R-528, o.1, d. 29, p. 7.

${ }^{295}$ TsAGM, f. R-528, o.1, d. 29, p. 7.
} 
Figure 7: Example of Outdoor Stolovaia in Kalmyk Children's institution (Presented in accordance with Fair Use Law 17 USC section 107): ${ }^{296}$

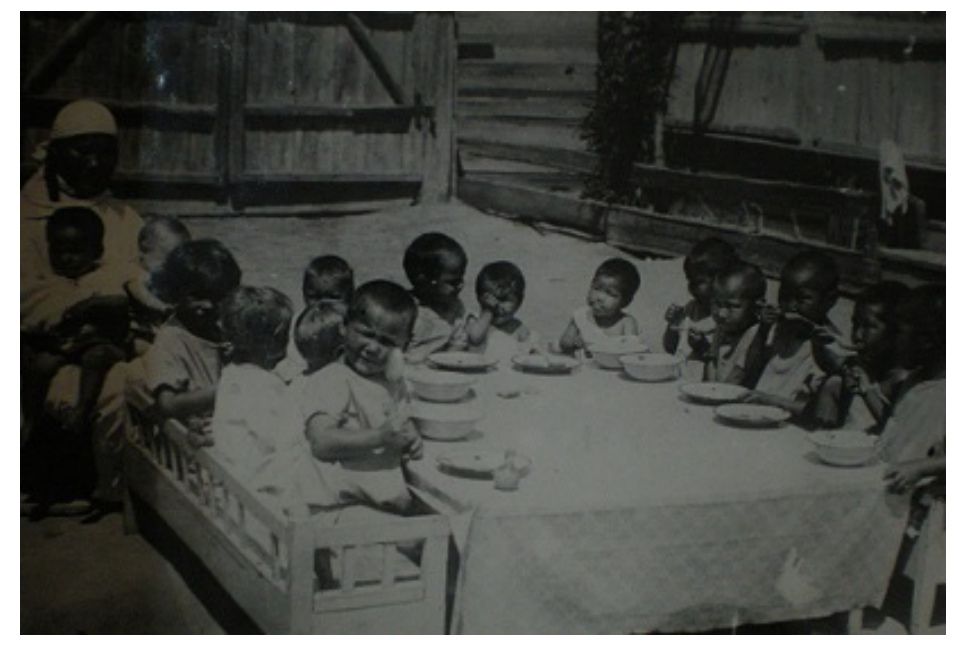

Figure 8: Example of Outdoor Stolovaia in Moscow Kindergarten (Presented in accordance with Fair Use Law 17 USC section 107): ${ }^{297}$

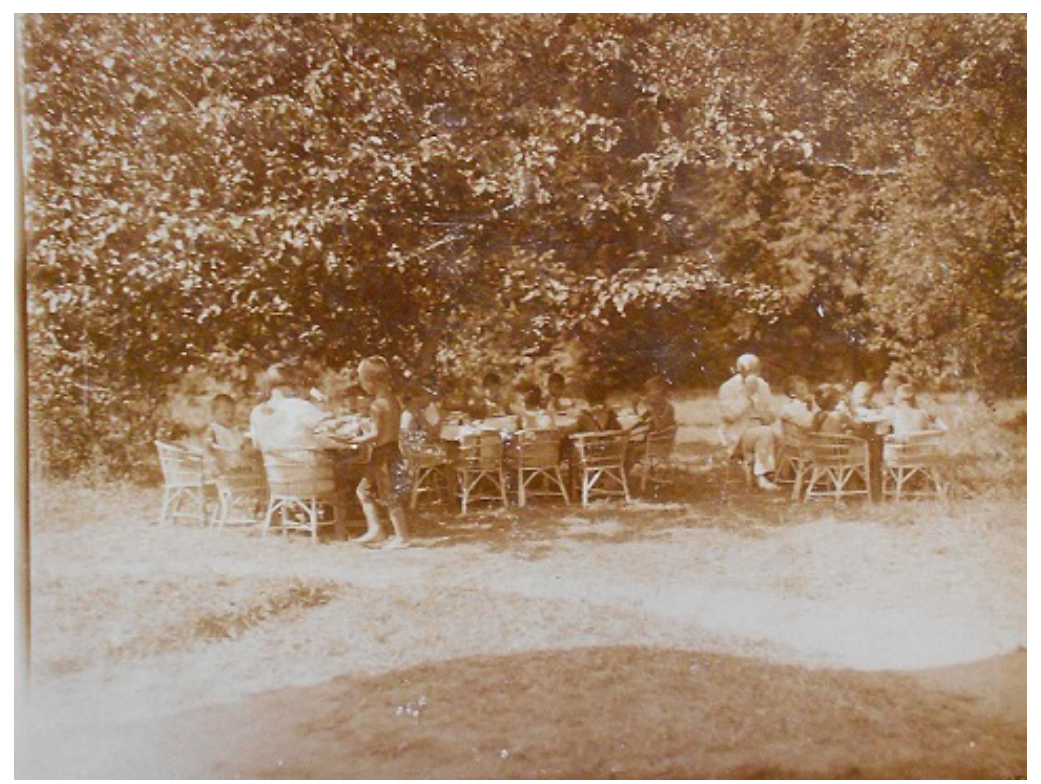

\footnotetext{
${ }^{296}$ NMRK: 1457/ 17“Deti za obedem”, 1928.

${ }^{297}$ TsAMO, f. R -587, o. 4, d. 8, "Fotografii detskikh sadov," 1920 s.
} 


\section{CONCLUSION}

During the early revolutionary period, the Bolsheviks made several attempts to keep to their promises: there was indeed 'bread' in the Soviet Union and in Kalmykia. Through the constructions of places for children's dining and constant ordering of foodstuffs, it was evident that food was central to the Soviet projects of rescuing children from hunger, backwardness, and over time ensuring them a happy childhood throughout the empire. Yet, these Soviet dreams of food abundance and campaigns to reach all hungry children in the empire were blocked by historical events early in the Revolutionary period, especially with the onslaught of the Civil War that lead to budget crises, food shortages, and a sharp population decline, increasing the amount of orphans and needy children. All of these events were products of political decisions, cultural interactions and social policies that intended to keep the promise to feed the whole population and protect children.

While food consumption in Kalmykia kept some of its pre-1917 traditions, children's dining spaces and habits were revolutionized. For Soviet officials in Moscow and in Kalmykia, food was more than a source of nutrition and health. Food became a core component of Soviet ideology representing the health of the empire and the success

of the Socialist Project. Furthermore, Soviet ideology used food as an instrument to unify the various populations of the Soviet Union, primarily by focusing on how food was an object that took collective effort to plant, harvest, and store. With the combination of the technological innovations and intentions of mass consumption of food, the Bolsheviks used food not only as a way to unify the empire but also to modernize it. These notions 
of the collective work effort and production were cornerstones of Soviet citizenship and modernization that would also reach children.

In general, the case of Kalmyk children's institutions teaches us how there was a concerted effort to meet state ideals in terms of children's proper eating both in food consumption and in environment. The Bolsheviks not only intended to feed children throughout the empire, but had a very specific plan or distinct use with food items and food consumption. Soviet officials wanted national minorities to also engage in the Soviet social project whether aiding in preparing meals in the kitchen or eating together in a large table, sharing food and stories. For Kalmyk children, exposure to the new Russo-European eating customs, such as using utensils, and drinking Russian tea, and keeping a strict eating schedule at their orphanage, school or Kindergarten, slowly transformed their daily habits from old Central Asiatic traditions into those that resembled their Russian counterparts in Moscow. Despite retaining some of their local ethnic identity, Kalmyk children over time became more accustomed to eating Russian cuisine, using Western-style utensils and cookware during meals and meal preparation. Bolsheviks intended for national minorities to embody a Soviet persona through these new practices that over time would take over local customs and culture, and inscribe in them (or require in them) a new Soviet character with an acquired taste for Russian and European cuisine and manners, and a creation of a new, Soviet childhood that resembled Muscovite children's. These 'new' tastes and manners would not be limited to bodily habits and practices but also acquired through lessons in historical knowledge and even more significantly in Russian language acquisition. 


\section{CHAPTER V: INTO THE LIGHT: LANGUAGE AND CULTURAL}

\section{ENLIGHTENMENT IN SOVIET SCHOOLS}

"What awaits you, descendants of weak Oirats, death or renovation?" - (from the list of duties in the Kalmyk Autonomous Oblast in schools and education) $)^{298}$

The haunting question, posed in the conclusion of an inspector's report in Kalmyk schools in the early 1920 s is telling of one aspect of the Soviet Union's urgent desire to modernize the education system, especially for children. It aims both aims to show how the Bolsheviks took an active role in transforming Kalmyk children's everyday lives and to blame on the Kalmyk peoples themselves for their own 'backwardness,' particularly in terms of literacy and language. It also gives Kalmyks the responsibility to dictate their own future, will they choose death over progress, as defined by the Bolsheviks? (Will the young generation save them?)

While the Bolsheviks focused on the care of children's bodies inside and out to instill disciplinary habits that complemented Soviet modernization projects, they also paid careful attention to the child's mind, combining intellectual and cultural education primarily through language study. Language was the part of the Soviet socialization process that was accompanied with set schedules and activities. Yet language acquisition was also without limitations, in the sense that the children in Kalmykia and other parts of the Soviet Union confronted these changes and practices in their homes, schools that became a defining characteristic (or legacy) of Soviet rule during the longevity of the Soviet empire and beyond. Language acquisition was a thought process, like (the new soviet habits) that was pervasive in projects to socialize and build character. It was an

\footnotetext{
${ }^{298}$ NMRK, V. Porokh, “Otchet o deitel'nosti otdel narodnogo obrazovanie,” (July 1921), p. 39.
} 
everyday practice that would become the ultimate key for the 'creation' of a successful citizen in the Soviet Union. While the Bolsheviks allowed for simultaneous learning of native language during Russian language acquisition, it became increasingly more demanding to have mastery of Russian. For Kalmyk children, learning Russian began in the second year of elementary school and would continue through their remaining educational career, and thus break with their parents' "dark" past. The Sovietization (taking on characteristics of what was deemed as Soviet) of language for Kalmyk children resembled more of their Moscow counterparts' education in the sense that they were not just learning "Russian" in its pure form, but a different, rather "Sovietized" version of it. For example, not only did the children learn the Russian language, but had to learn new vocabulary words such as "collectivity."

In short, the Bolshevik project of language acquisition in both native and Russian language as a way to instill Soviet values and civility among children. Over time, school officials faced similar challenges in teaching proper language and grammatical skills to children in both Kalmyk and Moscow classrooms. Part of the implementation of these projects was the literacy campaign directed towards children and youths around the Soviet Union. The Bolsheviks consciously identified the literacy campaigns as a defining factor of the Soviet modernization process, along with technological innovations and industrialization.

Childhood perspectives from Kalmykia and Moscow reinforce the similar educational experiences of children in the early Soviet era. In these interviews from Soviet expatriates from Moscow and Kalmykia recorded in the 1950s, the subjects reveal an overall sense of rejection of state-mandated education and how they coped with the 
everyday educational policies. When carefully reading inspectors' reports, there tends to be other noticeable forms of everyday challenges even by parents, when children's school attendance noticeably declined. ${ }^{299}$ In fact, Soviet inspectors complained that these actions lead to Kalmyk children's exposure to Russian language to become more limited and perpetuate the region's so-called backwardness or stagnation.

Over the course of the revolutionary period, the official press emphasized the importance of literacy and publicized newly constructed libraries around the RSFSR, which became evidence of small victories that reinforced Soviet progress. It simultaneously warned against 'alien' forms of teaching in the classroom. In the meantime, Kalmyk inspectors and instruction guides equated children's poor reading and language skills to 'disease."

In early Soviet Russia, as was true with leisure, hygienic routines, and feeding, language and reading state-produced and sanctioned- literature served to shape not only New Soviet Man, but child. While the other activities played important roles in both Russian and non-Russian children's development, language stood at the heart of

\footnotetext{
${ }^{299}$ For more on approaches to recover subaltern voices please see: Gaytari Chakravorty Spivak, "Can the Subaltern Speak?" in The Post-Colonial Studies Reader, ed. Bill Ashcroft, Gareth Griffiths, and Helen Tiffin (London; New York: Routledge, 1995), 24-28. Thomas Ewing, The Teachers of Stalinism: Policy, Practice and Power in Soviet Schools of the 1930s (New York: Peter Lang, 2002); Thomas Ewing, "Restoring Teachers to Their Rights: Soviet Education and the 1936 Denunciation of Pedagogy in the History of Education Quarterly vol 41 no 4 (Winter 2001): 471-93. In his study, Ewing focuses on the anti-pedology decree of 1936, that eliminated the entire field of pedology, including NARKOMPOS. Pedologists were blamed for the failures of the Soviet school system. The state accused them of corrupting the school system with 'bourgeois'-style education especially when it came to labeling the children as 'retarded' or 'deficient.' While the pedologists were denounced, the teachers gained more autonomy in instruction. For Ewing, however, this created a paradox: while teachers had autonomy, they were also held even more accountable for students' failures. Teachers who questioned the state ideology of all pupils are equal in aptitude, were considered as enemies of the state and were threatened with arrest. This resonates with Fitzpatrick's Everyday Stalinism. He concludes that teachers' willingness to conform to state policy also made them agents in perpetuating the oppressive system. This chapter finds similar incidences in Moscow and Kalmykia, further showing the commonalities across the Soviet Union in terms of projects for children and education.
} 
Bolshevik imperial policies, especially that of the nativization (korenizatsiia) process. ${ }^{300}$ Language was at the core of children's everyday experience, and most central in the way that it shaped the mind through constant communication. However, the other factors, including, food, clothing, beds, shaped children's bodies and their minds through transformations that the Soviets perceived as more modern and appropriate to Soviet culture.

Before delving into more theoretical explanations, it is important to understand the various uses of language in the context of Russian minorities and the purpose they served in transforming local populations. In the case of schooling national minorities in both Imperial Russia and the Soviet Union, establishing Russian as the common language provided a venue for teachers to be able to communicate with their students, which in the case of Soviet Russia, with the Soviet policy of allowing ethnic communities to practice their native language, made teaching Russian to children more challenging. For imperial systems, including those of Tsarist and Soviet Russia, language acquisition was not only about learning Russian but introduction of new words that introduced new concepts and new ways of life that were distinctive to that of the colonizer. ${ }^{301}$ The imperialist language acquisition concept was also true for children in the sense that children, regardless of ethnic background, became exposed this 'new' language of Soviet, that would shape their minds, and instill in them new ways of thinking such as learning new terms like "socialism.” Even though Russian children living in Moscow and Leningrad

\footnotetext{
${ }^{300}$ Michael G. Smith, Language and Power in the Creation of the USSR, 1917-1953 (Berlin; New York: Mouton de Gruyter, 1998).

${ }^{301}$ Michael S. Gorham, Speaking in Soviet Tongues: Language, Culture and the Politics of Voice in Revolutionary Russia (DeKalb: Northern Illinois University Press, 2003).
} 
(for example) obviously spoke Russian, they also had to learn the language of "Soviet." Historians have explored the wedding between ethnic cultural groups and Sovietization. In his study, Jeffrey Veidlinger examines how the Jewish theatre functioned in the Soviet Union during the nationalities campaign and its ability to promote Jewish culture, by combining elements of Soviet ideals. Veidlinger explains how language was one of the factors that were affected during this process by noting how the "Yiddish language was purged of 'Hebraisms' just as Uzbek and Tartar were purged of 'Arabisms' and 'Farsisms. ${ }^{302}$ The process of purifying the Yiddish language, by ridding it of its preRevolutionary elements, resulted in the creation of a modern discourse. ${ }^{303}$ In a 1929 Komsomol'skaia Pravda article, the reporter noted how the modernization of the Arabic language enabled Tartars to become more successful:

"The Arab alphabet does not conform to culture and economics for them. It was too expensive to manage and was not adaptable to typewriters, but only to handwriting. Today the alphabet has great success not only among workers and peasants, but also in the circles of old Tartar intelligentsia." ${ }^{304}$

The topic of Soviet education has been extensively researched in Cold War scholarship, but not until post-Soviet era do studies in language and literature among both Russian and English-speaking scholars increase. The use of Russian language for empire-building, like its Western counterparts (i.e., British India), signified superiority,

\footnotetext{
${ }^{302}$ Jeffrey Veidlinger, The Moscow State Yiddish Theatre: Jewish Culture on the Soviet Stage (Bloomington: Indiana University Press, 2000), 5.

${ }^{303}$ Veidlinger, The Moscow State Yiddish Theatre, 20. According to Veidlinger, the Russian language itself underwent similar transformations during the early Revolutionary period, by being purged of bourgeois, $19^{\text {th }}$-century vocabulary and thus become more Soviet.

304 “Molodoezh Tatary v Bor'be,” Komsomol'skaia Pravda, June 26, 1929.
} 
civilization, and modernization, while leaving minority or indigenous populations as 'othered,' or backwards, and only through attaining mastery of the imperial language could minorities gain some political and cultural legitimacy. ${ }^{305}$ In the case of Soviet Russia, (as with English in British India or Spanish and Portuguese in Iberian colonial America), Russian became the conduit for communication in political, social, and cultural arenas and institutions, which would serve to unite the population gaining access to an imagined community through language. ${ }^{306}$ The relationship between language and authority or power, was not solely a top-down process. Learning Russian empowered non-Russian minorities and therefore, non-Russians sought opportunities to learn Russian, including for their children in schools in national republics. Although national minorities were subjugated, by learning the lingua franca and familiarizing themselves with the Soviet system, minorities took advantage or used it to their own benefit. For example, a Kalmyk who learned Russian in the early Soviet period would eventually have access to political colonial post or hold more prestigious jobs and positions. Of course, Kalmykia was not the only location where these programs were implemented, nor did they only take place during the Soviet period.

Scholars have noted that these imperialist policies of Russification of minorities had its origins in Pre-Revolutionary Russia. Tsarist officials instituted the Il'minskii

\footnotetext{
${ }^{305}$ For more on the concept of "Othering", please see Edward Said, Orientalism (New York: Pantheon Books, 1978). In Orientalism, Edward Said constructs the notion of orientalism as a historical, intellectual, cultural and philosophical development that primarily characterizes Western attitudes towards the East between 19th century for Britain and France until WWII and America after WWII. According to Said, the notion of 'Orientalism' is a tactic consciously or unconsciously used by Western colonist to define themselves in what they are not. In other words, by juxtaposing their culture to the Orient they can emphasize their superiority and advancement.

${ }^{306}$ Benedict Anderson, Imagined Communities: Reflections on the Origin and the Spread of Nationalism (New York: Verso, 1983). While Russian became the dominant language, the Soviet Union officially declared itself multi-lingual.
} 
method of schooling minorities through native language. The Holy Synod approved this type of schooling because it still taught Orthodoxy, which they believed was the first step to Russification. Officials working in Russian-Tartar schools eventually saw that religious conversion of Muslims was unattainable and impractical and lead to violent forms of resistance from the local populations. As a way to remedy the situation, officials adopted more secular forms of education in Russian language, These forms of cultural change would eventually lead to eager acceptance of the Orthodox religion, finding that "the ideal of complete Russification was never as widespread as rhetoric made it seem. ${ }^{307}$

The relationship between language acquisition, literacy, and imperial policies cemented proper notions of civility in an emerging literate public. New forms of language and literacy programs promoted under Catherine the Great (in late eighteenth"century Russia) and throughout the course of Russian and Soviet history were designed to create or instill proper habits for the ideal citizen. These programs reflected the ideals of the Enlightenment and values of civility and were passed down even well into the Soviet era with the emergence of kul'turnost (culturedness), which was the notion of individual selfeducation and self-improvement. The idea of kul'turnost resulted in the transforming of "everyday conduct into a controversial and intricately idealized question" of selfconscious behavior. ${ }^{308}$ The press was one aspect of Russia's modernization process during the Era of Great Reforms in the mid to late nineteenth century. The Era of Great

\footnotetext{
${ }^{307}$ Robert P. Geraci, Window on the East: National and Imperial Identities in Late Tsarist Russia (Ithaca: Cornell University Press, 2001), 346.

${ }^{308}$ Catriona Kelly, Refining Russia: Advice Literature, Polite Culture, and Gender from Catherine the Great to Yeltsin (Oxford: Oxford University Press, 2001), xvi, 80.
} 
Reforms was marked with the rapid rise of industrialization and urbanization in the country that resulted in the peasant migration to the cities. During this time, the presses developed new forms of literature that catered to the lower classes and thus transformed the once illiterate peasantry's oral tradition of telling stories to one with printed word. ${ }^{309}$

The language policies established for children throughout the Soviet Union were under the purview of Narkompros and in the case of Kalmykia, K ONO (Kalmykoi Odtel Norodnogo obrazovanie/ Kalmyk Department of People's Education). A central component to Narkompros and the K ONO was to mold children from what seemed to Bolshevik officials as backwardness-- bringing them into the light with literacy and transforming their attitudes and world outlook with the acquisition of Russian language. The same was true for children in the multi-cultural, urban capital of Moscow. Even the children in the classroom who were native Russian speakers still had to acquire new forms of language - Soviet — in order to become closer to the ideal citizen.

\section{HISTORY OF SOVIETIZATION OF LANGUAGES}

Extensive studies have already been done on the development of Soviet language policies. Soviet leaders understood that they would be unsuccessful if they controlled the population solely through force. They needed to establish alliances with national minorities in order to retain the pre-Imperialist non-Russian territories, and did so by claiming an anti-colonial stance. In order to solve the problem of having the support of ethnic minorities, the Bolsheviks set up the Commission for the Study of Tribal Composition of the Population of Russia in an effort to "combat backwardness"

\footnotetext{
${ }^{309}$ Jeffrey Brooks, When Russia Learned to Read: Literacy and Popular Literature, 1881-1917 (Princeton: Princeton University Press, 1985).
} 
(Komissiia po izucheniiu plemennogo sostava naseleniia Rossii KIPS). ${ }^{310}$ Unlike their Western counterparts who used biology and race to determine 'backwardness,' Soviet ethnographers defined backwardness according to a group's social and historical place in the Marxist trajectory and believed that they would, in time, evolve to more 'modern' forms of living. ${ }^{311}$ Language was one of the factors that would 'evolve' in respective ethnic groups.

Soviet language policies adopted the Marxist theorist Nikolai Mar's writings. Mar believed that language was linked to genetics and this concept was used in the creation of the nativization language programs throughout the Soviet Union, which allowed for national ethnic minorities throughout the Soviet Union to practice education and local politics in the native language at home. However, increasingly over time, Russian became the primary language in the major institutions and in the 1930s becomes more prominent in smaller institutions. In the mid-1920s as a solution to 'modernize' the languages in the 'backwards regions' of the Soviet Union (i.e., non-ethnically Russian and to some extent non-Slavic territories), a new system of Latinization of letters in other alphabets was instituted. The Latinization process took place in areas with large Muslim populations, including Uzbekistan. Examples of Latinization of alphabets can be found in Kalmyk children's school books such as the skazka (fairytale) The Three Little Pigs, which was written in Kalmyk language but in Latin characters. ${ }^{312}$ Later in the 1930s,

\footnotetext{
${ }^{310}$ Francine Hirsch, Empire of Nations: Ethnographic Knowledge and the Making of the Soviet Union (Ithaca: Cornell University Press), 9, 102.

${ }^{311}$ Hirsch, Empire of Nations, 9.

${ }^{312}$ NMRK, 143/2, Orculacn'Hasuta Baatr, Naxan Hurvn Tuhl (Moskva: Biskn Kyykdin Degtr Narhac, 1937).
} 
under Stalin's Russification policies which began in the 1932-post First Five Year Plan period, the Kalmyk language is transliterated into Cyrillic and the teaching of Russian language becomes more pervasive in children's institutions.

As a way to conceptualize its empire, Soviet leaders established a four-tier hierarchical structure for languages spoken throughout Soviet territory, where each language was categorized as falling into the A,B,C,D category. It ranged from A, which was reserved for nationalities that were not as defined territorially and lacked a script for their language to $\mathrm{D}$ which identified well-developed nationalities in terms of their culture and economics that had traditional scripts and defined territory. Kalmyk language fell into the $\mathrm{C}$ category, reserved for medium or large-sized monolingual nationalities, that used a traditional script and had a proletariat intelligentsia and bourgeoisie which live in compact groups or are territorially united." ${ }^{313}$ For groups that fell under the $\mathrm{C}$ category, the Bolsheviks intended to establish primary, secondary, and professional education as well as political literature in the native language. It noted that 'the language of the federation will be introduced no later than the third grade and continue into higher education. ${ }^{314}$ Soviet officials placed language, rather than population size and needs, as the primary factor in determining where higher concentration of literature would be produced. In terms of geographical labels, union republics were more respected by Moscow than autonomous republics. ${ }^{315}$ The Kalmyk ethnic group fell under the

\footnotetext{
${ }^{313}$ Leonore Grenoble, Language Policy in the Soviet Union (Dordrecht, Boston, and London: Kluwer Academic Press, 2003) 45.

${ }^{314}$ Grenoble, Language Policy, 46.

${ }^{315}$ These notions of evolutionary hierarchy in culture and language reflected their geographical identities. For example the separate administrative units were divided into three rankings beginning with Autonomous Oblast, which was reserved for smaller ethnic groups, followed by Autonomous Republics, which were
} 
Mongolian -ethnic branch which shared written a language similar to Turkic. While republics or autonomous oblasts were named or defined by a principle ethnic group, no one republic was monolingual. Although the Kalmyks did have their own written language known as Zayapandit, which closely resembled Sanskrit in form, the Soviets rejected, because it needed a "special script for the press." "316 According to one former early Soviet Kalmyk pedagogue, the reason for dismissing the Latin alphabet after a few years was Soviet feared that the alphabet would link Kalmyks to the West and thus fall under their influence. ${ }^{317}$ Lenore Grenoble's research on the Soviet Union's language policy supports both claims. In her study she explains how in 1924, the Bolsheviks switched the Kalmyk script into Latin under the guise that it was the 'will of the people', because the Kalmyk script was "inaccessible and inflexible and could not be adopted to the phonological changes in Kalmyk." ${ }^{318}$ The shift from Kalmyk in Latin characters to Cyrillic was justified as a necessity because children at school tended to confuse Cyrillic and Latin letters, and thus have a negative impact on their grammatical skills.

In order to 'modernize' the population, and take them out of the darkness that resulted from superstition and lack of education (as was made popular in propaganda), the Bolsheviks created literacy campaigns, such as likbez-- likvidatsiia bezgramotnosti (liquidation of illiteracy). Despite its attempts at eradicating illiteracy, the Bolsheviks

determined to have evolved from the Oblast status, and finally Union Republics which were also ethnically separate from the Union, but had their own Communist parities (ex - Ukraine, Uzbekistan). Kalmykia fell under Autonomous Oblast in the 1920s and gained Autonomous Republic status in 1935.

${ }^{316}$ Harvard Project, Schedule B-5, Case 21, p. 2.

${ }^{317}$ Harvard Project, Schedule B-5, Case 21, p. 2.

${ }^{318}$ Grenoble, Language Policy, 50. 
faced several problems, especially due to the fact that many ethnic groups did not identify themselves with language, but with religion or geography.

\section{OUT OF THE DARKNESS: LITERACY GOALS AND PROGRAMS IN SOVIET}

\section{OFFICIAL CULTURE}

"For to come out of the middle of the deep dark night, in order to brighten the path at a distance, we need a powerful source of light. The Kalmyk peoples are without light, are blind at night, and the dawn is still far away." Viktor Porokh ${ }^{319}$

Inspector and founder of the Kalmyk Autonomous Oblast school system Victor Porokh viewed literacy and education as key to lead Kalmyk peoples onto the road of modernity and illuminate their future. According to Igal Halfin, bringing its population from darkness to light was a common concept in Russian Marxist thought that related to class consciousness and the creation of the New Man, through eschatology—or the linear conception of time that saved man from 'the darkness of capitalism toward salvation in a classless society ... to the bright light of communism.. ${ }^{320}$ During the early Revolutionary years in the Kalmyk Oblast, Soviet officers and personnel such as Porokh held optimistic views as to how to enlighten Kalmyk children, raising and educating them with new Soviet traditions in tandem with their native ones. The Political Education Department (POLIPROSVET) resolved this issue by allowing general education to be taught in the native language. As seen in state propaganda journals including Komsomol'skaia Pravda, the POLIPROSVET along with the Kalmyk Department of People's Education

\footnotetext{
${ }^{319}$ NMRK, N 2124/ 44 d. 21, p. 1.

${ }^{320}$ Igal Halfin, From Darkness to Light: Class Consciousness, and Salvation in Revolutionary Russia (Pittsburgh: University of Pittsburgh Press, 2000), 1-2.
} 
(KONO) focused on the eradication of illiteracy as the main goal - especially in an area where literacy was "all of 2-3\%." 321

The trope of light and enlightenment that was prevalent in the context of space, continued with literacy as well as with culture and technology, including with the innovation of the cinema. The children, according to Porokh, needed "to be able to read with more light, and a new cinematic library - there was no access to these lighting apparati," and believed the growth of schools was by popular demand. ${ }^{322} \mathrm{He}$ added that $\mathrm{K}$ ONO worked carefully in the ulus (district) to build and organize schools, children's colonies, and children's homes. He emphasized that the introduction of Kalmyk children's first year studies of history would be taught in their native language ${ }^{323}$

Yet, for Soviet officials and Soviet society, the key to civility and modernity was the mastery of Russian language. For the next twenty years, the Department of People's Education (ONO) and Kalmyk division of ONO would develop programs, literature, textbooks and pedagogical methods to best introduce Russian language to Kalmyk peoples, just as Moscow schools had done for their pupils. These programs were not seamless and were fraught with contradictions and to a certain extent met with challenges from both teachers and students. At around the same time, similar problems arose in Russian schools in the capital. During the introductory stages of the of Kalmyk education system, Soviet pedagogical specialists developed the Russian language Program for the first 6 years of study. The main goal of the program was to research or understand the

\footnotetext{
${ }^{321}$ NMRK, N 2124/ 44 d. 21, p. 1.

${ }^{322}$ NMRK, N 2124/ 44 d. 21, p. 1.

${ }^{323}$ NMRK N 2174/ 48 p. 4.
} 
Kalmyk child's psyche. This goal was also shared by other pedologists and educators across the Soviet Union, which invested resources in understanding children's psychology in order to identify and cultivate traits needed for the new society. New emphasis was placed on anthropological studies of Kalmyk children and their daily lives and combining instruction both written work and the arts. "The teaching is not the same when one teacher manages the school colony. The teacher needs to take interest in children's lives, together with hand work, and children's art... and children's games.”324 Therefore, pedagogues emphasized the importance of understanding not only Kalmyk culture, but children's mentality, development, and their everyday lives.

The optimistic view of developing Soviet education for Kalmyk children continued well into the 1920s. During the mid-20s under the New Economic Policy, the Metodicheskoe bureau pri Kalmyitskom Oblastom Otdele Narodnogo Obrazovaniia published, as it did every year an instructional letter for teachers. In the 1925 edition, published eight years after the October Revolution, the author I. S. Konovalov began the instruction with a solemn anti-nostalgic anecdote of Kalmyk children's preRevolutionary education: "Before the October revolution, Kalmyk children had to study in 'alien' Russian' schools, the Russian language [was] foreign to them not answering questions nor being interesting for children." Konovalov used the term russikikatorskaia politika tsarskoi vlasti (Russification politics of the Imperial power) to define tsarist Russia's imperial motives and the repression of its subjects. He continued to describe how the tsarist imperial system "tore all native life away, crippling intellectual development of our children. And the result was well-known: Kalmyk people did not

${ }^{324}$ NMRK N 2174/ 48, p. 4. 
have one book in their own language, resulting in the pre-revolutionary illiteracy rate as 95\%. Soviet power gives us (Kalmyks) our own native national school.,325

Despite his optimism and goal to continue Soviet nationality schools-- with emphasis in native language study - Konovalov expressed the need for Kalmyk children to learn Russian simultaneously: "In the USSR there are Autonomous republics in which only Russian language is studied in the beginning of the second grade. And this is correct." However, he also noted that in the Kalmyk context, it was also unrealistic to pursue such a strict Russian-only policy. He explained how Kalmyk education needed to emphasize more "teaching practical realistic demands of life" in order for Kalmyk children "like other republics of national minorities" obtain more opportunities. He concluded by urging that it is more appropriate begin to teach Russian language in nationality schools in the first year, instead of the second year of study, showing urgency to introduce Russian language study earlier than prescribed in the nationalities law. ${ }^{326}$ In sum, Kalmyk academic programs for the first six years of study derived from four main strands:

1. Native language

2. Russian language

3. Natural sciences

4. Mathematics. ${ }^{327}$

\footnotetext{
${ }^{325}$ I. S. Konovalov, Instruktivnoe pismo No $5: k$ uchiteliam -Kalmyikam o provedenii natsionalizatsii shkolyi 1-iy stupeni v Avtonomnoi Kalmyitskoi Oblasti, s 1925-26 uch g. (Astrakhan: Tipografiia Kalm. TsIK, 1925), 4.

${ }^{326}$ Konovalov, Instruktivnoe Pismo No.5, p. 14.

${ }^{326}$ NMRK, V. Porokh, “Doklad: Zavedivaiushchego ONO,” p. 14.

${ }^{327}$ NMRK, V. Porokh, “Doklad: Zavedivaiushchego ONO,” p. 1.
} 
With Native language as the primary subject, the goals of the KONO were to introduce Russian language and culture in conjunction with Kalmyk. Pedagogues suggested that teachers should assign activities from the book Kalmyk and Russian children's Games, as early as the first term in the school year and to familiarize themselves with special methods in teaching Russian language in Kalmyk schools (Osonovii metodiki russkogo iazika v Kalmytskoi shkole). Therefore, officials wanted children to maintain their ethnic roots while learning Russian values and language, through literature. In doing so, Soviet officials had a more benign approach to the Soviet civility process by keeping children's interests and needs in mind. They did so by creating new games and understanding notions of childhood to facilitate Russian language acquisition, while adhering to the state-wide nationalities policy.

While the local officials made the effort to promote native language education, there is evidence of the Sovietization of the Kalmyk language. As noted in the list of a Kalmyk children's book repository, the majority of the books intended for children to conceptualize their history as well as their place within Russian and Soviet geography and culture. A sample of the books on the list reveal a bilingual selection with an emphasis on geography, mostly in Russian language, and books on native culture: Istoria Rossii (History of Russia), Istoria tartar (Tartar History), Istoria Turk (Turk history), Geografia Rossii (Geography of Russia), Kratkaia Geografia (Brief Geography), Uchites' Geografiia (Learn Geography). While learning intra and international history and geography, students were also required to familiarize themselves with native history reading books such as Budda (The Buddha), Istoria Astrakhan (History of Astrakhan). ${ }^{328}$

${ }^{328}$ NARK, f. R-25, o. 1, d. 114, “Katalog,” p. 298. 
However, not all books were solely in Russian. Well into the 1930s, the Xal'Mg (Kalmyk) publishing company continued to distribute textbooks in Kalmyk, though mostly with Latin characters, which included subjects in Geometry, Geography, and Literature. Not too dissimilar from their Kalmyk counterparts, Moscow schools relied on cultural-specific literature to assign in Russian language courses. An example of course readings in order included The Unification of the Kingdom of Sviatoslav, First Peasant War in the Russian State for third-year students in the Komitetsko raion, while fourthyear students read How they oppressed the peasant in the Russian State during the XV century. $^{329}$

Figure 9: Example of Kalmyk Language Geography Textbook Printed in Latin. ${ }^{330}$

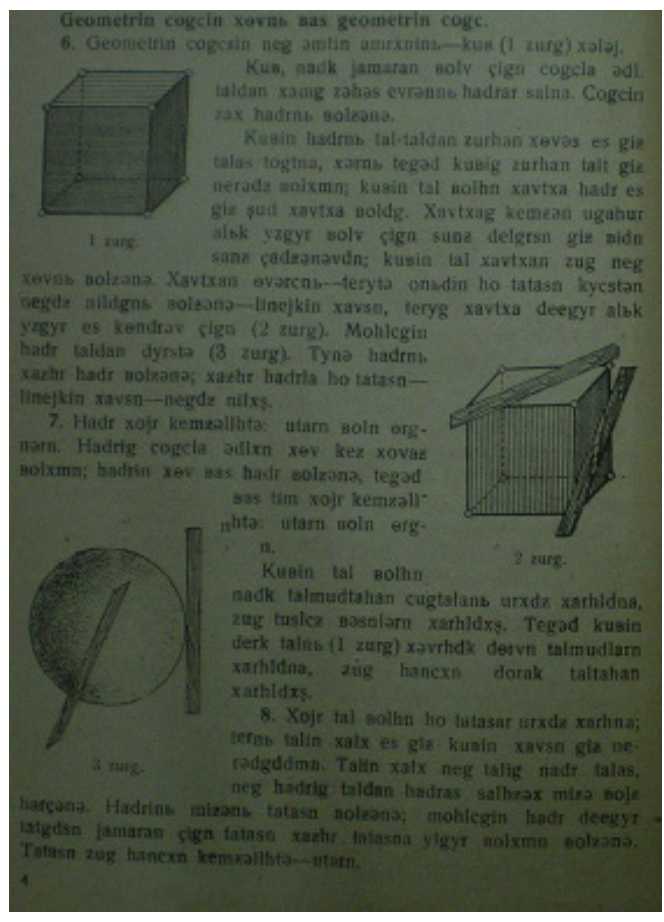

\footnotetext{
${ }^{329}$ TsAGM, f. R -528, o. 1, d. 522, "Botchery MOSGOR ONO o rabote po russkomu iazyku."

${ }^{330}$ NMRK, N- 9681, Geometrin: Tuskar Medylg (Elista: Xal'Mg TANCIN DEGTR NARNAS, 1934).
} 
Figure 10: Example of Kalmyk Language Literary Textbook Printed in Cyrillic. ${ }^{331}$

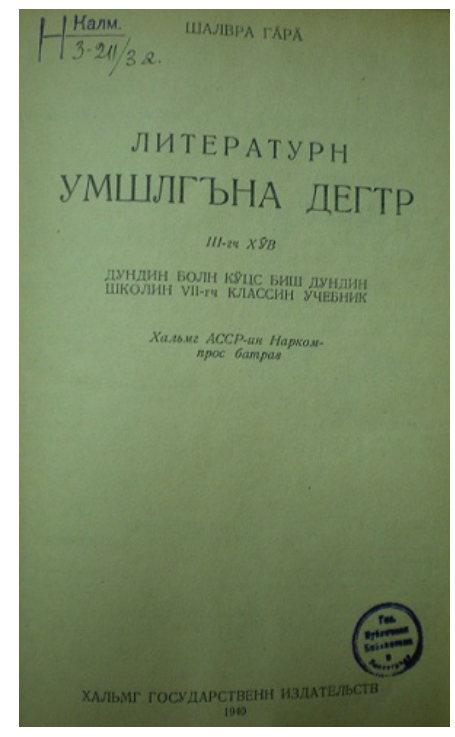

In one interview, a Kalmyk male expressed how as a schoolboy in the 1920s he wrote and learned in Russian. He noted his frustration with the absence of the Kalmyk alphabet and having to write Kalmyk with Cyrillic characters, only to convert to Latin in the late 1920s. ${ }^{332}$ He also complained that "Russian pupils did not learn the Kalmyk language [but that] Kalmyk children had to learn Russian." 333 The individual's testimony of his early schooldays illustrates the contradictions of the Soviet language policy as well as the expectations of the population. The official policy supported native language instruction, but Russian teachers often demanded that non-Russian children (and teachers) use Russian, even though they themselves did not make the effort to learn their pupil's

\footnotetext{
${ }^{331}$ NMRK, INV. No 865 TS 1940 G . Ant. No 808 Literaturn Umshelg'na Degtr (Elista: Xal'mg Gosizdat, 1940).

${ }^{332}$ Harvard Project, Schedule B-5, Case 15, p. 15.

${ }^{333}$ Harvard Project, Schedule B-5, Case 15, p. 8.
} 
language, thus creating a situation where Russian teachers ignored or challenged Soviet language policy. ${ }^{334}$

As exemplified by historians of Soviet history including Charles E. Clark, the early Bolsheviks invested in literacy campaigns throughout Russia and particularly geared them towards the peasantry. In his study, Clark emphasizes how the Bolsheviks wanted to eradicate Russia's "Otherness" by making the peasantry more cultured and for the population to reflect the world view and represent the new ruling body through literacy. ${ }^{335}$ Local Moscow oblast and city schools shared the same optimism, goals, and values as Kalmyk pedagogues in their 'fight against illiteracy.' As early as spring 1920 the Moscow People's Department of Education (MONO) declared the eradication of illiteracy for children of 'school age' (as opposed to preschool) within four months. ${ }^{336}$ By 1934, MONO declared its 5 million rubles investment along with the 186 million rubles from Mossoviet. In this sense, rather than looking at the past to compare its improved conditions for children's literacy and access to education, MONO after the First-Five Year Plan looked at its success in children's education as another of Stalin's triumphs that exceeded contemporary Western nations' social, economic and educational conditions: “...this is why the Soviet Union is much more successful than Old Russia,

\footnotetext{
${ }^{334}$ See works of Tom Ewing.

${ }^{335}$ Charles E. Clark, Uprooting Otherness: The Literacy Campaign in NEP-Era Russia (Selinsgrove: Susquehanna University Press, 2000), 17. For more on the relationship between Imperial Russian or Soviet society and literacy, please see, Jeffrey Brooks, When Russia Learned to Read: Literacy and Popular Literature, 1861-1917 (Princeton: Princeton University Press, 1985); Jeffrey Brooks, Thank You, Comrade Stalin!: Soviet Public Culture From Revolution to Cold War (Princeton: Princeton University Press, 2000); Catriona Kelly, Refining Russia: Advice Literature, Polite Culture, and Gender from Catherine to Yeltsin (Oxford: Oxford University Press, 2001).

${ }^{336}$ TsAMO, f. 6756, o. 1, d. 6, "Instruktsii polozheniia po organizatsii det/domov svedenia o rabote sotrudnikov," p 3.
} 
Europe, and America. Today, unlike before the world crisis, they can no longer boast about their populations' education... especially now with the decline of quality teachers." ${ }^{\text {337 }}$ Throughout the 1930 s, MONO continued its avid campaigning against illiteracy for children, extending its focus on disenfranchised children such as those housed in children's homes and colonies: "they should have the same opportunity to acquire literacy as if they lived with a family." By the 1930s, unlike the 1920s, the Bolshevik pedagogues viewed the family and everyday home life as essential to gaining access to literacy and becoming more successful Soviet men and women: "Literacy gives [the children] the opportunity to prepare for lessons, acquire academic learning, and opportunity to gain knowledge",338

In addition to local Kalmyk and Moscow goals, there were overall State-lead goals and programs that were designed to aid in acquiring $100 \%$ literacy for children and youths. The most notable aspect of the literacy campaign was the holiday, Den' Knigi (Book Day), which declared that "no city in the Soviet Union should be without a book." 339 The purpose of Den' Knigi as reported in the September 1928 issue of Komsomol'skaia Pravda, was not only to celebrate literacy but to also emphasize collectivity in reading in the sense that the act of reading and acquisition of knowledge are shared activities, and were key to acquiring Soviet citizenship.

\footnotetext{
${ }^{337}$ TsAGM, f. R-528, o. 1, d. 130, "Doklad zaveduiushchego MOSGOR ONO Moskovskaia Shkola”, p. 1.

${ }^{338}$ TsAGM, f. R-528, o. 1 d. 416, "Stenogramma Konferentsii rabotnikov detskikh domov, 1936." Doklad Tov. Kalinoi o poriadke detdomakh," p. 18.

339 “Den Knigi," Komsomol'skaia Pravda, September 2, 1928. Also see, "Prazdnik Sovetskoi Knigi, 10 Let Gosudarstvennogo Izdatel'stva: Knigi v Massii Molodozhi," Komsomol'skaia Pravda, May 21, 1929.
} 
Newspapers also focused on other parts of the Soviet empire and its achievements in bringing literacy to 'traditionally backwards' regions. The achievements of the literacy campaigns were highly publicized under Stalin during and especially after the First-Five Year Plan, as commonly found in this era's culture and official discourse. In one story featured in the propaganda journal USSR in Construction, there is a photo of a young Kazakh girl writing on the chalkboard in Roman letters. The caption under the photo boats "before the October Revolution: one newspaper, not a single theatre... two percent of literate Kazakhstan." According to the article, the Bolsheviks "triumphed" in Kazakhstan on its $15^{\text {th }}$ anniversary of being part of the Soviet Union, when it achieved in publishing "116 newspapers in Kazakh language, establishing 7000 elementary schools, 580 middle schools, with 754,000 pupils, 20 colleges and universities and ... 834 cinema houses. ${ }^{\prime 340}$ One example of a Den' Knigi celebration was reported in the 1929 Komsomol'skaia Pravda article that celebrated the growth of literacy in Tartar schools: "At the present time, you cannot find such an oblast of socialist establishment, look at how the youths work to help improve life. In the last year in the culture building of Tartar achieved significant success. Literacy grows and the number of schools are increasing. From 1920 - 1926 the literacy rate among the Tartars increased $15.5 \% . "{ }^{341}$ Other literacy-based programs included, "books for kopeks" as well as writing contests for children. In Kalmykia, the kul't armetai headed by older school students, were the primary force behind the movement to eradicate illiteracy for years to come. ${ }^{342}$

\footnotetext{
340 "The Fifteenth Anniversary of Kazakhstan," USSR in Construction, No 11, 1935.

341 “Molodezh' Tatary v Borbe,” Komsomol'skaia Pravda, June 1929, p. 6.

${ }^{342}$ Harvard Project, Schedule B, Case 23, p. 6.
} 


\section{LEARNING LANGUAGE THROUGH THE EVERYDAY AND THE MARCH} FORWARD IN SOVIET KALMYKIA AND MOSCOW

In 1922 (post-Civil War) inspector Porokh complained that "there were problems with children acquiring Russian language."343 "Representing the mixture of the most diverse ages from 7-15 years and these children did not know Russian speech not able to read or write." According to Porokh, one of the ways to remedy this problem was to break the students of school age into two groups. Despite his effort in segregating children to reduce student to teacher ratio, he found that children still struggled with Russian language acquisition in Children's Home No. 1 (Detdom No 1). He noted from the results of this experiment that Russian language instruction decreased and the children from the first group were only able to translate short sentences. He continued to explain that children were able to connect the meaning of the words by telling stories that they rehearsed. ${ }^{344}$ Beyond struggling with children's inability to acquire Russian language skills, inspectors in early Soviet Kalmykia complained about other post-Civil War problems, including banditry, disease and a decline of workers in children's institutions. $^{345}$

Problems with literacy were not limited to Russian language acquisition. Soviet officials in the immediate post-Civil War period struggled in finding native language instructors, especially as a result of teachers' illnesses and disease outbreak in the region. Inspector Porokh continued to lament on how schools in other parts of the Kalmyk oblast

\footnotetext{
${ }^{343}$ NARK, f. R-25, o. 1, d. 116 ,"Dokladyi Inspektorov,” p. 93.

${ }^{344}$ NARK, f. R-25, o. 1, d. 116 ,“Dokladyi Inspektorov,” p. 94.

${ }^{345}$ NARK, f. R-25, o. 1, d. 116 ,"Dokladyi Inspektorov,” p. 95.
} 
were ill-managed as a result of lack of teachers: "We are not even able to find for such schools teachers of native language. Therefore, the school does not have the ability to teach it." In this particular school, the resolution was to teach subjects, including Kalmyk history in Russian "by Russian teachers.",346

Table 4: Average Number of Hours Departmentalizing Kalmyk Education, $1923^{347}$

(Numbers represent hours spent on a weekly basis per subject).

Subject Group I Group II Group III Group IV

Native language $\quad 7 \quad 7-42$

$\begin{array}{lllll}\text { Russian Lang } & -- & -- & 6 & 6\end{array}$

$\begin{array}{lllll}\text { Mathematics } & 5 & 5 & 3 & 3\end{array}$

The mid -1920s were marked with a shift in the preoccupation of Soviet-style learning in Kalmyk schools. Pedagogues emphasized that teachers relate to children through their age as well as their byt or traditional routines or way of life. In his instructional letter to local teachers, inspector Konovalov advised teachers to switch course materials especially for first year studies in Kalmyk national schools. He called to fix the challenges of teaching Russian language in Kalmykia which he considered to be one of the most complicated republics school systems in teaching Russian. Konovalov urged instructors that the 1924-5 academic year required "the most extreme preparations"

\footnotetext{
${ }^{346}$ NARK, f. R-25, o. 1, d. 116 ,"Doklady Inspektorov,” p. 95.

${ }^{347}$ NARK, f. R-25, o. 1, d. 116 ,"Doklady Inspektorov,” p. 92.
} 
- noting the continued challenge that there were no Kalmyk teachers to teach native language, which was a State-based requirement in nationality schools. ${ }^{348}$

In order to improve the teaching of native and Russian languages for children, Konovalov proposed a special organization of nationality schools according to Oblast ONO regulations. He called for an integrated-school system taught both by Russian and Kalmyk teachers for children in the first and second years of school, with native language instruction. One of the most important pedagogical aspects of language acquisition that was shared by all Soviet officials and inspectors in Kalmykia was placing emphasis on children's conditions of life. Soviet officials would achieve their cultural language programs by ordering the appropriate school textbooks, in the native language that included themes and interesting for Kalmyk children and relatable to their byt, or everyday practices and routines. He also urged teachers to be sensitive to children's age group and stressed teachers to be enthusiastic in their lessons. Furthermore, Soviet pedagogues advised that academic material and course work should be current, familiar, and accessible to children, with emphasis on ensuring that any of the subjects should reflect the necessity of the work and duty of daily life. ${ }^{349}$

While acknowledging the need for understanding Kalmyk children's everyday life, and accessibility of native language in their studies, Konovalov stressed repeatedly the need for Russian language in Kalmyk schools so that the children would "not lag behind.” Again, the emphasis on Russian language study reveals how it would increasingly become the central focus of children's education, as part of the Soviet

\footnotetext{
${ }^{348}$ NMRK N 2174/ 25 .I. S. Konovalov, Instruktivnoe pismo No 5, 1.

${ }^{349}$ NMRK N 2174/ 25 .I. S. Konovalov, Instruktivnoe pismo No 5, 8.
} 
modernizing projects. Russian language, for Soviet officials, was more than a tool in the path towards revolutionary modernity. It was also seen as being more sophisticated and could only improve children's education since it had "a very rich pedagogical literary method in which allows facilitation of learning," and as a result allowed for the entire Soviet Union to achieve the "mass experience" of learning in the creation of new schools. $^{350}$

Like in the spheres of hygiene, space and nutrition, the modernization of children's education was characterized by the rise of professionalization or specialization of teachers in the local region. As early as the mid-1920s, with the introduction of the New Economic Policy, Russian gave way to the primary focus or method of learning in schools, emphasizing its superiority in all aspects of upbringing. Pedagogues such as Konovalov urged teachers to master the methodologies in the State-recommended Russian language books for Kalmyk teachers, because without these, "it would be impossible to work in contemporary Soviet schools," especially since the work of Kalmyk teachers was growing to increase Russian language study. Konovalov reemphasized that the learning of Russian language was more beneficial to the child and noted that the native language books are never as pedagogically efficient as Russian ones, in terms of language instruction. Soviet regional pedagogues were ambivalent even in their own language acquisition policies. On the one hand, they told teachers to cater to students' byt or their everyday routines and familiarity with native culture and language.

${ }^{350}$ NMRK N 2174/ 25 .I. S. Konovalov, Instruktivnoe pismo No 5, 9. 
On the other, pedagogues emphasized the importance and superiority of Russian language as critical to a child's overall success. ${ }^{351}$

The importance of teaching Russian in an integrated system became more evident with pedagogues' advice and guidelines for students to follow in their nationality schools. Pupils in the first year of school were not exposed to Russian study, but learned their subjects in the native language. It was only when children reached their second year that teachers introduced Russian while integrating native language in their studies. Afterwards, in the $3^{\text {rd }}$ and $4^{\text {th }}$ years, Russian would become the predominant language taught in the classroom and generally taught by Russian teachers. Again, emphasis was placed on children's accessibility to the material especially with age -appropriate lessons. As listed in the Instructional letter to teachers, in their language classes, children learned Russian conversational speech, writing, and reading Russian books with easy, familiar subjects to make it more appealing to them. ${ }^{352}$ Thus, the integration school system was based on the rationale of children's age and their cognitive development. The idea of not introducing Russian until the second year was to ease the first year's student transition to Soviet education. One former Kalmyk student describing his elementary school experience in 1931 noted that it was only after completing the first four years of narodnaia shkola (people's school) would children begin to learn Russian and other subjects including math and history. "All those are taught in Russian, but for those who didn't understand the material, it would be translated into Kalmyk by the teacher." 353

\footnotetext{
${ }^{351}$ NMRK N 2174/ 25 .I. S. Konovalov, Instruktivnoe pismo No 5, 9.

${ }^{352}$ NMRK N 2174/ 25 .I. S. Konovalov, Instruktivnoe pismo No 5, 14.

${ }^{353}$ Harvard Project, Schedule B, Case 23, p. 5.
} 
He also pointed out the ways in which schools were segregated up until the $5^{\text {th }}$ year in which Kalmyk students would not attend the same schools as their Russian and Ukrainian neighbors until the $5^{\text {th }}$ year. Although this may have been the case, some Russian students managed to learn Kalmyk language. The same interviewee admitted one case in which one Russian student "knew better Kalmyk" and the Kalmyk epic Dzhangur than he did. ${ }^{354}$ The fact that the schools' programs were designed to emphasize Russian language increasingly over the course of a child's educational career made it clear that Russian would become the more important language, significant to Soviet modernity, and children's accessibility to state jobs, as it was a marker of their Soviet civility. 1930s KALMYKIA AND THE CULTURE OF CRITCISM

While in the 1920s inspectors identified shortages of teachers and student participation in the classroom, in the 1930s, inspectors' language or complaints in their reports seemed to turn towards suspicion and sabotage. The optimism of the establishment of nationality schools in the 1920s and learning, integrating Russian instruction with Kalmyk language gave way to an era of pessimism and blame. While the learning of native language in school was practiced in conjunction with the nationalities program, over time especially in this decade, Russian was more prominent in the classroom. It became the lingua franca and an important element of the mass educational experience, and a key to inclusion of Soviet civility. If in the early 1920 s the nationalities schools in Kalmykia were struggling or failing, inspectors located the source of the problem to material causes, such as insufficient funds, teachers or classroom resources. In the 1930s, however, the failure of children's progress was addressed to the teachers

\footnotetext{
${ }^{354}$ Harvard Project, Schedule B, Case 23, p. 8.
} 
themselves, and through some evidence in the sources, placed blamed on the students themselves. In fact, inspectors' reports especially from the 1938-39 school year reveal a total failure on the Kalmyk education system. These discourses of suspicion and blame were all reflective of the climate of the era of Stalin's Terror and the coming of the Second World War.

As Larry Holmes shows in his study Grand Theatre, the culture of criticism was a Soviet-wide phenomenon that lasted between $1931-41 .{ }^{355} \mathrm{He}$ also shows this in his study of Kirov School No. 9, which focuses on the school director Sergei Nikolaevich Kornev's initial successes and then failures in running School No. 9. For Kornaev, 1939 marked the demise of his school's prestige when inspectors criticized his inability to maintain $100 \%$ of attendance and failure to maintain interest in older students to join the Komsomol. $^{356}$

While the Kirov case shows dwindling prestige of the school, in Kalmykia, inspectors recorded an overall decline according to students' grade levels and subjects in the first years of the 1930s. According to the table below, native language scores were strong in the first two years of study, while students consistently failed in Russian language since its introductory year second grade students.

\footnotetext{
${ }^{355}$ Larry E. Holmes, Grand Theatre: Regional Governance in Stalin's Russia, 1931-1941 (Lanham: Lexington Books, 2009).

${ }^{356}$ Larry E. Holmes, Kirov's School No. 9: Power, Privilege, and Excellence in the Provinces, 1933-1945 (Kirov: Self-published, 2008), 69-70. For more on Soviet education please see Larry E. Holmes, Stalin's School: Moscow's Model School no. 25, 1931-1937 (Pittsburgh: University of Pittsburgh Press, 1999), which would be the urban counterpart to his study on Kirov School No. 9.
} 


\begin{tabular}{lllll}
\hline \multicolumn{5}{c}{ Table 5: Average Scores According to Age Group in Privolga School, 1931-1932 } \\
\multicolumn{1}{c}{ Subject } & I & II & III & IV \\
Native Language & 85 & 80 & 54 & 47 \\
Russian & - & 50 & 54 & 47 \\
Math & 93 & 89 & 60 & 53 \\
Social Sciences & 100 & 100 & 70 & 60 \\
Geography & --- & --- & 47 & 45 \\
Work & 80 & 78 & 57 & 56 \\
Upbringing & 95 & 95 & 50 & 50 \\
Drawing & 87 & 88 & 40 & 40 \\
& & & & \\
\hline
\end{tabular}

The table above reveals the combined scores of students in the first year through fourth of the Privolgovskaia school. It shows a general trend of students in the earlier grades excelling in subjects from native language, social sciences and socialist upbringing, while the older students consistently scored low marks in the same subjects and especially in Russian language. There are however, other explanations for these results including the fact that the third and fourth grade students would have attended the first and second grade during a period of extreme turmoil in Soviet state and society. Also, students of the older grades included youths who were required to repeat the same grade.

${ }^{357}$ NARK, f. R-95, o. 1, d. 37, "Protokol uch proizvodetvennogo sovetsshia shkole," p. 86. 
According to the local school officials, the older students' lack of care or participation in class is what caused these scores. Here, for the first time in the sources, the officials are specifically blaming the children for the lack of progress in their grades. Furthermore, the inspectors were quick to blame these children's parents for their lack of progress, since, according to them, their parents failed in providing the necessary provisions or care from early childhood to help these 'older' children to learn or instill work ethic in them. ${ }^{358}$ In addition to parents not helping, inspectors pointed out the lack of materials or textbooks to study Russian language in nationality schools. Therefore, according to inspectors, the combined lack of attendance and participation of students and parents and texts, created an undesirable atmosphere that inhibited Soviet projects in providing proper education and lessons of civility for children, in a region that was considered to desperately need it. The older students' grades are telling especially in the sense that they are published at the end of the First-Five Year Plan, a period in which, as discussed above, the Soviet projects of state-wide literacy programs aimed at adults were said to have been achieving extremely rapid paces throughout the Soviet Union.

During the late 1930s, the blame shifts from students to other causes, including teachers, the institution, and textbooks. As Tom Ewing discusses in his work on teachers in Stalinism, this is not surprising. Blaming teachers for students' failures was an extension of the Terror, and teachers in Kalmyk nationality schools were not exempt from this culture of blame. ${ }^{359}$ According to an inspector's report on the 1938-39 school

\footnotetext{
${ }^{358}$ NARK, f. R-95, o. 1, d. 37, "Protokol uch proizvodetvennogo sovetskoi shkole," p. 83.

${ }^{359}$ Tom Ewing, "Restoring Teachers Their Rights: Soviet Education and the 1936 Denunciation of Pedagogy," in History of Education Quarterly 41, no. 4 (Winter 2001): 471-93.
} 
year in the Kalmyk ASSR, all schools failed in providing adequate education for students. In the Privolzhskoi ulus, the inspector noted that "the schools failed to eradicate sabotage work performed by the enemies who managed their way into leadership positions of the NK RSFSR (NARKOMPROS) and K ONO," which resulted in their closure in the first half of the academic year. ${ }^{360}$

The inspector reported how in their district "no teachers have accomplished 100\% performance from their students," and rather tend to perform poorly in subjects. One of the main examples he gives is from the Kanukovska school, where in the first half of the school year the average performance of the students if $79.6 \%$, "where in the senior classes the majority of students 359 people have a grade point average of $77.6 \%$." As most inspectors' reports particularly focused on, abysmal Russian language scores were the litmus test for absolute failure in nationality schools, which becomes increasingly noted in the 1930s:

"Especially unsatisfactory (neudovletvoritel'no) as in the case with Russian language... In Nitsianskaia Elementary School the children are dictating 50 words (in the first class) and make about 10-44 mistakes per lesson, thus scoring $6.25 \%$ on average.”361

The report continues to explain causes of low literacy among Kalmyk students in Russian language. As noted in previous reports, the schools and KONO repeatedly failed to provide Russian Language textbooks for Kalmyk children's classes. In addition, it claims the absence of a long-time a Russian-language program that was mandated by the Narkompros division of the Kalmyk ASSR. The problem with course material was not

\footnotetext{
${ }^{360}$ NARK, f. R-92, o. 2, d. 10, “Svedenie Grivesskogo," p. 5.

${ }^{361}$ NARK, f. R-92, o. 2, d. 10, p. 5.
} 
only the lack or unavailability of books, but also those that were available, as in the Erkhinevoskaia region, were erroneous and too old, which not only includes Russian language books, but native language ones as well. The report, published in 1939, recorded that the latest available editions of language textbooks were from 1933. One former Kalmyk teacher reported that there was no one available to write textbooks in Kalmyk language for school children in the 1930s. ${ }^{362}$

In addition to unsuitable texts, and ill-prepared core curriculum for language acquisition, inspectors lambasted teachers for their ineptitude in teaching Russian language. One report states that "in every elementary school the teaching of Russian language misleads Kalmyk students." ${ }^{, 363}$ The inspector provided a concrete example such as Nitsianskaia Elementary School, where during Russian Language class the teacher wrote on the board the word 'Kripich' instead of the word 'kirpich'(brick). "One may see a countless number of examples, revealing illiteracy of teachers of Russian language." Therefore, the inspector accused Narkompros- K ASSR division for its complacency in not removing these teachers, while attacking them for teaching Russian history in Kalmyk (language). ${ }^{364}$ Again, inspectors noted other failures in teachers' instructional methods:

"Teachers mostly translate from Russian to Kalmyk language. From here teachers substitute in translation, but not many know history, for example, the teachers of Erkhnievskaia school (...) refused to present history with unknown motives [which

\footnotetext{
${ }^{362}$ Harvard Project, Schedule B-5, Case 15, p. 2.

${ }^{363}$ NARK, f. R-92, o. 2, d. 10, p. 5.

${ }^{364}$ NARK, f. R-92, o. 2, d. 10, p. 6.
} 
are] too abstract [and have] no political agenda. Also teachers in the first half year did not conduct even one lesson about history." 365

As evident in the school inspector reports in the Kalmyk region, children's inaccessibility to learn Russian and Russian history properly was seen as an overall failure in these children's upbringing. It increasingly seemed that a primary factor to achieve Soviet civility and the proper childhood required Russian language acquisition and history. The local inspectors regarded teachers' and students' absences with suspicion or sabotage. The lack of proper educational tools such as current language textbooks were seen as evidence of continued stagnation in a region that local officials worked to modernize with the rest of the Soviet Union and in particular, Moscow. When compared to their Tartar counterparts also schooled in the Astrakhan region, Kalmyk children in the late 1930s were still seen as lagging behind.

Failures in the teaching of languages through the integration school systems in early Soviet Kalmykia provide an understanding of the Bolsheviks' conceptualization of the proper Soviet childhood and education for non-ethnically Russian children. Based on all the factors discussed above, with the lack of personnel and materials for learning resulting in low progress in language acquisition, local officials saw this as hurting the children, keeping them in the dark. One former Kalmyk pedagogue described his experiences as a teacher during the Terror and during the campaign for $100 \%$ successful teaching which he defined as "Soviet pedagogy" in which "all students must learn because the idea that only some students should learn was regarded as ...bourgeois

\footnotetext{
${ }^{365}$ NARK, f. R-92, o. 2, d. 10, p. 5.
} 
theory." ${ }^{366}$ Understanding the reality in that not all pupils could learn the same he "became very disturbed and could not eat...I suffered terribly and my colleagues also became ill because they feared that they would be accused of wrecking." ${ }^{367}$ Yet, as Larry Holmes and Tom Ewing show in their studies, the culture of criticism was far from being an isolated event in the Kalmyk Oblast. Inspectors' reports throughout the Soviet Union focused on common delinquencies on the parts of teachers and students in their failures to achieve soviet standards of schooling, thus proving that the culture of criticism was formulaic in its prose and statements. ${ }^{368}$ As the following section shows, the case of Moscow was no exception to this culture of criticism that dominated official discourse in the late 1930s.

\section{THE MOSCOW CASE}

Although the capital, which was supposedly endowed with major resources, Moscow schools and its education system was not exempt from institutional challenges. Like their Kalmyk counterparts, Moscow schools and orphanages had low class attendance rates. In 1924, Moscow inspectors recorded low attendance in schools and an insufficient staff to train literacy for children older than preschool age. Also like Kalmyk schools, and perhaps even more so, Russian language was a primary subject with only Arithmetic equaling in the number of hours studied in class. ${ }^{369}$ Russian language instruction for $4^{\text {th }}$

\footnotetext{
${ }^{366}$ Harvard Project, Schedule B-5, Case 15, p. 2.

${ }^{367}$ Harvard Project, Schedule B-5, Case 15, p. 2.

${ }^{368}$ Holmes, Kirov School no. 9, 71, 77. Here, I am specifically referring to Holmes's discussion of inspectors' reports criticizing teachers for relying on textbooks "rather than the syllabus and could not make history interesting" as well as reports in 1940, where teachers defended themselves by blaming textbook shortages and students' laziness for the failure to meet state standards of education.

369 TsAMO, f. 6764, o. 1, d. 8, "Smeta na reshonii detskogo doma," p. 79.
} 
year students in Moscow schools included 2 hours of writing work, 1 hour Russian language dictation, and 4 hours of listening lessons, which, in fact, exceeded the amount of hours of Russian study than students in Kalmykia spent studying.

\section{Despite Moscow Otdel Narodnogo Obrazovanie (Moscow Department of} People's Education/ M ONO's) goals to eradicate illiteracy among children, the Oblast schools continued to struggle with Moscow children learning and acquiring proper language instruction. In the late 1920s, reports published scores and expressed inspectors' frustrations not too dissimilar from inspectors' notes in Kalmykia. Unlike Kalmyk schools, however, Moscow meeting notes stressed the importance of parental involvement in children's education. M ONO officials urged parents to take interest in their children's learning and review children's mistakes and discuss why they make them. $^{370}$

Despite the long hours spent on language instruction both at home and school, Moscow students' Russian language scores remained low. The reports show how students at certain schools in the district scored on average $30 \%$ in language instruction. M ONO officials reacted by urging teachers "to take concrete measures in order to fix these unsuccessful causes." They demanded teachers to keep students behind until they master the material learned in the classrooms and even learn to "correct errors among themselves." 371 Inspectors noted common spelling and grammatical errors in Moscow elementary schools. For example, one inspector complained how "often, children have

\footnotetext{
${ }^{370}$ TsAMO, f. 6764 , o. 1 , d. 8,7 .

${ }^{371}$ TsGM, f. 528, o. 1, d. 48, "Stenogramma soveshchanniia prepodavatelei russkogo iazika", p. 2.
} 
trouble with the word хищный (khishchnyi/ prey), they put a soft sign in place of a щ, and H. I consider that this is a fundamental [error]."372

Another report released in 1933 reveals the continual struggle of Moscow's children achieving literacy in Russian. According to the report, scores in syntax structure were as follows: out of 96 words, 35 students made 44 grammatical errors ${ }^{373}$ Inspectors observed children's inability to grasp the case endings for moi, moy, and svoi and attribute this to parents' lack of assistance or interest in children's education. They proposed that parents, in an everyday setting, need to "repeat these words in passing, make them habitual and then [the children] will understand." ${ }^{374}$ Again, local inspectors and pedagogues consciously attribute a child's success in Soviet citizen development linked to the everyday, habitual and in this case, everyday language practice both at home and at school. This shift in parental involvement in their child's education is also an extension of Stalin's Cultural Revolution and shift in family dynamics.

Even in the late 1930s, like in Kalmykia, Moscow District schools continued to struggle in having its students master Russian language and grammatical skills. One report released after the $1937-8$ school year states that students of the $5-7^{\text {th }}$ classes did not learn enough grammatical theory that would have been typically covered in the first quarter. As consistently seen in previous years and other Republics in the USSR, inspectors labeled textbooks as 'weak,' 'full of errors,' and tend to 'make mistakes in

\footnotetext{
372 TsGM, f. 528 , o. 1 , d. 48 , p. 4.

${ }^{373}$ TsAGM, f. R- 528, o. 1, d. 53, “GOR ONO Stenogrammii Sovieshchania po itogam proverohniikh ispytanyi po itogam, 1933,"p. 6.

${ }^{374}$ TsAGM, f. R- 528, o. 1, d. 53, p 7.
} 
sentence construction and mix up syntax analysis."375 Again, this is akin to the challenges schools in the Kalmyk region faced when their textbooks were 'erroneous' and outdated. The report provided concrete examples of students' consistent errors, including mixing up parts of speech or not understanding word composition as those in School No. 369, continued to make other mistakes in spelling and punctuation. ${ }^{376}$ In School No. 414 in the Pervomaia raion (district), the local inspector accused the school department of underreporting bad scores. He discovered the actual results of one of the classes in the schools that initially reported 7-8 plokho and ochen' plokho (bad and very bad) marks, in fact had 22 bad evaluation marks from 42 students, revealing 50\% student failure in Russian grammar. ${ }^{377}$

Other common grammatical errors continued to be reported. One inspector noted that it was rare to find a class in a school that had all the dnevniki (classroom journals) with the necessary records and protocols. In one classroom, he consistently found grammatical errors in children's dnevniki especially while note-taking. The following are a few of the common errors found in the $6^{\text {th }}$ class of School No. 411: гИометрия (gIometriia as opposed to gEometriia); Зделать (Zdelat' as opposed to Sdelat'), перИсказ (perIskaz as opposed to perEskaz), ФранцуЗкую революцю (FrantsuZkuiu Revolutsiiu as opposed to FrantsuZSkuiu Revolutsiiu).

In order to remedy the problems Moscow schools faced in teaching students proper Russian, local pedagogues and officials made several recommendations similar to

\footnotetext{
${ }^{375}$ TsAGM, f. R- 528, o. 1, d. 53, p 7.

${ }^{376}$ TsAGM, f. R-528, o. 1, d. 522, "Otcheti MOSGOR ONO o rabote po russkomu iaziku, literature, 1937$38, "$ p. 1.

${ }^{377}$ TsAGM, f. R-528, o. 1, d. 522, p. 2.
} 
those proposed in contemporary Kalmyk schools. One of the main recommendations was to have one main textbook publication for the entire school. Also, they suggested that in order for children to learn, teachers had to make the subject more accessible to them, especially by including visual aids. Local officials urged teachers to take a more active part on children's education by taking more time to supervise their readings as well as collect and check their dictation summaries.

Although some responsibility for the failures fell on parents and in cases even students, in the late 1930s, it was clear that teachers became the scapegoats for the stagnation and backwardness in children's education in Moscow (and Kalmyk) schools, particularly in Russian language courses. Inspectors provided names, schools, and class numbers of 'incompetent' teachers-using language that was reinforced by the culture of Terror. One report denounced the $7^{\text {th }}$ class teacher Comrade Yazikov of School No. 558. The inspector criticized him for being disorganized and by "filling the whole hour by passing random surveys around for the students," and for failing to even assign relevant homework. He noted that during class discussions, students would ask the same question as the previous student and as a result the answers were weak, unfruitful and "onedimensional." Another teacher, Comrade Matoriala of School No. 235, was also under scrutiny for not "thinking carefully while preparing for class." ${ }^{378}$ The report criticized her for disregarding proper sentence structure or parts of speech in new language lessons and especially for her own inability to teach the difference between short and long form adjectives.

${ }^{378}$ TsAGM, f. R-528, o. 1, d. 522, p. 4. 
In addition to their inability to teach or have their own mastery of Russian language, the other 'crimes' committed by teachers was teaching the material "dryly" in their lessons not even using a textbook. Inspectors attributed these causes as to why students failed to pay attention and become disruptive in the classroom, and lacked any semblance of ideal Soviet discipline. One "bad teacher," Netirovski, in School No. 535, was cited for never even lecturing to students and simply assigning class work: ${ }^{379}$

"In relation to the teaching methods given, unfortunately, we admit that in the lesson are missing any liveliness or enthusiasm, from the teacher and result in a lack of interest from the students. The teacher in most of the cases gives either colorless examples in lecture or politically harmful ones."

While it is clear that children were to have mastery of the Russian language and grammar as part of the Soviet education project, MONO officials also recommended that children learn more about history and the Soviet constitution as part of the process in Sovietizing the language and their culture. For example, students in the $3^{\text {rd }}$ and $4^{\text {th }}$ year were to study The short course on the history of the SSSR and especially study necessary Marxist-Lenin theory. According to one MONO official, in the beginning, history lessons were poorly organized, primarily because textbooks were given to teachers too late: 8-10 of September (The Soviet academic school year always began on September $1^{\text {st }}$ ). ${ }^{381}$ Just as intended for children in the peripheries, such as Kalmykia, Soviet education placed emphasis on mastery of the Russian language and history as the two most important

\footnotetext{
${ }^{379}$ TsAGM, f. R-528, o. 1, d. 522, p. 6.

${ }^{380}$ TsAGM, f. R-528, o. 1, d. 522, p. 3.

${ }^{381}$ TsAGM, f. R-528, o. 1, d. 522, p.11.
} 
subjects. They wanted children both ethnically Russian and non-Russian children to acquire the same mentalité - the Soviet one. In fact, one local official suggested that the teaching of history helped in the students" "political upbringing, [by helping] younger generations of patriots of their native builders of communist society, by knowing the history of their roots well - [which instills] emotion in children."382

\section{CONCLUSION}

The everyday instruction of Russian language, culture and history represented the modern, civility and the light towards Revolutionary progress. While initially, native language instruction was implemented in regional schools as part of the Soviet promise, sources reveal that there was constant 'suspicion' of 'undesirable and alien elements' teaching children, which became more pronounced in the late 1930s during the Terror. ${ }^{383}$ Over time, the Sovietization of ethnic minority children became part of the revolutionary path towards cultural refinement and historical consciousness.

Schools in both Kalmykia and Moscow struggled to implement strong literacy programs and maintain high levels of literacy and grammar among the students. Inspectors blamed these educational failures on lack of material- especially textbooksand most of all on the teachers who were not considered qualified and were labeled 'incompetent' to teach Russian language and Russian history to children, as evident in both case studies. However, as reported in the 1937 issue of Uchitel'skaia Gazeta, the

\footnotetext{
382 TsAGM, f. R-528, o. 1, d. 522, p. 12.

${ }^{383}$ TSAMO, f. 851, o. 1, d. 3 "Protokol Zadedannii" ; "Vragi obuchaiut nashikh," Komsomol'skaia Pravda, February 19, 1920.
} 
problem of lack of teaching materials and textbooks to help with child literacy was a state-wide issue. $^{384}$

The examination of language imperial policies towards language through the lens of the everyday allows us to see evidence of some forms of everyday challenges on the part of parents and students such as failing to attend class and failing to keep interest in children's studies. Students themselves in various regions probably did not take interest in the constant exposure of learning or mastering Russian and Russian history. Although a former Kalmyk teacher praised the Soviet system for expanding the Kalmyk school district to 40 schools, he also expressed his suspicions of Bolsheviks' motives: "The true plan was to raise the children in the Communist Spirit." ${ }^{385}$ He added: "The whole Soviet educational system produces narrow people as it is based on self-praise." ${ }^{386}$ The same teacher noted that although he joined the Komsomol when he was younger, he continued to practice Buddhism "The schools did not make non-believers out of Kalmyk students; I studied and I know this. The family plays an important role in this matter. Buddhism and Communism are incompatible. ${ }^{387}$

Post-Stalinist interviews of expatriates from Soviet (European) Russia reveal that children to a certain extent, "did not buy into the propaganda" and that Russian education was based on treachery and suspicion "that kills the soul" and tended to "alienate" the

\footnotetext{
384 “Knigi est', A detiam chitat' nechego" Uchitel'skaia Gazeta, October 11, 1937, p. 2.

${ }^{385}$ Harvard Project, Schedule B-5, Case 15, p. 3.

${ }^{386}$ Harvard Project, Schedule B-5, Case 15, p. 12.

${ }^{387}$ Harvard Project, Schedule B-5, Case 15, p. 3-4.
} 
family. ${ }^{388}$ Several interviewees admitted that as children in early Soviet Russia, they dismissed most of their assigned readings because they tended to be 'dull and boring', or preferred to read classics, such as the "wild west or Victor Hugo." 389 Some former students' testimonials confirmed that there was a lack of books in their schools, while others simply stated that did not bother with reading. If we can allow ourselves to take these testimonies as true, then these children to a certain extent were able to evade the everyday practice of reading and mastery of Russian language and culture. In other words, some children managed to escape or live outside of the constructed byt or everyday routine of the socialist state. Children born before or in the immediate stages of the Revolution may not have nostalgia for past (as the Bolsheviks intended), but also seemed not have affinity for the present. ${ }^{390}$ For Kalmyk children the same sentiments of disdain and mistrust were expressed, as will be explored further in the concluding chapter. Regardless of the nuances that existed in both sites, the early stages of lighting the Revolutionary path to modernity and enlightenment through child literacy and the everyday, the Soviet Union, in various regions tended to make the same amount of progress, slowly making its way out of the darkness of the tsarist past.

\footnotetext{
${ }^{388}$ Harvard Project, Schedule A, Case 138, p. 38; Harvard Project, Schedule A, Case 143, p. 5.

${ }^{389}$ Harvard Project, Schedule A, No. 455 ; Harvard Project, Schedule A, No 420; Harvard Project, Schedule A, No. 420 ; Harvard Project, Schedule A, No. 4134, p. 48.

${ }^{390}$ While I consider these interviews valid sources, I do not take their content at face value. The interviewees, while not completely rejecting the Soviet system, do tend to have a 'script' in their narratives, especially about schooling and reading. Some even admitted that in the end, the Soviet literacy program did achieve its purpose in helping them acquire literacy. For more on reading memoires in the Soviet Union, please see Jochen Hellbeck, Revolution on My Mind: Writing a Diary Under Stalin (Cambridge: Harvard University Press, 2006).
} 


\section{CHAPTER VI: BORDERLESS EMPIRE: SOVIET CHILDHOOD AND THE EVERYDAY IN THE GLOBAL CONTEXT}

Odessa 10 February 1938

Dear Parents,

In Russia we are really well because it is a country of the proletariat. We go to the theatres, movies, circus, the opera, which is the second best in Europe and third in the world, and it is beautiful. It has pieces of gold. And there are with us bands of comrades: a Russian (woman) and the other, a Spanish woman. They are so nice. We also go to school in which we study Russian and Spanish and we already know how to read some Russian and count in it... ${ }^{391}$ Your son, Serafin Gonzalez, Spanish Children's Home, No3.

While Stalin's nationalities campaign policies --especially those directed towards children --permeated throughout the empire, they were not confined within the Soviet borders. The case of the Spanish child refugees fleeing the Civil War between the socialist factions and Franco's fascist forces reveals that Stalin's happy childhood campaigns extended to other parts of the world. Like their Kalmyk and Muscovite counterparts, the everyday practices and transformations of space, education, food and even language instilled a sense of Soviet solidarity with the Spanish children and their Russo-Soviet neighbors. Just as this dissertation illustrated with Soviet Kalmykia, in Spanish refugee children's homes and camps, a fusion between Russo-Soviet and Spanish culture developed. Spanish children also ate Russian cuisine, learned Marxist thought, and studied Russian language, while practicing their own native Spanish, as stipulated in the nationalities policy.

\footnotetext{
${ }^{391}$ Carta de Serafin Gonzalez a su padres. Odessa 10 Febrero de 1938. AGC PS Santander, Serie "O" 51/8.
} 
The early Revolutionary everyday habits, practices, and routines tended to be in a sense socialist in content and Russian in form, rather than "nationality in form" -as the official declaration proclaimed. As my dissertation has shown in Kalmykia and Moscow, the creation of common spaces took on a Westernized form with the school and the classroom as the central point of Soviet character-building. Yet, these Westernized and rationalized spaces took on characteristics that became increasingly Russian in material culture that adorned the children's homes and classrooms such as the samovar in the Kalmyk children's stolovaia, and with the Russian language that dominated class lectures and readings.

The Soviet childhood experience was a complicated phenomenon because it was one dominating set of distinctive features which transcended upon children from various ethnic backgrounds, that had already established traditions from the Pre-revolutionary era.

As my dissertation has shown, in terms of modernizing the empire it was not just the "urban areas in euro Russia that came closest" to being "primed for the Stalin Revolution." ${ }^{392}$ Although the statement may be true for Soviet policies and programs directed towards adults, in the context of childhood, a different narrative of similarities among children across the empire emerges. With childhood, empire and everyday as its focus, my dissertation discovered a lateral relationship between the different ethnic regions of the Soviet Union, in terms of the development of modernizing features in children's institutions and policies, as opposed to a strictly top-down one. While my project has noted the similarities in the implementation of the childhood policies at the

${ }^{392}$ Michaels, Curative Powers, 46. 
local level, it also highlighted the discrepancies in them, mostly from the voices of the actors studied — whether Russian inspectors, or Kalmyk students. Some of the discrepancies depended on who was telling the story. One former Kalmyk teacher explained how "Russians who did not know the Kalmyks and who came to live among us often regarded us as backward, but this could not be done openly since it would have been contrary to an owed Soviet nationalities policy and against the law." ${ }^{393}$ Indeed, the Russian inspector in Kalmykia snubbed his nose at traditional Kalmyk practices. Yet, the older Spanish children in Russia, held similar attitudes towards Russians when they expressed disdain and repulsion of Russian everyday practices, including hygiene and dining. For example, in her letter to her parents in Spain, Mari Juli complained about the lack of running water and having to resort "washing ourselves like cats." Mari Juli was also disgusted by the "strange things they [the Russians] eat. You can't imagine the disillusionment with the authentic Russian salad." ${ }^{394}$

Cultural prejudices within the urban and rural populations are not surprising. Even with urban representatives working in the city such as inspectors in Moscow schools projected and acted out the state's notions of cultural superiority. In the case of Moscow schools, teachers, inspectors, or directors transmitted the state's disapproval of religious celebrations and created programs to deter them.

Kalmyk individuals recalling their childhoods under Lenin and Stalin, while not discrediting Russian culture, also revealed their disapproval of the Soviet government and

\footnotetext{
${ }^{393}$ Harvard Project, Schedule B-5, Case 15, p. 9.

${ }^{394}$ Carta de Mari Juli, auxiliario acopamiento de los niños del expedición de Bilbao escribe a su madre doña Maria Oyazabal, en los bajos Pyreness (Francia) 1937 in Enrique Zafra, Rosalia Crego, and Carmen Heredia, Los Niños espanoles evacuados a la URSS (Madrid: Ediciones de la Torre, 1989), 109.
} 
imagined traditions or culture constructed by the Bolsheviks such as the happy childhood campaign. In fact, in most of the interviews, expatriate Kalmyks expressed their antiSoviet sentiments and overtly blame the Bolsheviks for the destruction of Kalmyk culture. One former Kalmyk student noted:

"The Soviets did not save the Kalmyk people from destruction. This is a lie. It gave the youth a chance for education but the Soviets did suppress us and other people in a most tyrannical way...For 300 years we lived peacefully under Russian Tsarists. ${ }^{395}$ Another former student in Kalmykia echoed, "Under the old regime, there was freedom and people weren't suffering the pressure that they suffered under the Soviets." ${ }^{\prime 396}$ As seen in these two examples, what emerges from Kalmyk children and educators living under Lenin and Stalin is a script of blame or loss of childhood under the Soviet Union. It is these ideas and sentiments which current Kalmyk scholars draw from and emphasize in their own studies.

Despite this script of loss of a real or traditional childhood, both Kalmyk and Russian children exhibited disrespect for authority, whether defacing school property or praying in their homes -continued their prerevolutionary practices after the revolution, despite projects of increased Sovietization. ${ }^{397}$ This reveals the discrepancy between the Bolshevik vision of implementing the nationalities policies and Sovietizing the population through increased Russian language usage and atheism, which conflicted with the nationalities promise for at least the highly religious Buddhist population of Kalmyks.

\footnotetext{
${ }^{395}$ Harvard Project, Schedule B, Case 23, p. 19.

${ }^{396}$ Harvard Project, Schedule B, Case 15, p. 11.

${ }^{397}$ For more on these concepts please view John Scott, Weapons of the Weak and Sheila Fitzpatrick, Everyday Stalinism.
} 
While Spanish children's letters do not reveal any sense of disrespect towards Soviet power, letters from older children and youths exhibited disdain and disillusionment for the Soviet system as Mari Juli did, and especially testimonies written after the Terror and the Second World War. ${ }^{398}$

As evident in my study, but not surprising, the everyday practices of Sovietizing children worked best in Children's Homes, towards the besprizorniye, who were outside the influence of their parents and immediate family members. In the cases of urban Moscow, rural Kalmykia and even in the Spanish children's homes, the soviet childhood phenomenon, while full of economic and logistical challenges, in a sense, was successful in implementing its overall policies. With the everyday practices of space, hygiene, dress, eating, and language acquisition among children of disparate backgrounds, this study shows how the Soviets attempted to impose a pan-Soviet culture of childhood. This Marxist-Leninist Communist model of internationalism --as shown throughout the dissertation-- was applied in Eurasia (i.e., Kalmykia, Kazakhstan) and even as far as contemporary Western-Europe, as evident in the Spanish child staying at home during the war who wrote her letter to Russian children. In a plain paper stationary with a tri-color triangle and an exclamation-- Viva la URSS! -- Maria Luisa wrote:

To the children of Russia who sent us candy,

Russian brothers, we like to tell you that we very much enjoyed the candy that you so affectionately sent us. Thank you so much! Since there is this terrible war going on, we

${ }^{398}$ Testimonies from children who were evacuated to Russia during the Spanish Civil War express shocked when they realized the Soviet Union lacked basic needs that Communism promised to bring to everyone. Others also expressed fear and disillusionment when they observed the Communist Party's denunciations and arrest against foreigners, members of POUM (Spanish leftist faction), and Spanish teachers. For more please see Dorothy Legarreta, The Guernica Generation: Basque Refugee Children of the Spanish Civil War (Reno: University of Nevada Press, 1984). 
cannot remember that there are such sweets out there like the ones you sent us. To the fraternity and egalitarianism and to the progress thinking about Peace and the Victory of democracy! 399

Over time, Soviet influences would travel across the Atlantic, particularly to Cuba, where children after the 1959 revolution found themselves dressed with the iconic red scarf, white shirt, and blue shorts while they encountered Lenin's portrait in the classroom every day.

Soviet childhood imperial mechanisms did not equate to the eradication of national minority traditions that Marxism hoped to accomplish. As shown in my dissertation, everyday acts that may not have conformed to Soviet ideals, which either took place in the early Soviet classroom or nuclear family allowed for ethnic minorities to retain a semblance of their pre-Revolutionary cultural and religious practices. The Soviet nationalist legacies can be found today. In present-day Kalmykia, various elaborate Buddhist temples and architecture with Eastern accents adorn the capital city of Elista. Beyond the space and the place of nationalizing the territory, there is also a nationalist effort in the Republic to revive the Kalmyk language and teach traditional Kalmyk dances in child day cares. Despite the drive to revive pre-Revolutionary Kalmyk customs, children today continue reading Soviet children's classics such as Korney Chukovski's Mukha Tsokotukha (The Fly Tsokotukha) or sing Soviet children's tunes such as Kokodril Gena's birthday song.

My dissertation teaches us that even children of various ages --and ethnicities-whether in school hallway, streets of Moscow, the orphanage in Elista, the stolovaia or

\footnotetext{
${ }^{399}$ Carta de Maria Luisa Alvarez Villarga a Comrade Miguel Moran, Carta de una niña dirigida a los niños de rusia" Consejerio de Cultura, 18 March 1937 AGC Salamanca PS Santander Serie "CU” 2/23.
} 
the classroom, shared equal childhoods, experienced equal poverty and challenges, and managed to escape the overbearing policies of Soviet intervention, all while growing up 'Soviet.' 


\section{REFERENCES}

\section{RUSSIAN ARCHIVAL SOURCES}

\section{Tsentral'nii Arkhiv Goroda Moskvi (TsAGM)}

f. 528 Otdel Narodnogo Obrazovania, Ispolnitel'nogo Komiteta Moskovskogo Gorodskogo Soveta Deputatov Trudiashchikhsia/ Zapiski Igr Dlia Detei

Tsentral'nii Arkhiv Moskovskii Oblasti (TsAMO)

f. 581 Protokol Zadedannii

f. 587 Fotografii detskikh sadov

f. 2614 Protokol Zasedanie Prodovol'stvennoi Komissii trudovoi Kolonii I.M. Lenina

f. 6756 Instruktsii Polozheniia po organizatsi det/domov

f. 6764 Efimovskaia detskaia trudovaia koloniia perepisok

Natsional'noi Arkhiv Respubliki Kalmykia

f. R-25 Ministersvo Prosveshcheniia Kalmytskoi ASSR

f. R-92 Svedenie U ONO Kalmytskoi ASSR

f. $95 \mathrm{Ob}$ uluskom detskoe dome

Natsional'naia Muzei Respublika Kalmykia

N. 2124. Porokh, Viktor. "Doklad-zavedivaiushchego ONO"

N. 2174/25 Konovalov, I.S. Instruktivnoe pismo No. 5 k Uchiteliam-Kalmykam I provedenii nationalizatsii shkoli 1-y stupeni v Avtonomnoi Kalmytskoi Oblasti s 19251926 ych g. Astrakhan: Tipografiia Kalm. TsIK, 1925.

Baatr, Orculacn'Hasuta. Naxan Hurvn Tuhl. Moskva: Biskn Kyykdin Degtr Narhac, 1937.

Geograf (Elista: Xal'Mg Tancin Degtr Narnas, 1934.

Geometrin- Tuskar Medylg. Elista: Xal'Mg TANCIN DEGTR NARNAS, 1934.

Literaturn Umshelg'na Degtr Elista: Xal'mg Gosizdat, 1940. 


\section{SPANISH ARCHIVAL SOURCES}

Archivos Guerra Civil, Salamanca, Spain (AGC)

PS Santander, Serie “O”

PS Santander Serie "CU”

MEMOIRS, DIARIES AND INTERVIEWS

Duranty, Walter. I Write as I Please. (Simon and Schuster, 1935).

Harvard Project on the Soviet Social System, Russian Research Center Library and Widener Library, Harvard University.

Lugovskaya, Nina. The Diary of a Soviet Schoolgirl, 1932-1937. Chicago: Northwestern University Press, 2003).

Saranin, Alex. Child of the Kulaks. Queensland: Queensland University Press, 1997.

Periodicals

Komsomol 'skaia Pravda

Pravda

SSSR Na Stroike/ USSR in Construction

Uchitel'skaia Gazeta

\section{CHILDREN'S LITERATURE AND TEXTBOOKS}

Barto, A. Pervoe Maia. Moskva: Gosudarstvennoe izdatel'stvo, 1928. Vengrov, Natan. Bruni L.

Erdeli, V. G. Geograficheskii Atlas dlia 3-ogo I 5ogo klassov nachal'noi shkolyi, Razrabotan Tsentralnym Nauchno-Issledovatel'slim Institutom Geodezii. TsMOOGA i K pri uchastii uchitelei moskovski shkol Gosudarstvennoi S'emki I Kartogorafii NKVD SSSR.

Nashi Tropiki. Moskva: Molodaia Gvardiia, 1931.

Oktiabr'skie Pesenski. Gorod: Gosudartsvennoe Izdatel'stvo, 1927.

Ryklina, G. Evreiskii Kolkhoz. Moskva: Molodaia Gvardiia, 1931. 


\section{OTHER}

Morozova, M. Ya., E. I. Tikheeva, and L. I. Chulitskaia. Sovremennyi Detskii Sad, Ego Znachenie i Oborudovanie. St. Petersburg: 1920.

The Domostroi: Rules for Russian Households in the Time of Ivan the Terrible, edited and translated by Carolyn Johnston Pouncy. Ithaca: Cornell University Press, 1994.

V.P. Akhmetev, Ikusstvo v butu: 36 tablits: Igrushka, Odezhda (TsI K SSSR I VTsIN, Izvestii ca?)

\section{SECONDARY SOURCES}

“AHA Roundtable: Historians and the Question of Modernity." American Historical Review 116 no. 3 (2011): 631-637.

Benite, Zvi Ben-Dor, "Modernity: The Sphinx and the Historian." 638-652.

Bhambra, Gurminder K. "Historical Sociology, Modernity, and Postcolonial Critique." 653-662.

Chakrabarty, Dipesh. "The Muddle of Modernity.” 663-675.

Anderson, Benedict. Imagined Communities: Reflections on the Origins and the Spread of Nationalism. London: Verso, 1996.

Arendt, Hannah. The Origins of Totalitarianism. New York: Hardcourt Brace, 1976.

Ariès, Philippe. Centuries of Childhood: A Social History of Family Life. Translated by Robert Baldick. New York: Random House, 1962.

Balashov, E.M. "Konturi budushschego grazhdranina: Novye i traditsionnie element v iavleniiakh detskogo soznaniia, 1917-1920-e godi” Nestor 1 (2001): 150-193.

Balashnov, E.M. Shkola v rossiskom obshchestve, 1917-1927, Stanovlenie Novogo Cheloveka. St. Petersburg: Dimitrii Bulanin, 2006.

Balina, Marina. "Creativity Through Restraint: The Beginnings of Soviet Children's Literature." In Russian Children's Literature and Culture, edited by Marina Balina and Larissa Rudova, 3-18. New York: Routledge, 2008.

Ball, Alan. And Now My Soul is Hardened: Abandoned Children in Soviet Russia, 19181930. Berkeley: University of California Press, 1996.

Bassin, Mark. "Nationhood, Natural Regions, Mestorazvitiie: Environmentalist Discourses in Classical Eurasianism." In Space, Place and Power in Modern Russia: Essays in the New Spatial History, edited by Mark Bassin, Christopher Ely, and Melissa K. Stockdale, 49-80. DeKalb: Northern Illinois Press, 2010). 
Baiburin, A.K. Obriadovie formy polovoi identifikatsii detei: Etnicheskie stereotypy muzhskogo i zhenskogo provedeniia, ed. A.k. Baiburin and I.S. Kon (St. Petersburg, 1991).

Bernstein, Francine. The Dictatorship of Sex: Lifestyle Advice for the Soviet Masses. DeKalb: Northern Illinois University Press, 2007.

Bonnell, Victoria. Iconography of Power: Soviet Political Posters Under Lenin and Stalin. Berkeley: University of California Press, 1999.

Borrero, Mauricio. "Communal Dining and State Cafeterias in Moscow and Petrograd, 1917-1921." In Food in Russian History and Culture, edited by Musya Glants and Joyce Toomre, 162-176. Bloomington: Indiana University Press, 1997.

Boym, Svetlana. Common Places: Mythologies of Everyday Life in Russia. Cambridge: Harvard University Press, 1994.

Brooks, Jeffrey. When Russia Learned to Read: Literacy and Popular Literature, 18811917. Princeton: Princeton University Press, 1985.

Brooks, Jeffrey. Thank You, Comrade Stalin!: Soviet Public Culture From Revolution to Cold War. Princeton: Princeton University Press, 2000.

Brown, Kate. A Biography of No Place: From Ethnic Borderland to Soviet Heartland. Cambridge: Harvard University Press, 2004.

Burbank, Jane and Mark Von Hagen. "Coming into the Territory: Uncertainty and Empire.” In Russian Empire: Space, People, Power, 1700-1939, edited by Jane Burbank, Mark von Hagen, and Anatolyi Remnyev, 1-32. Bloomington: Indiana University Press, 2007.

Butueva, T.D. “Fenomen detsvo v traditsionnoi kul'ture mongol'skikh narodov." $\mathrm{PhD}$ diss., Chita State University, 2004.

Caldwell, Melissa L., ed. Food and Everyday Life in the Post-Socialist World. Bloomington: Indiana University Press, 2009.

Canning, Kathleen. Gender History in Practice: Historical Perspectives on Bodies, Class, and Citizenship. Ithaca: Cornell University Press, 2006.

Cavanaugh, Cassandra Marie. Backwardness and Biology: Medicine and Power in Russia and Soviet Central Asia, 1868-1934 (New York: Columbia University Press, 2001.

Chatterjee, Choi and Karen Petrone. "Models of Selfhood and Subjectivity: The Soviet Case in Historical Perspective." Slavic Review 67 (Winter, 2008):967-986. 
Clark, Charles E. Uprooting Otherness: The Literacy Campaign in NEP-Era Russia. Selinsgrove: Susquehanna University Press, 2000.

Conquest, Robert. The Harvest of Sorrow: Soviet Collectivization and the TerrorFamine. Oxford: Oxford University Press, 1986.

Crowley, David and Susan E. Reid, eds. Socialist Spaces of Everyday Life in the Eastern Bloc. New York: Berg Press, 2002.

D'Encausse, Helene Carrere. Decline of an Empire: The Soviet Socialist Republics in Revolt. Translated by Martin Sokolinsky. New York: Newsweek Books, 1980.

De Certeau Michel. The Practice of Everyday Life. Translated by Steven D. Rendell. Berkeley: University of California Press, 1984.

Dowler, Wayne. Classroom and Empire: The Politics of Schooling Russia's Eastern Nationalities, 1860-1917. Montreal: McGill University Press, 2001.

Downs, Laura Lee. Childhood in the Promised Land: Working Class Movements and the Colonies de Vacances in France, 1880-1960. Durham: Duke University Press, 2002.

Edgar, Adrienne Lynn. Tribal Nation: The Making of Soviet Turkmenistan. Princeton: Princeton University Press, 2004.

Engelstein, Laura. The Keys to Happiness: Sex and the Search for Modernity in Fin de Siècle Russia. Ithaca: Cornell University Press, 1992.

Erdiniev, U.E. and K.N. Maksimov, Kalmyki: Istoriko-etnograficheskie ocherki. Elista: Kalmytskoe Knizhnoe Izdatel'stvo, 2007.

Ewing, Thomas. "Ethnicity at School: Educating the "Non-Russian Children of the Soviet Union, 1928-1939.” History of Education (UK) 35 (2006): 499-519.

Ewing, Thomas. "Restoring Teachers to Their Rights: Soviet Education and the 1936 Denounciation of Pedagogy." History of Education Quarterly 41 (2001): 471-93.

Fitzpatrick, Sheila. Everyday Stalinism: Ordinary Life in Extraordinary Times: Soviet Russia in the 1930s. New York: Oxford University Press, 1999.

Fitzpatrick, Sheila. Stalin's Peasants: Resistance and Survival in the Russian Village After Collectivization. Oxford: Oxford University Press, 1994.

Fitzpatrick, Sheila. The Commissariat of Enlightenment: Soviet Organization of Education Under Lunacharsky, October 1917-1921. Cambridge: Cambridge University Press, 1970. Fitzpatrick, Sheila and Alf Ludtke. "Energizing the Everyday: On the 
Breaking and Making of Social Bonds in Nazism and Stalinism.” In Beyond Totalitarianism: Stalinism and Nazism Compared, edited by Michael Geyer and Sheila Fitzpatrick. 266-301. New York: Oxford University Press, 2009.

Fletcher, Anthony and Stephen Hussey, eds. Childhood in Question: Children, Parents and the State. Manchester and New York: Manchester University Press, 1999.

Foucault, Michel. Discipline and Punish: The Birth of the Modern Prison. Translated by Alan Sheridan. New York: Vintage Books, 1997.

Foucault, Michel. "What is Enlightenment?" In The Foucault Reader, edited by Paul Rabinow, 32-50. New York: Pantheon Books, 1984.

Friese, H.G. "Student Life in a Soviet University." Soviet Education, edited by George Kline, 57-78. New York: Columbia University Press, 1957.

Geraci, Robert P. Window on the East: National and Imperial Identities in Late Tsarist Russia. Ithaca: Cornell University Press, 2001.

Goldman, Wendy Z. Soviet Family Policy and Social Life, 1917-1936. Cambridge: Cambridge University Press, 1995.

Gorham, Michael S. Speaking in Soviet Tongues: Language, Culture, and the Politics of Voice in Revolutionary Russia. DeKalb: Northern Illinois University Press, 2003.

Gorsuch, Ann. Youth in Revolutionary Russia: Enthusiasts, Bohemians, Delinquents. Bloomington: Indiana University Press, 2000.

Grenoble, Leonore A. Language Policy in the Soviet Union. Dordrecht, Boston and London: Kluwer Academic Press, 2003.

Halfin, Igal. From Darkness to Light: Class Consciousness and Salvation in Revolutionary Russia. Pittsburgh: Pittsburgh University Press, 2000.

Hamlin, David. The Structures of Toy Consumption: Bourgeois Domesticity and Demand for Toys in Nineteenth-Century Germany." Journal of Social History 35 (2003): 857-69.

Healy, Dan. Bolshevik Sexual Forensics: Diagnosing Disorder in the Clinic and Courtroom. DeKalb: Northern Illinois Press, 2009.

Hellback, Jochen, Revolution on My Mind: Writing a Diary Under Stalin. Cambridge: Harvard University Press, 2006.

Hewitt, Martin. "Biopolitics and Social Policy: Foucault's Account of Welfare." Theory, Culture, and Society 2, 1 (1983): 67-84. 
Hirsch, Francine. Empire of Nations: Ethnographic Knowledge and the Making of the Soviet Union. Ithaca: Cornell University Press, 2005.

Hoffman, David L. and Yanni Kotsonis, eds. Russian Modernity: Politics, Knowledge, Practices. New York: St. Martin's Press, 2000.

Hoffman, David L. Stalinist Values: The Cultural Norms of Soviet Modernity, 19171941. Ithaca: Cornell University Press, 2003.

Holloway, Sarah L. and Gill Valentine, eds. Children's Geographies: Playing, Learning, Living. London and New York: Routeledge, 2000.

Holmes, Larry E. Grand Theatre: Regional Governance in Stalin's Russia, 1931-1941. Lanham: Lexington, 2009.

Holmes, Larry E. Kirov's School No. 9: Power, Privilege, and Excellence in the Provinces, 1933-45. Kirov: Self-published, 2008.

Holmes, Larry. The Kremlin and the Schoolhouse: Reforming Education in Soviet Russia, 1917-1931. Bloomington: Indiana University Press, 1991.

Holmes, Larry E. Stalin's School: Moscow's Model School no. 25, 1931-1937.

Pittsburgh: University of Pittsburgh Press, 1999.

Kelly, Catriona. Children's World: Growing Up in Russia, 1890-1991. New Haven: Yale University Press, 2007.

Kelly, Catriona. Refining Russia: Advice Literature, Polite Culture, and Gender from Catherine the Great to Yeltsin. Oxford: Oxford University Press, 2001.

Kelly, Catriona. "Shaping the Future Race: Regulating the Daily Life of Children in Soviet Russia." In Everyday Life in Early Soviet Russia, edited by Eric Naiman and Christina Kiaier, 256-281. Bloomington: Indiana University Press, 2006.

Kern, Stephen. The Culture of Time and Space, 1880-1918. Cambridge: Harvard University Press, 1983.

Kezer, Zeynep. "Molding the Republican Generation: The Landscapes of Learning in Early Republican Turkey." In Designing Modern Childhoods: History, Space and the Material Culture of Childhood, edited by Marta Gutman and Ning de Conick Smith, 128 -51. New Brunswick: Rutgers, 2008.

Khodakarvsky, Michael. Where Two Worlds Met: The Russian State and the Kalmyk Nomads, 1600-1771. Ithaca: Cornell University Press, 1992. 
Kirschenbaum, Lisa. Small Comrades: Revolutionizing Childhood in Soviet Russia. New York: Routledge, 2001.

Kudriavtsev, V.T. Smysl cheloveskogo detsva i piskhicheskoe razvitie rebenka. Moscow: URAO, 1997.

Kuleshov, E.V. and I.A. Antopova, eds. Detskii sbornik: Stat' i po detskoi literature i antropologii detsva, Moscow, 2003.

Lauglo, Jon. "Soviet Education Policy, 1917-1935: From Ideology to Bureaucratic Control." Oxford Review of Education 14 (1988): 285-299.

Legaretta, Dorothy. The Guernica Generation: Basque Refugee Children of the Spanish Civil War. Reno: University of Nevada Press, 1984.

Loiter, S.M. "Detskii fol'klor v istorii russkoi kultury." Paper presented at the Obrazy Rossii v nauchnom, khudozhestvennom i politicheskom diskursakh-nauchnoi konf. Conference, Petrozvodsk, Russia, September 4-7, 1995.

Ludtke, Alf, ed.The History of Everyday Life: Reconstructing Historical Experiences and Ways of Life. Translated by William Templer. Princeton: Princeton University Press, 1995.

Martin, Terry Dean. Affirmative Action Empire: Nations and Nationalism in the Soviet Union, 1923-1938. Ithaca: Cornell University Press, 2001.

Michaels, Paula A. Curative Powers: Medicine and Power in Stalin's Central Asia. Pittsburgh: University of Pittsburgh Press, 2003.

Morcillo, Aurora. The Seduction of Modern Spain: The female Body and the Francoist Body Politic. Lewisberg: Bucknell University Press, 2010.

Murdoch, Lydia. Imagined Orphans: Poor Families, Child Welfare, and Contested Citizenship in London. New Brunswick: Rutgers University Press, 2006.

Northrup, Douglas. Veiled Empire: Gender and Power in Stalinist Central Asia. Ithaca: Cornell University Press, 2004.

O’Dell, Felicity Ann. Socialisation Through Children's Literature: The Soviet Example. Cambridge: Cambridge University Press, 1978.

Olich, Jacqueline Marie. Competing Ideologies and Children's Books: The Making of a Soviet Children's Literature, 1918-1935. Saarbrucken: Verlag, 2009.

Pan'kin, A.B. Obrazovanie dlia Kalmykov: Istoki, realii, perspektivy. Elista: Kalmytski Gosudarstvennyi Universitet, 1997. 
Petrone, Karen. Life Has Become More Joyous Comrades: Celebrations in the Time of Stalin. Bloomington: Indiana University Press, 2000.

Pipes, Richard. Russia Under the Old Regime. New York: Charles Scribner \& Sons, 1974.

Pipes, Richard. The Formation of the Soviet Union: Communism and Nationalism, 19171923. Cambridge: Harvard University Press, 1970.

Randall, Amy E. The Soviet Dream World of retail Trade and Consumption. New York: Palgrave: MacMillan, 2008.

Ross, Kristen. Fast Cars, Clean Bodies: Decolonization and the Reordering of French Culture. Cambridge: MIT Press, 1998.

Rousseau, J.J. Emile, or On Education. Translated by Allan Bloom. New York: Basic Books, 1979.

Ruane, Christine. "European Fashion in Russia." In Picturing Russia: Explorations in Visual Culture, edited by Valerie Kivelson and Joan Neuberger, 119-123. New Haven: Yale University Press, 2008.

Said, Edward. Orientalism. New York: Pantheon Books, 1978.

Sartikova, E.V. Razvitie shkol'nogo obrazovaniia v Kalmykii v XX veke. Elista: Kalmytstkogo Instituta Gumanitarykh Issledovany, 2008.

Scott, James. Weapons of the Weak: Everyday Forms of Peasant Resistance. New Haven: Yale University Press, 1985.

Sheringham, Michael. Everyday Life: Theories and Practice from Surrealism to the Present. Oxford: Oxford University Press, 2006.

Shevchenko, Olga. Crisis and the Everyday in Postsocialist Moscow. Bloomington and Indianapolis: Indiana University Press, 2009.

Slezkline, Yuri. Arctic Mirrors: Russia and the Small Peoples of the North. Ithaca: Cornell University Press, 1994.

Slezkline, Yuri. "The USSR as a Communal Apartment or How a Socialist State

Promoted Ethnic Particularism." Slavic Review 53 no. 2 (1994): 414-452.

Smith, Allison K. "National Cuisine and Nationalist Politics." Kritika: Explorations in Russian and Eurasian History 10, 2 (2009): 239-260. 
Smith, Allison K. Recipes for Russia: Food and Nation Under the Tsars. DeKalb: Illinois University Press, 2008.

Smith, Michael G. Language and Power in the Creation of the USSR, 1917-1953. Berlin and New York: Mouton de Gruyter, 1998.

Sokolov, S.V. "Schastlivoe detsvo." In Sotsial'naia istoriia, 159-202.

Ezhegodinik:ROSSPEN, 1997.

Spivak, Gaytari Chakravorty. “Can the Subaltern Speak?” In The Post-Colonial studies Reader, edited by Bill Ashcroft, Gareth Griffiths, and Helen Tiffin, 24-28. New York:

Routledge, 1995.

Starks, Tricia. The Body Soviet: Propaganda, Hygiene, and the Revolutionary State. Madison: University of Wisconsin Press, 2008.

Steiner, Evgeny. Stories for Little Comrades: Revolutionary Artists and the Making of Children's Books, Translated by Jane Anne Miller. Seattle: University of Washington Press, 1999.

Sulgina, "Naseledie E.I. Tikheevoi kak tselostnaia pedagogicheskaia sistema." PhD diss. Moskovsky Gumanitarny Universitet, 2007.

Suny, Ronald Grigor. The Soviet Experiment: Russia, the USSR, and the Successor States. New York and Oxford: Oxford University Press, 2011.

Thiel, Markus and Rebecca Friedman. "Introduction: Culture and Narratives of Transnational Belonging." In European Identity and Culture: Narratives of National Belonging. Edited by Rebecca Friedman and Markus Thiel, 1-16. Burlington: Ashgate Publishing, 2012.

Toomre, Joyce. "Food Nationality in Soviet Armenia." In Food in Russian History and Culture, edited by Musya Glants and Joyce Toomre, 195-214. Bloomington: Indiana University Press, 2009.

Vainshtein, Olga. "Russian Dandyism: Constructing a Man of Fashion." In Russian Masculinities in History and Culture, edited by Barbara Evans Clements, Rebecca Friedman, and Dan Healy, 51-75. Houndsmill: Palgrave, 2002. Veidlinger, Jeffrey. The Moscow State Yiddish Theatre: Jewish Culture on the Soviet Stage. Bloomington: Indiana University Press, 2000.

Viola, Lynne, Rebels Under Stalin: Collectivization and the Culture of Peasant Resistance. Oxford: Oxford University Press, 1995. 
VITA

LORAINE DE LA FE

Born, Newark, New Jersey

2001-2005

B.A., History, Magna Cum Laude

Certificate in Pre-Modern Cultures

Florida International University

Miami, Florida

2005

Phi Beta Kappa

Florida International University

Miami, Florida

2005

Award for Outstanding Achievement in History

Florida International University

Miami, Florida

2005-2006

M.A., History

Florida International University

Miami, Florida

Teaching Assistant

Florida International University

Miami, Florida

2008-2013

Doctoral Candidate

Florida International University

Miami, Florida

Adjunct Professor

Florida International University

Miami, Florida

Political and Economic Intern

United States Embassy

Tallinn, Estonia

2009, 2011

Certificate in Russian Language

University of Pittsburgh

Pittsburgh, Pennsylvania 


\section{PUBLICATIONS AND PRESENTATIONS}

Review, Margaret Chowing, Rebellious Nuns: The Troubled History of a Mexican Convent , 1752-1863. Oxford: Oxford University Press, 2006 in The Atlantic Millennium. Vol 9 Summer 2009, pp. 69-70.

"Maridos Ausentes, Mujeres Presentes: Female Household Heads in Spanish Florida, 1784-1812" The Atlantic Millennium. Vol. 8 Spring 2008, pp. 4-19.

"Into the Light: Language and Terror in Revolutionary Kalmykia," Paper presented at the meeting of the Association for Slavic, East European and Eurasian Studies, New Orleans, LA (November 2012)

"Socialization in the Lunchroom: Children's Food Consumption in Early Revolutionary Kalmykia," Paper presented at the Southern Conference for Slavic Studies, Washington, DC, (April 2011),

"Imagining the Young Empire: The Formation of the Soviet Empire through Children's Literature and Propaganda", Paper presented at the Southern Conference for Slavic Studies, Gainesville, FL (March 2010) 